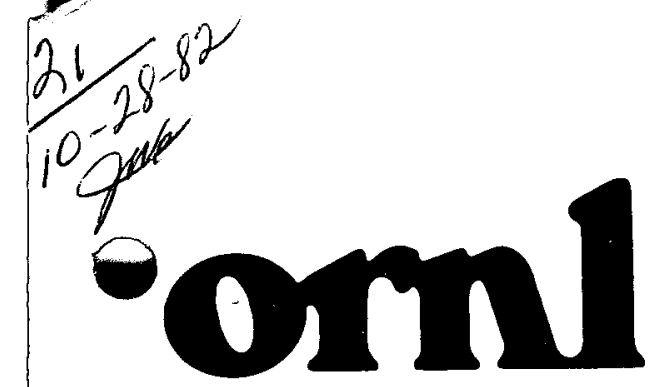

OAK

RIDGE NATIONAL LABORATORY

\section{UNION} CARBIDE

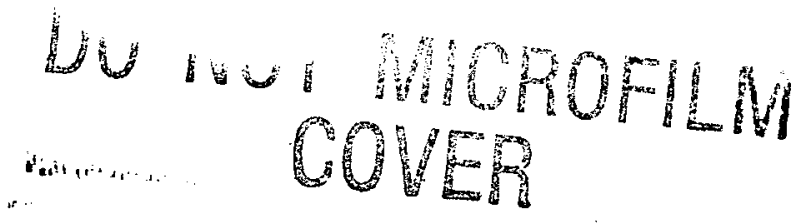

\title{
Preparation of Environmental Analyses for Synfuel and Unconventional Gas Technologies
}

\section{Robert M. Reed}

Elizabeth L. Etnier

Roger L. Kroodsma

Patrick J. Mulholland Kathleen M. Oakes

Robert M. Reed

R. Dickinson Roop
Michael J. Sale Martin Schweitzer John Switek Nancy D. Vaughan Larry D. Voorhees

E. Douglas Waits

\section{ENVIRONMENTAL SCIENCES DIVISION} Publication No. 1843

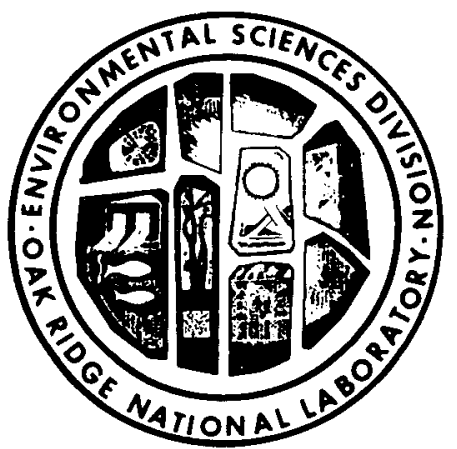

OPERATED BY

UNION CARBIDE CORPORATION FOR THE UNITED STATES DEPARTMENT OF ENERGY 


\section{Printed in the United States of America. Available from National Technical Information Service U.S. Department of Commerce 5285 Port Royal Road, Springfield, Virginia 22161 NTIS price codes-Printed Copy: A10 Microfiche A01}

This report was prepared as an account of work sponsored by an agency of the United States Government. Neither the U nited States Government nor any agency thereof, nor any of their employees, makes any warranty, express or implied, or assumes any legal liability or responsibility for the accuracy, completeness, or usefulness of any information, apparatus, product, or process disclosed, or represents that its use would not inf ringe privately owned rights. Reference herein to any specific commercial product, process, or service by trade name, trademark, manufacturer, or otherwise, does not necessarily constitute or imply its endorsement, recommendation, or favoring by the United States Government or any agency thereof. The views and opinions of authors expressed herein do not necessarily state or reflect those of the United States Government or any agency thereof. 


\section{DISCLAIMER}

This report was prepared as an account of work sponsored by an agency of the United States Government. Neither the United States Government nor any agency Thereof, nor any of their employees, makes any warranty, express or implied, or assumes any legal liability or responsibility for the accuracy, completeness, or usefulness of any information, apparatus, product, or process disclosed, or represents that its use would not infringe privately owned rights. Reference herein to any specific commercial product, process, or service by trade name, trademark, manufacturer, or otherwise does not necessarily constitute or imply its endorsement, recommendation, or favoring by the United States Government or any agency thereof. The views and opinions of authors expressed herein do not necessarily state or reflect those of the United States Government or any agency thereof. 


\section{DISCLAIMER}

Portions of this document may be illegible in electronic image products. Images are produced from the best available original document. 


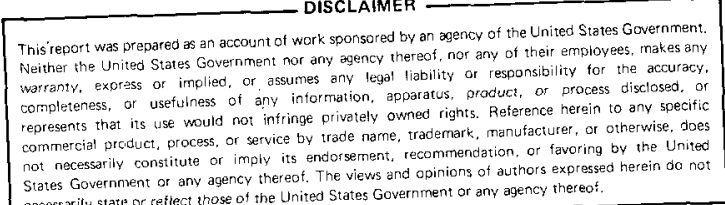

Contract No. W-7405-eng-26

PREPARATION OF ENVIRONMENTAL ANALYSES FOR SYNFUEL AND UNCONVENTIONAL GAS TECHNOLOGIES

Edited by:

Robert M. Reed

Contributors:
Elizabeth L. Etnier ${ }^{1}$

Roger L. Kroodsma

Patrick J. Mulholland

Kath leen M. Oakes

Robert M. Reed

R. Dickinson Roop ${ }^{2}$
Michael J. Sale

Martin Schweitzer ${ }^{2}$

John Switek

Nancy D. Vaughan

Larry D. Voorhees

E. Douglas Waits ${ }^{3}$

ENVIRONMENTAL SCIENCES DIVISION

Publication No. 1843

\footnotetext{
${ }^{1}$ Health and Safety Research Division, Oak Ridge National Laboratory. ${ }^{2}$ Energy Division, Oak Ridge National Laboratory. ${ }^{3}$ Birmingham Southern College, Birmingham, Alabama.
}

Date Published - September 1982

OAK RIDGE NATIONAL LABORATORY

Oak Ridge, Tennessee 37830

operated by

UNION CARBIDE CORPORATION

for the

DEPARTMENT OF ENERGY 


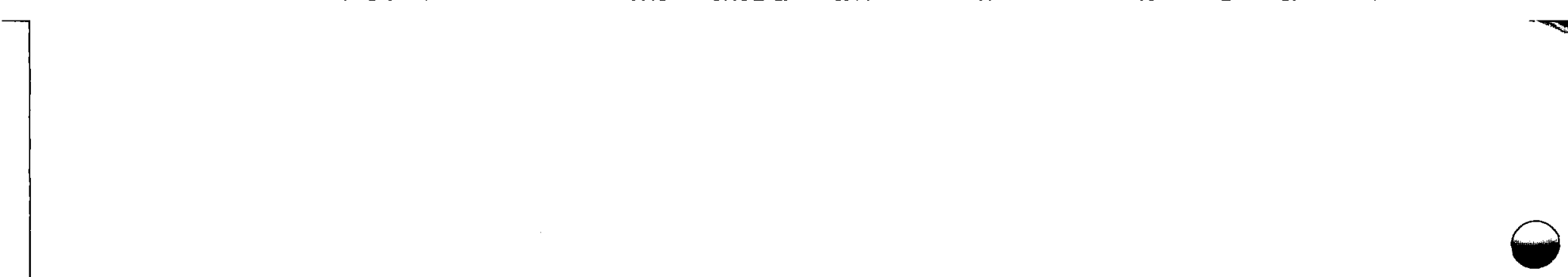

0

$\theta$ 


\section{ACKNOWLEDGMENTS}

This research was supported by the Department of Energy under contract W-7405-eng-26 with Union Carbide Corporation. Sincere appreciation is extended to Glenn F. Cada, James L. Elmore, Carl W. Gehrs, Frank C. Kornegay, James F. McBrayer, Raymond E. Millemann, Martha S. Salk, Frances E. Sharples, Glenn W. Suter, George E. Taylor, and Curtis Travis (Oak Ridge National Laboratory) for their helpful criticisms on early drafts of individual chapters of this report. Paul Kanciruk and Brian Hensley (Oak Ridge National Laboratory) provided draft materials for the chapter on western oil shale. Fredrick A. Rossini and staff of the Technology and Science Program, School of Social Studies, Georgia Institute of Technology, Atlanta, Georgia, prepared draft input for the socioeconomic sections under ORNL subcontract 7802 . 


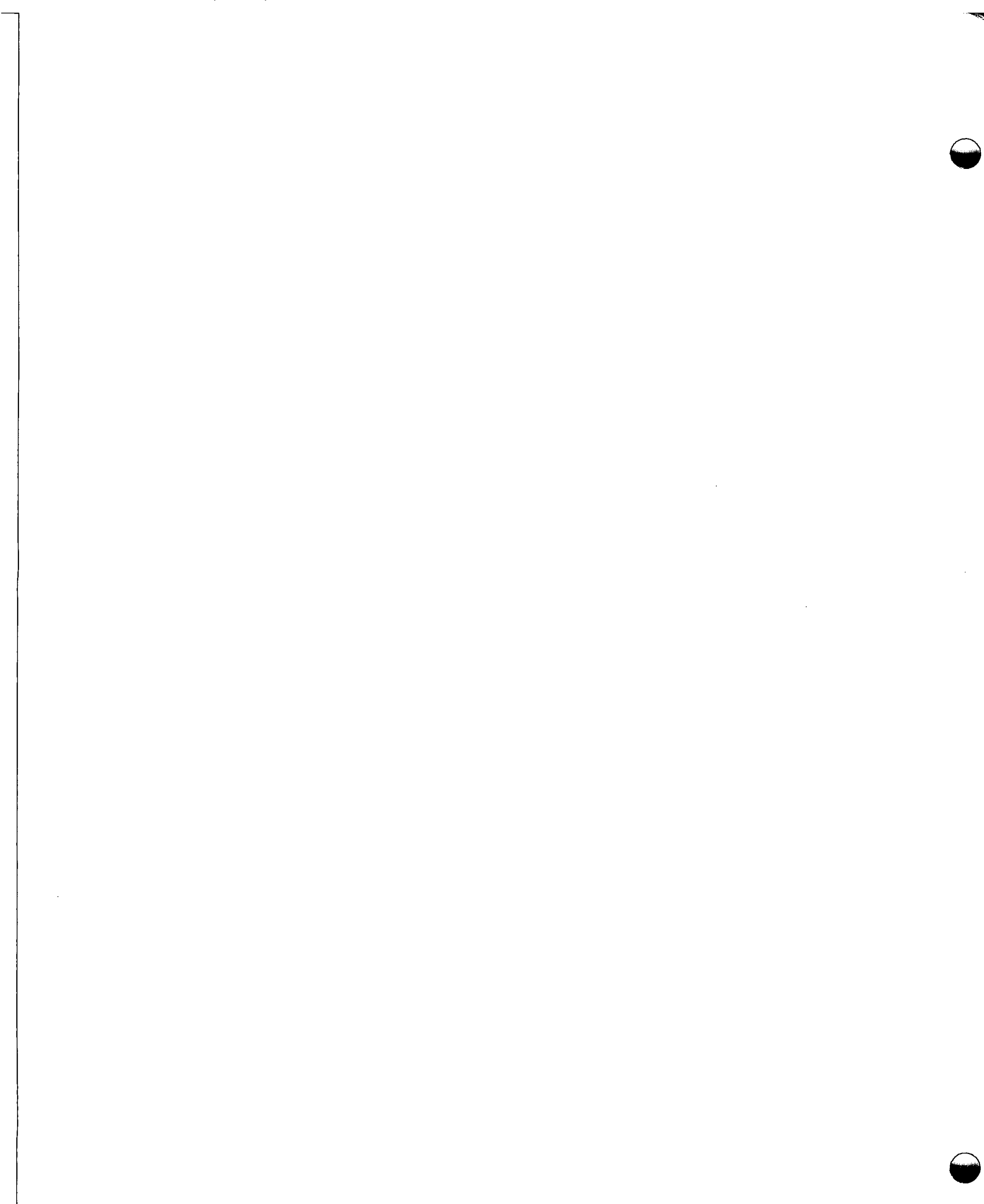

$\bullet$

$\ominus$

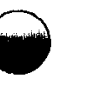

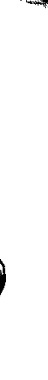

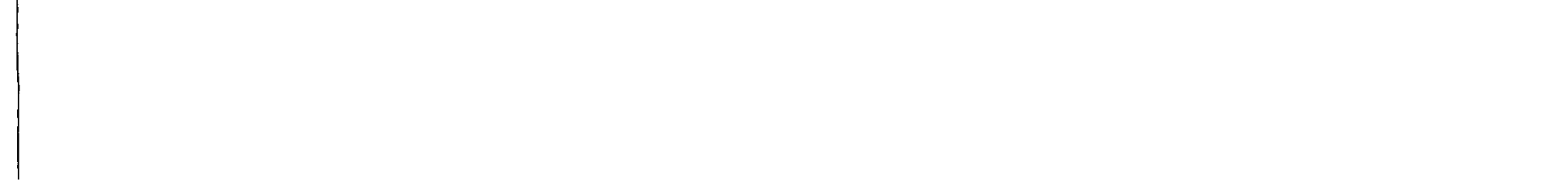




\section{ABSTRACT}

\section{REED, R. M. (ed.). 1982. Preparation of environmental analyses for synfuel and unconventional gas technologies. ORNL-5911 Oak Ridge National Laboratory, Oak Ridge, Tennessee. $212 \mathrm{pp}$.}

Government agencies that offer financial incentives to stimulate the commercialization of synfuel and unconventional gas technologies usually require an analysis of environmental impacts resulting from proposed projects. This report reviews potentially significant environmental issues associated with a selection of these technologies and presents guidance for developing information and preparing analyses to address these issues. The technologies considered are western oil shale, tar sand, coal liquefaction and gasification, peat, unconventional gas (western tight gas sands, eastern Devonian gas shales, methane from coal seams, and methane from geopressured aquifers), and fuel ethanol. Potentially significant issues are discussed under the general categories of land use, air quality, water use, water quality, biota, solid waste disposal, socioeconomics, and health and safety. The guidance provided in this report can be applied to preparation and/or review of proposals, environmental reports, environmental assessments, environmental impact statements, and other types of environmental analyses The amount of detail required for any issue discussed must, by necessity, be determined on a case-by-case basis. 
Page

ACKNOWLEDGMENTS ........................ i i

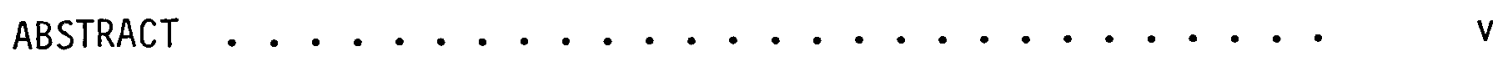

LIST OF TABLES ........................... $x i$

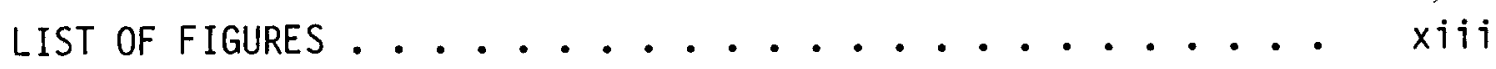

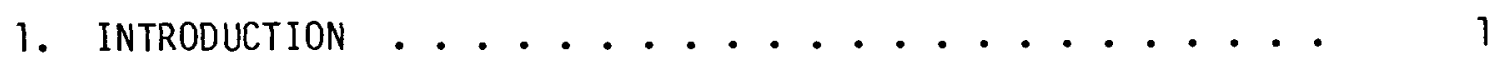

2. WESTERN OIL SHALE (M. J. Sale, E. L. Etnier, M. Schweitzer, and E. D. Waits)

2.1 RESOURCE DESCRIPTION .................... 3

2.2 TECHNOLOGY OVERVIEW .................... 6

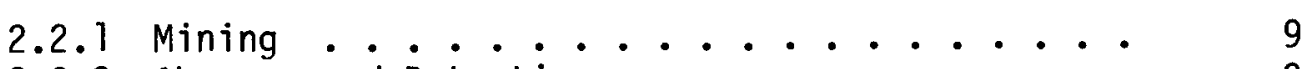

2.2.2 Aboveground Retorting .......... 9

2.2.3 True In Situ Retorting ......... 10

2.2.4 Modified In Situ Retorting ........ 10

2.2.5 Upgrading and Distribution ......... 11

2.3 POTENTIALLY SIGNIFICANT ISSUES . . . . . . . . 11

2.3 .1 Land Use .................... 12

2.3 .2 Air Quality .............. 14

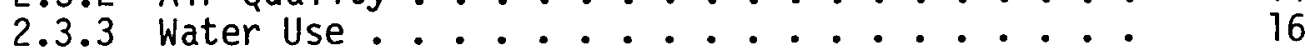

2.3 .4 Water Quality............ 18

2.3 .5 Impacts on Biota ............ 21

2.3 .6 Solid Waste Disposal ........... 22

2.3 .7 Reclamation . . . . . . . . . . . 24

2.3 .8 Socioeconomics . . . . . . . . . . . 25

2.3.9 Health and Safety........... 26

2.4 REFERENCES ............................... 33

3. TAR SAND (K. M. Oakes, M. J. Sale, N. D. Vaughan,

J. Switek, and E. L. Etnier)

3.1 RESOURCE DESCRIPTION ............. 
3.2 TECHNOLOGY OVERVIEW $\ldots \ldots \ldots \ldots$

Page

3.2.1 Surface Mining ............

3.2.2 Separation Processes .........

3.2 .3 Upgrading Processes ..........

3.2 .4 In Situ Extraction ..........

3.3 POTENTIALLY SIGNIFICANT ISSUES . . . . . . . . 43

3.3 .1 Land Use ................. 44

3.3 .2 Air Quality. . . . . . . . . . 45

3.3 .3 Water Use............. 46

3.3 .4 Water Quality ............ 47

3.3.5 Impacts on Biota ............ 49

3.3 .6 Noise ...................... 50

3.3.7 Solid Waste Disposal .......... 51

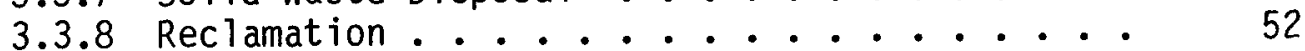

3.3 .9 Socioeconomics ........... 53

3.3.10 Health and Safety............. 54

3.4 REFERENCES . . . . . . . . . . . . 57

4. COAL GASIFICATION AND LIQUEFACTION (M. J. Sale,

R. L. Kroodsma,

M. Schweitzer, and

E. L. Etnier)

4.1 RESOURCE DESCRIPTION . . . . . . . . . . 59

4.2 TECHNOLOGY OVERVIEW .................... 65

4.2 .1 Coal Gasification ........... 65

4.2 .2 Coal Liquefaction ............ 68

4.2.3 Auxillary Processes .......... 71

4.3 POTENTIALLY SIGNIFICANT ISSUES . . . . . . . . 71

4.3 .1 Land Use ................... 71

4.3.2 Air Quality................ 74

4.3.3 Water Use.............. 76

4.3.4 Water Quality............. 79

4.3.5 Solid Waste Disposal .......... 82

4.3 .6 Impacts on Biota ............ 83

4.3.7 Socioeconomics ........... 85

4.3.8 Health and Safety........... 88

4.4 REFERENCES .......................... 91 
5. PEAT (R. M. Reed, L. D. Voorhees, P. J. Mulholland, and M. Schweitzer)

5.1. PEATLAND RESOURCES ................... 97

5.2 TECHNOLOGY OVERVIEW . . . . . . . . . . 102

5.2.1 Peatland Preparation .......... 102

5.2.2 Harvesting ............. 103

5.2.3 Dewatering .............. 104

5.2.4 Use or Conversion........... 105

5.3 POTENTIALLY SIGNIFICANT ISSUES . . . . . . . . 112

5.3.1 Land Use .............. 112

5.3.2 Air Quality.............. 114

5.3.3 Hydrology .............. 115

5.3.4 Water Quality.............. 116

5.3.6 Solid Waste Disposal . . . . . . . . 117

5.3.7 Impacts on Biota ............. 118

5.3.8 Impacts on Unique Ecosystems ........ 120

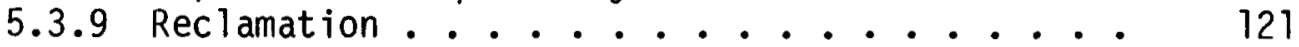

5.3.10 Socioeconomics .................. 122

5.3.11 Health and Safety............ 124

5.4 REFERENCES ......................... 127

6. UNCONVENTIONAL GAS (K. M. Oakes and E. L. Etnier)

6.1 RESOURCE DESCRIPTION . . . . . . . . . . . 133

6.1.1 Western Tight Gas Sands .......... 133

6.1.2 Eastern Devonian Gas Shales . . . . . . . 136

6.1.3 Methane from Coal Seams . . . . . .... 137

6.1.4 Methane from Geopressured Aquifers . . . . 137

6.2 TECHNOLOGY OVERVIEW . . . . . . . . . . . 138

6.2.1 Drilling ............... 138

6.2.2 Advanced Fracturing Methods ......... 140

6.2.3 Well Testing ............. 141

6.2.4 Gas Production ............. . . 142

6.2.5 Tight Gas Sands ............. 142

6.2.6 Devonian Gas Shales........... 143

6.2.7 Coal Seam Methane............. 144

6.2.8 Methane from Geopressured Aquifers . . . . 145 
6.3 POTENTIALLY SIGNIFICANT ISSUES . . . . . . . . 145

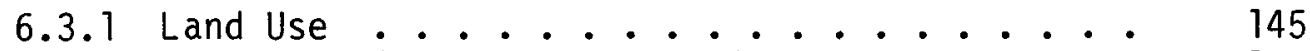

6.3.2 Induced Seismicity and Subsidence...... 147

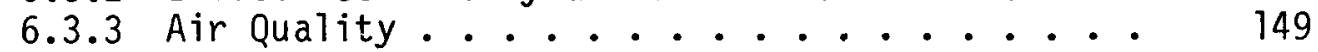

6.3 .4 Water Use ............... 150

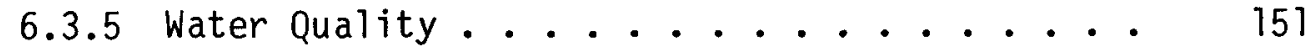

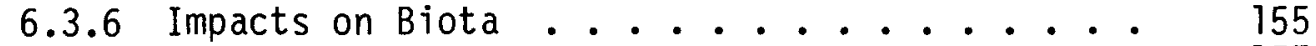

6.3 .7 Noise ............... 157

6.3 .8 Socioeconomics .............. 157

6.3.9 Health and Safety........... 158

6.4 REFERENCES ....................... 161

7. FUEL ETHANOL (R. D. ROOP)

7.1 RESOURCE DESCRIPTION . . . . . . . . . 165

7.1 TECHNOLOGY OVERVIEW ...................... 165

7.1.1 A7cohol Production Process ......... 168

7.1 .2 Raw Materials ........... 171

7.1 .3 Energy Sources ............ 172

7.1 .4 Economic Factors ........... 173

7.2 POTENTIALLY SIGNIFICANT ISSUES . . . . . . . . . 174

7.2 .1 Land Use .................... 174

7.2 .2 Atmospheric Emissions . . . . . . 175

7.2 .3 Stillage Use or Disposal ........ 176

7.2 .4 Waste Water Discharges ......... 178

7.2 .5 Socioeconomics ............. 180

7.2 .6 Health and Safety............... 181

7.3 REFERENCES . . . . . . . . . . . 186

APPENDIX A DESCRIPTION OF THE AFFECTED ENVIRONMENT . . . . 189

APPENDIX B OUTLINE OF AN ENVIRONMENTAL ANALYSIS ...... 193 


\section{LIST OF TABLES}

Table

10 il shale resource estimates in the Green River

Formation ...................

2 Properties of crude shale oil from various retorting processes ................... 7

3 Summary of atmospheric emissions and sources . . . . . 15

4 High priority water quality parameters associated with impacts from oil shale projects ......... . 20

5 World tar sand resources ............. 36

6 Estimated commercial tar sand deposits in the United States................. 36

7 Potential waste constituents from tar sand processing . . 48

8 Mean analytical values for 101 coal types . . . . . . 61

9 Principal chemical conversions involved in coal-derived synfuels production ................

10 U.S. EPA water quality criteria for potential pollutants from coal gasification and liquefaction processes . . . 80

11 World peat resource estimates . . . . . . . . . 98

12 United States peat resources . . . . . . . . . 100

13 Analyses of peat samples . . . . . . . . . 108

14 Estimates of gas-in-place and economically recoverable gas resources from unconventional sources of natural

15 Feedstock advantages and disadvantages . . . . . . . 166

16 Biomass availability for ethanol production . . . . . 167

17 Characterisitics of chemical substances possibly handled in ethanol production . . . . . . . . 182

18 Ethanol plant hazards . . . . . . . . . . . 184

A.1 Information needed to describe the existing environment for the site and its surroundings .......... 
$\theta$ 


\section{LIST OF FIGURES}

Figure

Page

1 Western oil shale deposits ............

2 Generalized oil shale flow diagram . . . . . . .

3 Synthetic crude oil process flow from surface-mined Athabaska tar sand ...............

4 Geographic distribution of coal deposits in the United States .................

5 Alternative processes for synfuel production from coal .

6 Examples of auxillary processes supporting the main coal-derived synfuels production process . . . . . . 72

7 Examples of wastewater reuse alternatives . . . . . 78

8 Distribution of peat resources in the United States, excluding Alaska and Hawaii ............ 101

9 Process design for Minnesota SNG plant . . . . . . 110

10 Unconventional gas resources of the United States . . . 135

11 Typical platform-mounted rotary drilling rig . . . . 139

12 Typical processing steps for conversion of grain to ethanol .................. 


\section{INTRODUCTION}

Interest in alternative energy technologies in the United States has increased considerably within the last five years in response to federal programs for providing industry with financial assistance to build demonstration and commercial facilities. Government initiatives were primarily the responsibility of the U.S. Department of Energy until 1981 when the Synthetic Fuels Corporation took the lead. Although the pace of development has been relatively slow, there is little question that these technologies will make an increasingly important long-term contribution to the nation's energy supply.

The present report reviews environmental issues associated with six energy technologies, namely, western oil shale, tar sand, coal gasification and liquefaction, peat, unconventional gas, and fuel ethanol. Although other technologies and resources could be included in this review, most of the effort in research, development, and commercialization is likely to be focused on these technologies because the resources are the most readily available and/or the technology is either the most promising or farthest along in development.

The purpose of this report is to provide guidance to government agencies, contractors, and industrial applicants for reviewing the environmental effects of proposed projects to comply with the National Environmental Policy Act of 1969. The report identifies potentially significant environmental issues that are likely to be encountered for the six technologies noted above and provides a generic discussion of the types of information and analyses needed to evaluate each issue. In addition, Appendix $A$ discusses the acquisition of information for describing the affected environment and for providing baseline information needed to assess potentially significant impacts.

A major problem in conducting an environmental review of a proposed project is selecting those isssues that are potentialiy significant and that need to be carefully considered in decisions on project approval. If an environmental impact statement is being prepared, a scoping process will be conducted to determine which issues 
need to be considered in detail. If an environmental assessment or some other type of environmental review is being prepared, available information on the proposed project and on the site should be thoroughly reviewed to identify issues that deserve detailed analysis. The guidance contained in this report should assist project and agency staff in preparing and reviewing environmental analyses contained in proposals, environmental reports, and other types of environmental documents. Additional guidance for selecting the pertinent issues to be addressed should come from consultations with appropriate state and federal government offices and from discussions with other interested parties.

Although some of the issues discussed in this guidance document may not be applicable to a particular project, they should all be considered during the environmental review. If certain of these issues are not considered to be relevant to the project in question, the reasons for not providing a detailed analysis should be documented.

The format and content of environmental analyses required by different government agencies vary considerably. Some agencies such as the Nuclear Regulatory Commission have well-defined requirements for the development and submission of environmental information in a document known as an environmental report (10 CFR Part 51). Other agencies, however, have not defined specific requirements but define information and analysis needs on a case-by-case basis. Appendix $B$ of this report presents an outline of an enviromental analysis that is generally consistent with most agency needs. Although this outline defines basic categories of information that are usually needed, each agency should be consulted about specific requirements early in the process. The outline contained in Appendix $B$ will serve as a good basis for these initial discussions. 


\section{WESTERN OIL SHALE}

Michael J. Sale, ${ }^{1}$ Elizabeth L. Etnier, 2 Martin Schweitzer, ${ }^{3}$
and E. Douglas Waits 4

\subsection{RESOURCE DESCRIPTION}

0il shale is a fine-grained sedimentary rock containing a solid hydrocarbon called kerogen. By pulverizing the raw ore and heating it to temperatures greater than $450^{\circ} \mathrm{C}$, the kerogen is decomposed to form hydrocarbon gases and liquids which, upon condensation, yield shale oil. The richest oil shales can contain a petroleum equivalent of $125 \mathrm{~L} / \mathrm{Mg}$ (30 gal 0il/ton shale) or more.

Four types of oil shale are found in the United States: (1) Tertiary period, lacustrine marlstones (not true shales) in the Green River Formation of Colorado, Utah, and Wyoming; (2) marine shales of the late Devonian and early Mississippian periods located across several mideastern and central states, from Michigan and Pennslyvania down to Oklahoma and Texas; (3) Mesozoic deposits of marine shale in Alaska; and (4) small deposits of Permian shales scattered through western Montana, Idaho, Nevada, and southern California.

Because the high-grade oil shale resources in Colorado, Utah, and Wyoming will most likely be the first developed in this country, the guidance is restricted to projects in the western United States. The largest concentration of high-grade oil shale is in the Green River Formation, a 44,000- $\mathrm{km}^{2}$ (17,000-sq. mile) area in northwestern Colorado, northeastern Utah, and southwestern Wyoming. This western oil shale region contains over $90 \%$ of the total estimated U.S. resource, having yields greater than $42 \mathrm{~L} / \mathrm{Mg}$ (10 gal/ton) (Bates and Thoem 1980).

\footnotetext{
IEnvironmental Sciences Division, ORNL.

${ }^{2}$ Health and Safety Research Division, ORNL.

${ }^{3}$ Energy Division, ORNL.

${ }^{4}$ Birmingham Southern College, Birmingham, Alabama.
} 
The oil shales of the Green River Formation are separated into four geologic basins (Fig. 1): the Piceance Basin in west-central Colorado, the Uinta Basin in Utah, the Green River Basin in Wyoming, and the Washaki/Sand Wash Basin in Wyoming and northwestern Colorado. The oil shale resource of the Piceance Basin is significantly greater than that of any of the other basins in terms of yield (Table 1) and thickness of the deposits [greater than $300 \mathrm{~m}(1000 \mathrm{ft})$ in places].

Colorado oil shale typically has an average organic content of $16.5 \%$ embedded within an inorganic, marlstone matrix of dolomite, calcite, and quartz. Because these deposits may be associated with

Table 1. $0 i 1$ shale resource estimates in the Green River Formation

\begin{tabular}{|c|c|c|c|c|}
\hline Grade & $\begin{array}{l}0 i l \text { shale } \\
\text { yield }\end{array}$ & $\begin{array}{c}\text { Piceance } \\
\text { Basin } \\
\text { (Colorado) }\end{array}$ & $\begin{array}{l}\text { Uinta } \\
\text { Basin } \\
\text { (Utah) }\end{array}$ & $\begin{array}{l}\text { Green River, } \\
\text { Washakie, and } \\
\text { Sand Wash basins } \\
\text { (Wyoming and } \\
\text { Colorado) }\end{array}$ \\
\hline & & \multicolumn{3}{|c|}{$\times 10^{9} \mathrm{~m}^{3}\left(10^{9} \mathrm{bb} 1\right)$} \\
\hline I & $\begin{array}{l}63 \text { to } 104 \mathrm{~L} / \mathrm{Mg} \\
\text { (15 to } 25 \mathrm{gal} / \text { ton })\end{array}$ & $\begin{array}{c}191 \\
(1200)\end{array}$ & $\begin{array}{c}51 \\
(321)\end{array}$ & $\begin{array}{c}51 \\
(321)\end{array}$ \\
\hline I I & $\begin{array}{l}104 \text { to } 125 \mathrm{~L} / \mathrm{Mg} \\
(25 \text { to } 30 \mathrm{gal} / \text { ton })\end{array}$ & $\begin{array}{c}97 \\
(607)\end{array}$ & $\begin{array}{l}10 \\
(64)\end{array}$ & $\begin{array}{c}10 \\
(60)\end{array}$ \\
\hline \multirow[t]{2}{*}{ I I I } & $\begin{array}{l}\text { more than } 125 \mathrm{~L} / \mathrm{Mg} \\
\text { (more than } 30 \mathrm{gal} / \text { ton) }\end{array}$ & $\begin{array}{c}56 \\
(355)\end{array}$ & $\begin{array}{c}8 \\
(50)\end{array}$ & $\begin{array}{c}2 \\
(13)\end{array}$ \\
\hline & Total resource & $\begin{array}{c}344 \\
(2162)\end{array}$ & $\begin{array}{c}69 \\
(435)\end{array}$ & $\begin{array}{c}63 \\
(394)\end{array}$ \\
\hline
\end{tabular}

Source: Bates and Thoem (1980). 
ORNL-OWG $81-13948$

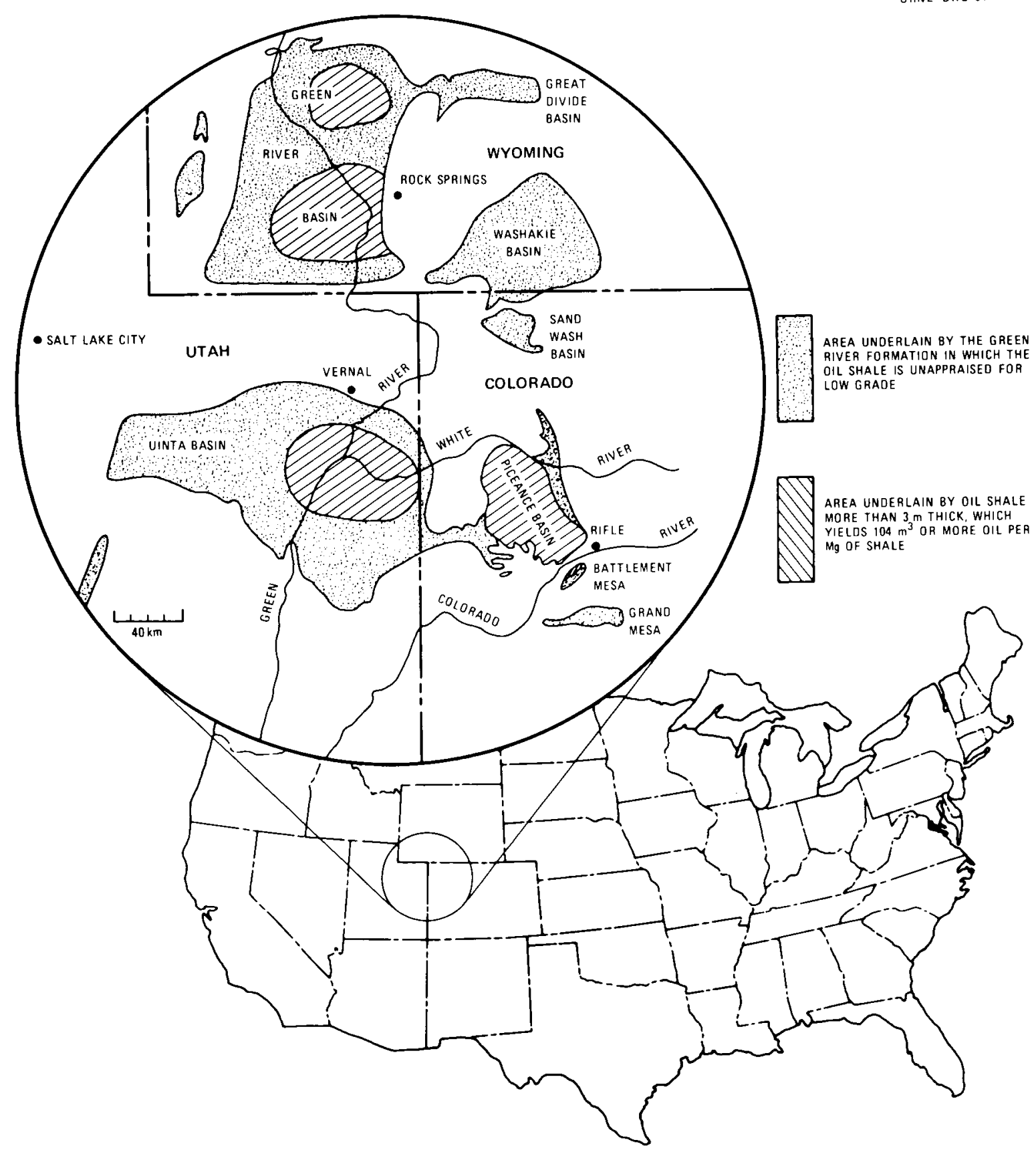

Fig. 1. Western oil shale deposits (modified from OTA 1980). 
sodium-bearing minerals of commercial value, including nahcolite (sodium bicarbonate or baking soda), trona (a hydrated mixture of sodium bicarbonate and sodium carbonate) and dawsonite (dihydroxy sodium aluminum carbonate), oil shale development may include multimineral projects that simultaneously produce shale oil, soda, ash, and alumina (OTA 1980).

This hydrocarbon resource is becoming an increasingly attractive alternative to foreign oil imports and is expected to receive much pressure for development in the near future (Bates and Thoem 1980, NAS 1980, OTA 1980). Depending on economic conditions and world oil prices, the production of synthetic fuels from the western oil shale industry is expected to be in the range of 16,000 to $32,000 \mathrm{~m}^{3} / \mathrm{d}$ $(100,000$ to $200,000 \mathrm{bbl} / \mathrm{d})$ by 1990 and possibly as much as 95,000 $\mathrm{m}^{3} / \mathrm{d}(600,000 \mathrm{bbl} / \mathrm{d})$ by 1995 (Schramm 1980). Because the oil shale deposits in the Green River Formation are rich and accessible, this area is receiving the most attention from the emerging oil shale industry.

\subsection{TECHNOLOGY OVERVIEW}

The production of crude shale oil is based on a pyrolysis reaction in which the kerogen is decomposed into long-chain hydrocarbon molecules. This decomposition process is referred to as retorting and takes $\mathrm{place}$ at temperatures in excess of $450^{\circ} \mathrm{C}$ either in closed reactor vessels above ground or in specially prepared zones of underground deposits. The specific characteristics of shale oil can be quite variable, depending on the conditions under which pyrolysis takes place (Table 2). Raw shale oil, spent shale residue, and pyrolysis gases are the major products that result from the retorting process. Major processing stages common to all oil shale technologies are (Fig. 2): (1) mining and/or preparation of raw shale, (2) retorting, (3) upgrading and refining of the crude shale oil, and (4) transportation of the finished product. One of the principal differences among existing technologies is the type of retort process 
Table 2. Properties of crude shale oil from various retorting processes (OTA 1980)

\begin{tabular}{|c|c|c|c|c|c|c|c|c|c|c|c|c|c|c|c|c|c|}
\hline \multirow{3}{*}{$\begin{array}{l}\text { Retort } \\
\text { Carbon, weight } \% \\
\text { Hydrogen, weight \% } \\
\text { Oxygen, weight \% } \\
\text { Nitrogen, weight \% } \\
\text { Sulfur, weight } \% \\
\text { Carbon/hydrogen ratio }\end{array}$} & \multicolumn{12}{|c|}{ Aboveground processes } & \multicolumn{5}{|c|}{ In situ processes } \\
\hline & \multirow{2}{*}{$\begin{array}{c}\begin{array}{c}\text { Fisher } \\
\text { assay }\end{array} \\
84.59 \\
11.53 \\
-\quad 1.96 \\
0.61 \\
7.34\end{array}$} & \multicolumn{3}{|c|}{ NTU } & \multicolumn{2}{|c|}{$\begin{array}{c}\text { Gas } \\
\text { combustion } \\
\end{array}$} & \multicolumn{2}{|c|}{ TOSCO II } & \multicolumn{2}{|c|}{$\begin{array}{c}\text { Union } 0 \mathrm{i} \text { ? } \\
\text { "A" }\end{array}$} & \multicolumn{2}{|c|}{ Paraho direct } & \multicolumn{3}{|c|}{ Occidental oil shale } & \multicolumn{2}{|c|}{$\begin{array}{c}\text { U.S. Bureau } \\
\text { of Mines } \\
\end{array}$} \\
\hline & & $\begin{array}{l}- \\
- \\
2.20 \\
0.92 \\
-\end{array}$ & $\begin{array}{r}84.67 \\
11.40 \\
1.10 \\
2.10 \\
0.79 \\
7.42\end{array}$ & $\begin{array}{c}84.58 \\
11.76 \\
-1.77 \\
0.76 \\
7.19\end{array}$ & $\begin{array}{r}83.92 \\
11.36 \\
1.67 \\
2.14 \\
0.70 \\
7.39\end{array}$ & $\begin{array}{l}- \\
- \\
- \\
2.12 \\
0.68 \\
-\end{array}$ & $\begin{array}{c}85.1 \\
11.6 \\
0.8 \\
1.9 \\
0.9 \\
7.34\end{array}$ & $\begin{array}{l}- \\
- \\
- \\
1.85 \\
0.67 \\
-\end{array}$ & $\begin{array}{r}84.0 \\
12.0 \\
0.9 \\
2.0 \\
0.9 \\
7.0\end{array}$ & $\begin{array}{r}84.80 \\
11.61 \\
0.90 \\
1.74 \\
0.81 \\
7.30\end{array}$ & $\begin{array}{r}84.90 \\
11.50 \\
1.40 \\
2.19 \\
0.61 \\
7.38\end{array}$ & $\begin{array}{l}- \\
- \\
2.00 \\
0.71 \\
-\end{array}$ & $\begin{array}{r}84.86 \\
11.80 \\
1.13 \\
1.50 \\
0.71 \\
7.19\end{array}$ & $\begin{array}{l}- \\
- \\
- \\
-\end{array}$ & $\begin{array}{l}- \\
- \\
- \\
-\end{array}$ & $\begin{array}{r}84.60 \\
12.08 \\
1.18 \\
1.55 \\
0.59 \\
7.00\end{array}$ & $\begin{array}{l}- \\
- \\
- \\
7.41 \\
0.72 \\
-\end{array}$ \\
\hline $\begin{array}{l}\text { Gravity, }{ }^{\circ} \mathrm{APl} \\
\text { Specific gravity } \\
\text { Pour point, }{ }^{\circ} \mathrm{C}\end{array}$ & $\begin{array}{l}- \\
27\end{array}$ & $\begin{array}{l}19.4 \\
27\end{array}$ & $\begin{array}{l}20.3 \\
-\overline{32}\end{array}$ & $\begin{array}{l}25.2 \\
21\end{array}$ & $\begin{array}{l}19.8 \\
- \\
29\end{array}$ & $\begin{array}{l}21.1 \\
29\end{array}$ & $\begin{array}{l}21.2 \\
0.93 \\
27\end{array}$ & $\overline{0}-93$ & $\begin{array}{l}18.6 \\
27\end{array}$ & $\begin{array}{l}22.7 \\
0.81 \\
16\end{array}$ & $\begin{array}{l}19.3 \\
0.94 \\
29\end{array}$ & $\overline{0}-94$ & $\begin{array}{l}25 \\
0.90 \\
4\end{array}$ & $\begin{array}{l}- \\
-\end{array}$ & $\begin{array}{l}24.3 \\
18\end{array}$ & $\begin{array}{l}28.4 \\
0.89 \\
4\end{array}$ & $\begin{array}{c}28.4 \\
- \\
4\end{array}$ \\
\hline $\begin{array}{l}\text { Arsenic, ppma } \\
\text { Nickel, ppm } \\
\text { Iron, ppm } \\
\text { Vanadium, ppm }\end{array}$ & $\begin{array}{l}- \\
- \\
-\end{array}$ & $\begin{array}{l}- \\
-\end{array}$ & $\begin{array}{l}- \\
-\end{array}$ & $\begin{array}{l}- \\
- \\
-\end{array}$ & $\begin{array}{c}- \\
6.4 \\
108 \\
6 .\end{array}$ & $\begin{array}{l}- \\
- \\
-\end{array}$ & $\begin{array}{r}- \\
6 \\
100 \\
3\end{array}$ & $\begin{array}{l}- \\
- \\
-\end{array}$ & $\begin{array}{c}- \\
6 \\
55 \\
7.5\end{array}$ & - & $\begin{array}{c}19.6 \\
2.5 \\
71.2 \\
0.37\end{array}$ & $\begin{array}{l}- \\
-\end{array}$ & $\begin{array}{l}- \\
- \\
-\end{array}$ & $\begin{array}{l}- \\
- \\
-\end{array}$ & $\begin{array}{l}- \\
- \\
-\end{array}$ & $\begin{array}{l}- \\
- \\
-\end{array}$ & $\begin{array}{l}- \\
- \\
-\end{array}$ \\
\hline $\begin{array}{l}\text { Distillation, } \\
\text { volume \% } \\
50{ }^{\circ} \mathrm{C} \\
100{ }^{\circ} \mathrm{C} \\
2000{ }^{\circ} \mathrm{C} \\
3000{ }^{\circ} \mathrm{C} \\
400{ }^{\circ} \mathrm{C} \\
5000{ }^{\circ} \mathrm{C} \\
6000{ }^{\circ} \mathrm{C} \\
7000{ }^{\circ} \mathrm{C} \\
800{ }^{\circ} \mathrm{C} \\
900{ }^{\circ} \mathrm{C} \\
9500 \mathrm{C}\end{array}$ & $\begin{array}{r}163 \\
221 \\
270 \\
- \\
346 \\
363 \\
374 \\
- \\
- \\
-\end{array}$ & $\begin{array}{r}25 \overline{6} \\
293 \\
- \\
- \\
354 \\
367 \\
- \\
- \\
-\end{array}$ & $\begin{array}{l}- \\
- \\
- \\
- \\
- \\
- \\
- \\
-\end{array}$ & $\begin{array}{l}- \\
- \\
- \\
- \\
- \\
- \\
- \\
-\end{array}$ & $\begin{array}{l}192 \\
226 \\
276 \\
319 \\
359 \\
395 \\
429 \\
463 \\
502 \\
554 \\
593\end{array}$ & $\begin{array}{r}229 \\
258 \\
309 \\
353 \\
394 \\
431 \\
463 \\
492 \\
529 \\
574 \\
-\end{array}$ & $\begin{array}{r}93 \\
135 \\
210 \\
260 \\
327 \\
371 \\
413 \\
454 \\
493 \\
- \\
-\end{array}$ & $\begin{array}{r}182 \\
249 \\
316 \\
366 \\
416 \\
460 \\
502 \\
549 \\
- \\
-\end{array}$ & $\begin{array}{r}199 \\
241 \\
296 \\
338 \\
377 \\
413 \\
443 \\
527 \\
- \\
- \\
-\end{array}$ & $\begin{array}{r}38 \overline{-} \\
51 \overline{6} \\
-\end{array}$ & $\begin{array}{r}27 \overline{1} \\
316 \\
360 \\
399 \\
432 \\
449 \\
- \\
- \\
- \\
-\end{array}$ & $\begin{array}{r}277 \\
327 \\
360 \\
396 \\
429 \\
460 \\
488 \\
527 \\
560 \\
-\end{array}$ & $\begin{array}{r}22 \overline{-} \\
31 \bar{\sigma} \\
37 \overline{1} \\
- \\
410 \\
- \\
49 \overline{3} \\
-\end{array}$ & $\begin{array}{l}204 \\
238 \\
271 \\
299 \\
327 \\
360 \\
379 \\
407 \\
441 \\
488 \\
566\end{array}$ & $\begin{array}{r}207 \\
- \\
- \\
31 \overline{6} \\
- \\
- \\
4 \\
4 \overline{-} \\
538\end{array}$ & $\begin{array}{r}19 \overline{4} \\
207 \\
173^{\mathrm{b}} \\
191^{\mathrm{b}} \\
213^{\mathrm{b}} \\
240^{\mathrm{b}} \\
276^{\mathrm{b}} \\
- \\
-\end{array}$ & $\begin{array}{r}16 \\
327 \\
342 \\
352 \\
361 \\
371 \\
389 \\
409 \\
432 \\
464 \\
490\end{array}$ \\
\hline
\end{tabular}

aparts per million.

bVacuum distillation at $40 \mathrm{~mm}$ of mercury. All other results are from atmospheric distillation. 


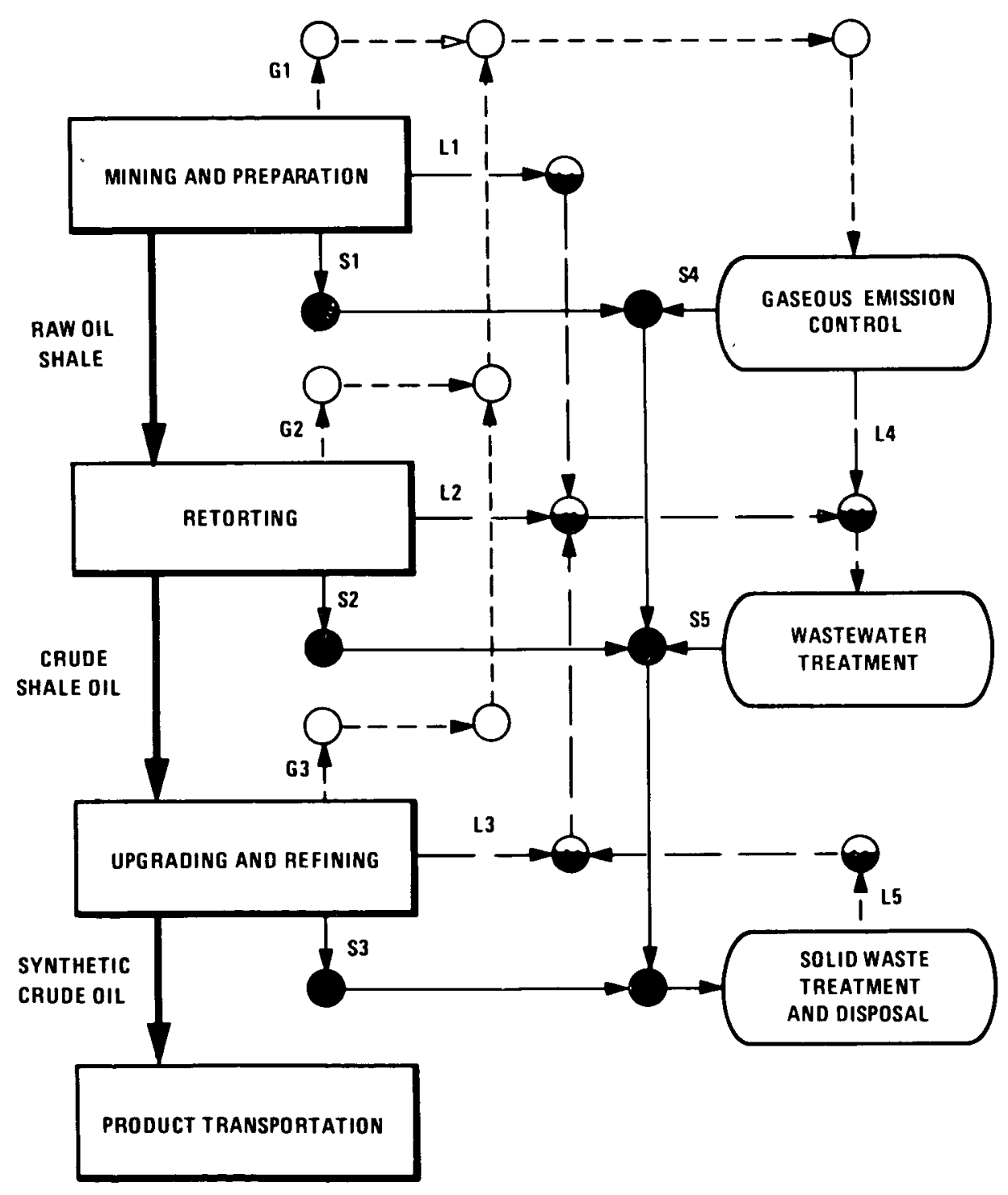

ORNL-DWG 81-14055 ESD

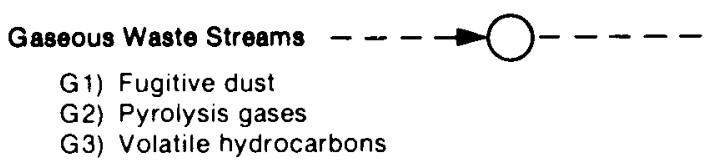

2) Coproduced water, boiler feed water, retort condensates

L3) Process condensates, coker and hydrotreater

L4) Blowdown, gas condensates, cooling tower blowdown

L5) Leachate and surface runoff, excess mine drainage

\section{Solids Waste Sources}

51) Excess overburden, unprocessed oil shale fines

S2) Spent shale and coke residues

S3) Spent catalysts

44) Blowdown solids

S5) Sludges from water treatment processes

Fig. 2. Generalized oil shale flow diagram. 
used. Three alternative approaches have been developed: aboveground retorting (AGR), true in situ (TIS) processing, and modified in situ (MIS) processing. The in situ processes are advantageous in that they require much less mining and transport of the raw shale. At the present stage of develoment, however, the TIS and MIS technologies are less efficient and more unpredictable than the AGR approach.

\subsubsection{Mining}

Mining activities associated with western oil shale development are likely to become some of the largest in the world. Both surface and underground mining will be required. In the Piceance Basin, $80 \%$ of the high-grade shale lies in deep deposits in the central part of the basin and, therefore, will require some type of underground mining methods or in situ extraction (Bates and Thoem 1980). Potential MIS and AGR oil shale mining operations required to produce $8000 \mathrm{~m}^{3} / \mathrm{d}$ $(50,000 \mathrm{bbl} / \mathrm{d})$ from $125-\mathrm{L} / \mathrm{Mg}$ deposits would require mining shale at the rate of 26,000 to $64,000 \mathrm{Mg} / \mathrm{d}(29,000$ to 70,000 ton/d), respectively. As the incentive to produce domestic shale oil increases, mining operations of even greater size will be contemplated.

\subsubsection{Aboveground Retorting (AGR)}

The AGR process relies on shale ore extraction by conventional surface or underground mining techniques. Open-pit mining may be suitable for relatively shallow deposits, while deep, high quality deposits may be profitably mined using the room and pillar underground mining technique. The mined ore is moved to the surface retorting facility where it is crushed and sized. The retorting process heats the ore to temperatures of at least $450^{\circ} \mathrm{C}$ to bring about pyrolysis of the kerogen and the production of $0 i 1$ and gas. This heating process may be either direct, creating a combustion zone within the retort itself, or indirect, using an external reactor or combustor to transfer heat to an internal retort (e.g., indirect heating in the TOSCO II AGR retort which uses hot ceramic balls to transfer heat into the reactor). Once $0 i 1$ and/or gas are obtained from the retort, they are 
usually upgraded and transported to a refinery for further processing. Recovery efficiencies as high as 100\% have been demonstrated using AGR (OTA 1980). Commercial-scale equipment and operations, however, have yet to be successfully developed. The major disadvantage anticipated for using the AGR approach is the extensive surface disturbance caused by mining and disposal of shale wastes. Approximately $85 \%$ of the total weight of the initial shale remains after retorting and cannot be returned in its entirety to the mines from which it was extracted.

\subsubsection{True In Situ (TIS) Retorting}

The TIS approach heats the shale underground and recovers the oil and gas produced from holes drilled into the shale formation. The technique requires a minimum of conventional mining operations but instead utilizes natural or man-made fractures to provide access for injecting hot fluids or igniting a portion of the bed to provide heat for pyrolysis. Fracturing ("rubbling") of the shale may be necessary to promote permeability and fluid flow. Dewatering may also be required to remove groundwater prior to beginning the TIS operation.

The TIS is the least developed of the three technologies. Experimental results indicate that TIS will produce the lowest yields of the three retort processes unless significant advances can be made. A major advantage of the TIS process is that surface disturbance from mining and raw shale waste disposal are limited or nonexistent. Subsidence and potential contamination of groundwater are two potential areas of concern for TIS projects.

\subsubsection{Modified In Situ (MIS) Retorting}

The MIS technology relies on limited mining and underground explosions to reduce a section of an oil shale formation to rubble. Twenty to forty percent of the shale in the MIS retort zone is removed by underground mining to provide a void space for expansion of rubblized shale. Compared to the undisturbed oil shale, the increased surface area of this rubble zone allows relatively efficient retorting to occur. Access holes for air, exhaust, and $0 i l$ and gas extraction 
are drilled into the rubble site. A combustible gas is introduced through an access hole to ignite the shale, and subsequent combustion is supported by hydrocarbons released from the shale during pyrolysis. once combustion occurs, it soon becomes spontaneous and the flame front moves through the rubble, retorting the oil shale as it passes. 0il collects at the bottom of the rubble and is then pumped to the surface.

A major problem with MIS retorting is the limited control of in situ pyrolysis reactions that is achieved once combustion is initiated. Available control variables are the inflow of combustion gases, the pattern of rock fractures created in rubblization, and the size of the void space created in initial mining. Recovery efficiency is much lower compared to AGR because pyrolysis is incomplete and pillars within the shale deposit are left undisturbed for support. In situ project efficiencies can be increased when AGR is used to process the shale removed to provide the void spaces.

\subsubsection{Upgrading and Distribution}

Although the characteristics of raw shale oil (Table 2) depend on the recovery technology used, upgrading will be necessary because raw shale oil has a high pour point, viscosity, and nitrogen and oxygen content. The shale oil may either be converted to an intermediate product suitable for pipeline transport to offsite refineries, or it may be refined directly into finished products such as gasoline, diesel oil, aviation fuels, or heavy fuel oil. One reason for the initial upgrading of the crude shale oil is to remove undesirable constituents such as sulfur or heavy metals that can poison the catalysts used in the refinery process. Western shale oil is a desirable source of refinery feedstocks because it has a relatively low boiling point and contains lower residuals than either Alaskan North Slope or Arabian light crude oils.

\subsection{POTENTIALLY SIGNIFICANT ISSUES}

The environmental analysis should describe and analyze potentially significant environmental impacts associated with construction, mining, 
operation, and reclamation of proposed oil shale projects. In addition, information gathered on the affected environment should be reviewed to determine if any additional significant or controversial issues are apparent. For example, the review of background information on the affected environment may show that an historic site, portions of a 100-year floodplain, or a site of religious significance to local Indian tribes is present on the project property. In such a situation, the information content and analysis of the issue should be expanded.

The issues discussed in the following sections are most likely to be significant for oil shale projects and should be carefully reviewed.

\subsubsection{Land Use}

The development of western oil shale resources may be hindered by the complex pattern of federal, state, private, and Indian land ownership and mining claims (OTA 1980, NAS 1980, U.S. DOI 1973). Nearly $80 \%$ of the deposits in Colorado, Utah, and Wyoming lie beneath federal lands. Most of the private mining claims scattered throughout the region are located on small, noncontiguous tracts in areas having relatively low-grade resources. Full-scale commercialization is currently being delayed for a variety of reasons, including litigation over conflicting mining rights, lack of adequate economic incentives, negotiations for private or public land exchanges which could allow industry access to more desirable oil shale tracts, and uncertainties over design and productivity of available technologies.

Land use in the oil shale region is somewhat restricted by the rugged terrain and low annual precipitation. Most of the land is used for rangeland, watershed protection, recreation, wildlife, hay, and limited gas production. Commercial-scale oil shale development is likely to generate land-use conflicts when range, timber, mineral, and recreational lands are disrupted by mining, processing, and waste disposal operations, by the development of associated urban areas, and by secondary developments.

The amount of land surface disrupted by a commercial-scale oil shale operation will vary depending on the mining and retorting 
technology used and the approach adopted for disposing of spent shale. Surface mining and AGR operations are likely to have the greatest impact because the areas disrupted by mining and waste disposal will be large (OTA 1980). A facility using surface mining, retorting, and surface disposal of spent shale could disrupt hundreds to thousands of hectares of land.

The presence of significant archaeological and historic sites, Indian lands, national monuments, and other scenic and recreation areas either on or near the potential oil shale lands may conflict with development of specific projects. The aesthetic impacts of oil shale development are also likely to be severe because the oil shale region is rural and relatively undeveloped.

In addition to general baseline information, the analysis of land-use conflicts should provide detailed information on:

- present and planned land use for the project site and surrounding areas;

- present and projected land ownership;

- national parks, landmarks, and monuments, recreation areas, existing or proposed wilderness areas, and scenic, historic, or archaeologic sites in the vicinity of the project;

- visibility of the proposed site and associated facilities from public use areas, such as trails, canyon over looks, and picnic/camping areas; and

- Indian-owned lands and areas sacred to local Indian tribes.

A land-use map showing the potential routes for heavy equipment and construction traffic associated with the project should be provided. The possibility of adverse effects from increased traffic through sensitive land-use areas (e.g., Indian lands or wilderness areas) should be addressed. 


\subsubsection{Air Quality}

Atmospheric emissions will be generated from mining, processing, retorting, and waste disposal (Table 3 ). Because the mining operations will be novel only with respect to scale, control of particulate and dust emissions from raw shale mining, blasting, conveying, crushing, and screening can draw on experience with existing practices. The environmental analysis should characterize and quantify, to the extent possible, fugitive dust emissions from all sources (including disposal of spent shale) and describe plans for controlling fugitive dust.

Spraying rates should be carefully controlled because the use of water sprays along with other wetting agents to control fugitive dust will contribute to overall water needs of the project and may contribute to water pollution problems by increasing runoff and leaching. If recycled water is used in dust control, the chemical composition of the water becomes another potential problem in terms of uptake of toxic chemicals by vegetation and contamination of runoff waters. The plans for fugitive dust control should include a discussion of the use of water sprays and wetting agents and should address the problems of controlling contaminated runoff and uptake of toxic chemicals by vegetation.

Stack emissions will include particulates, sulfur oxides, oxides of nitrogen, hydrocarbons, and carbon monoxide as well as organic compounds such as polycyclic aromatic hydrocarbons (PAHs). Control of these pollutants is common to other industries (e.g., oil refineries), but the introduction of new pollutant sources into an area of the western United States with good ambient air quality will require careful analysis.

Individual commercial-scale plant emissions can probably be controlled by state-of-the-art pollution abatement technology. However, the cumulative impacts of a number of oil shale facilities, as well as other emission sources, may affect nearby Class I air quality regions. The cumulative impacts of nearby energy or mineral developments may severely limit the availability of Prevention of Significant Deterioration (PSD) increments and constrain the development of the oil shale resource. 
Table 3. Summary of atmospheric emissions and sources. ${ }^{a}$

\begin{tabular}{|c|c|c|c|c|c|c|c|c|c|}
\hline Atmospheric emissions & $\frac{n}{g} \frac{0}{ \pm}$ & 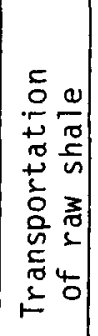 & 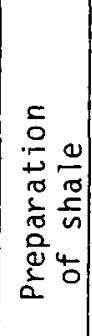 & 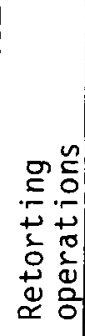 & 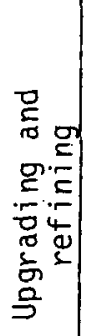 & 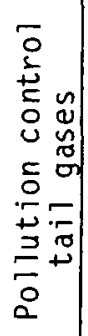 & 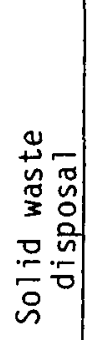 & 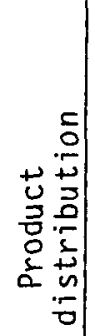 & 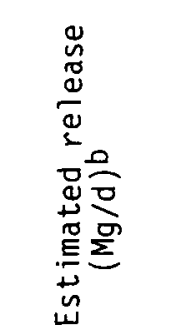 \\
\hline Particulates & & & & & & & & & $0.3-7.8$ \\
\hline Fugitive dust & * & * & * & + & & & * & + & \\
\hline Soot and ash & & & & * & + & + & & & \\
\hline Spent shale dust & & & & + & & & * & & \\
\hline Carbon monoxide $(\mathrm{CO})$ & + & + & & * & * & + & + & + & $0.4-1.9$ \\
\hline Nitrogen oxides $\left(\mathrm{NO}_{\mathrm{x}}\right)$ & + & + & & * & * & + & + & + & $6.2-64.0$ \\
\hline Sulfur dioxide $\left(\mathrm{SO}_{2}\right)$ & + & + & & * & * & + & + & + & $0.2-58.0$ \\
\hline Hydrocarbons & + & + & & * & * & + & + & + & $0.3-28.0$ \\
\hline Mercury & + & & & + & & & & & \\
\hline Lead & + & & & + & & & & & \\
\hline Silica & + & + & + & & & & & & \\
\hline Trace elements & & & & & & & & & \\
\hline$(\mathrm{Ni}, \mathrm{Cr}, \mathrm{Fe}, \mathrm{Mo}$, etc. $)$ & & & & * & & & + & & \\
\hline Hydrogen sulfide & & & & * & & + & & & \\
\hline Organo-sulfide & & & & & & + & & & \\
\hline
\end{tabular}

$a_{+}=$minor source; $*$ = major source.

bSOURCE: Bates and Thoem (1980). 
General background information should be expanded to provide specifics on the following:

- all affected Air Quality Control Regions (AQCRs), with special emphasis on Class I areas;

- local meteorology (local airport data and onsite measurements), emphasizing those features that affect the dispersion of anticipated emissions;

- local air quality (U.S. EPA and/or state monitoring data; monitoring data from nearby facilities, as available; onsite baseline monitoring data, if required by state or federal agencies);

- proposed use of air pollution control devices, including an estimate of efficiency and downtime;

- characterization of atmospheric emissions and quantification of emission rates from both construction and operation activities;

- modeling of atmospheric dispersion;

- analysis of the effects of the project on visibility to the extent required by State Implementation Plans;

- identification of unknowns and uncertainties associated with the characterization and dispersion analysis of atmospheric emissions;

- identification of sensitive areas, both on and off the site (e.g., sensitive plant species or vegetation types) that may be affected by atmospheric emissions; and

- proposed air quality monitoring program.

\subsubsection{Water Use}

The availability of adequate water supply can be a significant limiting factor in the development of all types of energy resources in the arid, western United States. Therefore, careful consideration of interactions between project development and local or regional water resources must be a specific component of any environmental analysis for oil shale projects. Water quantity requirements included in a 
description of project construction and operation should be expanded toindicate the resource needs of various consumptive and nonconsumptive water uses. Plans for meeting these water needs should then be identified in the form of a comprehensive water management plan. Among the water-use categories that should be quantified are the following (Kinney et al. 1979):

- mining and delivery of raw shale,

- crushing and preparation of raw shale,

- retorting processes,

- upgrading processes,

- gas cleanup and pollution control processes,

- disposar of spent shale,

- reclamation and revegetation,

- $\quad$ power generation, and

- domestic consumption.

Water management plans should specify the sources for satisfying the requirements of each water-use category. More specifically, information should be provided to identify:

- surface water sources to be utilized, including descriptive hydrology of the watershed and planned withdrawal rates;

- groundwater sources to be utilized, including aquifer description and safe yields;

- dependence of project water sources on the construction of related water development projects;

- interrelationships between groundwater sources utilized and surface water, including other aquifers or recharge zones that might be affected by the project; and

- institutional, legal, and political arrangements involved in obtaining water supplies, including documentation of appropriate water rights, entitlements, or permits. 
In considering institutional, legal, and political aspects of obtaining water, attention should be given to the quantity and projected sources of water over the estimated life of the project. State and federal water law governing the use of water in the Upper Colorado River Basin should be described in relation to the proposed project (OTA 1980). Specific institutional and legal arrangements for obtaining water from each of the designated sources should be specified. The availability of sufficient water supplies over the life of the project should be estimated. Where high and low estimates indicate a potential shortage, the competing uses for the water (e.g., irrigation, urban use, and industrial use), with their priorities and constituencies, should be described. Discussion of the legal, institutional, and economic arrangements for allocating scarce water, as well as developing additional sources (e.g., through interbasin diversion), should be included. In summary, it is necessary to describe both the societal and the physical arrangements for retaining water supplies over the life of the project.

The quality of water sources should be described to ensure that it meets project requirements. Necessary water treatment should be described. The project proponent should evaluate all opportunities for water recycling and conservation within the project design and should emphasize the consideration of these alternatives. Zero-effluent operations that maximize water reuse are desirable, both in terms of reducing impacts on ambient water quality and conservation of regional water resources (Bates and Thoem 1980).

\subsubsection{Water Quality}

Potential degradation of ambient surface or groundwater quality is another important issue associated with oil shale development. Even projects with zero-effluent designs under normal operating conditions should consider the implications of effluents released during abnormal operating periods (e.g., startup, shutdown, or equipment failures) or peak runoff events (Bates and Thoem 1980). Wastewater collection, treatment, and disposal, as well as any pollution mitigation plans, 
should be described in detail to ensure that all possible efforts are made to minimize the likelihood of adverse impacts on water quality. Table 4 summarizes the important constituents and sources of wastewater effluents from oil shale projects.

The effects of oil shale projects on groundwater resources $c$ an be direct or indirect. Direct effects include water quality changes caused when reinjection is used as a disposal method for mine dewatering effluents or by leachate from surface water percolation through solid waste disposal areas or MIS rubble zones. Indirect effects include the results of disrupting relatively impermeable shale layers, changing the interaction between existing aquifers of different water qualities. Even though these effects may involve questions beyond the present knowledge of the groundwater sciences, they should be addressed in project planning. Monitoring programs should be designed for early detection of significant impacts (Slawson 1979).

Special attention should be paid to describing the fate of toxic compounds known to have potentially high concentrations in effluents (Bates and Thoem 1980, Kinney et a1. 1979). The environmental analysis should compare the expected composition of toxic compounds in receiving systems to baseline conditions and to applicable state and/or federal water quality standards. For a description of surface runoff and leachates, the chemical composition of raw and spent oil shales should be described, and the results of studies on leaching from these materials should be presented. It is desirable that composition and quantities of raw materials and effluents be described in sufficient detail to account for approximate material balances through a process flow diagram.

Guidance provided by the U.S. Environmental Protection Agency for Best Available Technologies and Best Management Practice in oil shale development suggests the following (Bates and Thoem 1980):

- no discharge of retort or oily process water,

- reinjection of mine water into aquifers having similar water quality, 
Table 4. High-priority water quality parameters associated with impacts from oil shale projects

\begin{tabular}{|c|c|c|c|c|c|c|}
\hline Parameters & 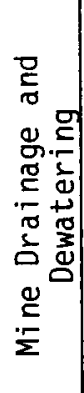 & 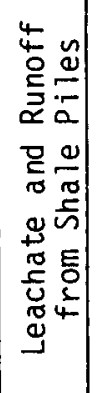 & 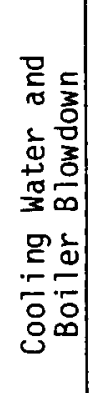 & 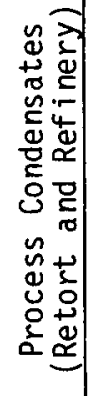 & 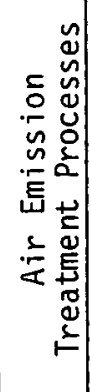 & 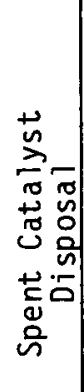 \\
\hline $\begin{array}{l}\text { Alkalinity } \\
\text { Aluminum (dissolved and total) } \\
\text { Ammonia } \\
\text { Arsenic } \\
\text { Boron } \\
\text { Cadmium } \\
\text { Calcium } \\
\text { Chemical oxygen demand } \\
\text { Chloride } \\
\text { Chromium } \\
\text { Conduct ivity } \\
\text { Copper } \\
\text { Cyanide } \\
\text { Fluoride } \\
\text { Hardness } \\
\text { Iron } \\
\text { Lead } \\
\text { Magnesium } \\
\text { Manganese } \\
\text { Mercury } \\
\text { Molybdenum } \\
\text { Nickel } \\
\text { Nitrate } \\
\text { Oil and grease } \\
\text { pH } \\
\text { Phenols (total phenolics) } \\
\text { Polycyclic aromatic hydrocarbons (PAH) } \\
\text { Potassium } \\
\text { Selenium } \\
\text { Sodium } \\
\text { Sulfate } \\
\text { Sulfide } \\
\text { Temperature } \\
\text { Total dissolved solids (TDS) } \\
\text { Total suspended solids (TSS) } \\
\text { Turbidity } \\
\text { Zinc } \\
\text { Vanadium }\end{array}$ & $\begin{array}{l}\star \\
\text { * } \\
\text { * }\end{array}$ & 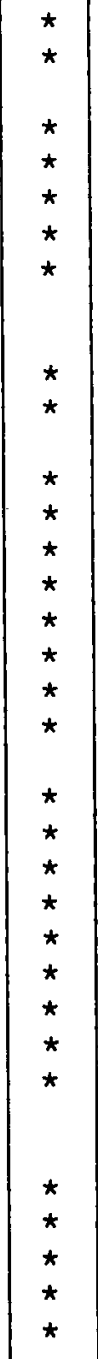 & $\begin{array}{l}\star \\
\star\end{array}$ & $\begin{array}{l}\text { * } \\
\text { * } \\
\text { * }\end{array}$ & $\begin{array}{l}\star \\
\star\end{array}$ & $\begin{array}{l}\star \\
\star\end{array}$ \\
\hline
\end{tabular}

SOURCE: Kinney et al. (1979). 
- diversion of surface runoff from process areas,

- collection of runoff from disturbed areas into sedimentation ponds,

- collection and containment of leachate and runoff from spent shale disposal sites and raw shale stockpiles,

- effluent TDS concentrations limited to $0.9 \mathrm{Mg} / \mathrm{d}$ $(1.0$ ton $/ d)$, and

- whenever practicable, treatment of process water before its disposal on spent shale piles.

Compliance with or deviation from these suggested practices should be clearly stated.

\subsubsection{Impacts on Biota}

Development of oil shale resources may have major effects on terrestrial and aquatic plant and animal communities and their associated habitats. Direct effects on biotic communities will be exacerbated by indirect effects related to the large population influx associated with the labor force. Effects on natural communities may be long term and may be cumulative with those from other energy developments (e.g., uranium, tar sands, and coal). The development and increased human presence associated with energy facilities could severely affect indigenous species (such as raptors) that are particularly sensitive to disturbance. Habitat destruction, increased legal and illegal hunting pressure, and increased mortality (e.g., road-kills and bird collisions with new power lines) may adversely affect wildlife populations.

Potential impacts on aquatic biota may result directly from project mining, construction, and operation or indirectly from the alteration of watershed hydrology. Increased erosion and sedimentation may degrade water quality in local streams. Water withdrawals may alter instream habitat, as well as lead to an increase in total dissolved solids concentrations in downstream portions of the Colorado River watershed (Bates and Thoem 1980). Toxic waste effluents may 
result in either acute or chronic stress on plankton, macrophyte, invertebrate, or fish populations.

Using baseline information on the affected environment, site survey data, and the project description, the environmental analysis should:

- describe the terrestrial and aquatic biota that may be affected, giving special attention to endangered, threatened, rare, or otherwise protected plant and animal species;

- characterize by dominant species and physical features all terrestrial and aquatic habitat types that will be disturbed;

- estimate the number of hectares of each type of habitat that will be disturbed during mining, construction, and operation;

- describe those features of reclamation plans for a11 disturbed areas that are designed to promote reestablishment of biotic communities, habitat features, and natural processes;

- evaluate the effects of the composite toxicity of individual waste effluents, and, where applicable, combined waste effluents on species of plants, invertebrates, fish, etc.; and

- include results of consultation with state and federal fish and wildlife agencies and conservation personnel.

\subsubsection{Solid Waste Disposal}

Successful disposal of the vast amounts of solid wastes produced by commercial oil shale projects is a major challenge. Because there is no previous experience with commercial-sized projects analogous to those proposed for western oil shale, careful planning will be required to prevent contamination of ground and surface waters and to achieve long-term stabilization and reclamation of spoil disposal areas. A western oil shale industry producing $1.6 \times 10^{5} \mathrm{~m}^{3}\left(1 \times 10^{6} \mathrm{bbl}\right)$ of shale oil per day might process $450 \times 10^{3} \mathrm{Mg}\left(500 \times 10^{6}\right.$ tons $)$ of 
shale per year and require the disposal of about $360 \times 10^{3} \mathrm{Mg}(400 \times$ $10^{6}$ tons) of solid waste (Moore and Mills 1977). Four types of solid wastes will be generated:

- fine particles of unprocessed shale generated during crushing operations,

- spent catalysts utilized in the numerous steps of upgrading or waste treatment process,

- $\quad$ spent shale that remains after retorting, and

- $\quad$ sludge from wastewater treatment process.

Catalysts are used in many stages of shale oil production, including hydrogenation steps in upgrading and the unit processes associated with the treatment of waste streams (e.g., Claus processes to remove sulfur). Guard beds of metalic elements used to trap hydrogen sulfide also have limited life spans and will produce solid wastes which must eventually be disposed. Because these spent catalysts include potentially toxic heavy metals (e.g., nickel, cobalt, copper, zinc, and molybdenum), special provisions must be made for their disposal (Bates and Thoem 1980). Regeneration and reuse of spent catalysts are preferable to their disposal in spent shale piles.

Most current oil shale development plans call for the disposal of spent shale in isolated gullies or canyons. The primary effects of the surface disposal of spent shale include changes in the landscape, disruption of existing land uses, loss or significant modification of natural ecosystems, and degradation of water and air quality by erosion and leaching. Secondary impacts such as creation of fugitive dust or leachates that affect not only the immediate area but also the surrounding region can also contribute significantly to water quality degradation.

The sludges produced from the treatment of liquid waste streams coming from the retort and upgrading processes will contain elevated concentrations of insoluble inorganic materials and trace elements. Because most of the toxic constituents in wastewaters (Table 4) will 
also be present in these sludges, but in more concentrated forms, their disposal should be given special attention and integrated with the overall project plan for solid wastes and hazardous materials.

Solid wastes generated at all stages in oil shale processing should be described. Disposal sites and methods for handling and treating wastes from all sources should be identified. The reclamation plan presented in Sect. 2.3.7 should be clearly linked to the discussion of solid waste disposal. Guidance from the Environmental Protection Agency for Best Management Practices for solid waste disposal (Bates and Thoem 1980) calls for the following:

- record keeping and reporting of all hazardous wastes produced,

- isolation and containment of all hazardous wastes,

- impermeable layers (e.g., clay lenses) below spent shale piles and other waste disposal areas to protect against groundwater contamination, and

- avoidance of the 100-year floodplain, wetlands, critical wildlife habitat areas, and recharge areas for sole-source aquifers in locating disposal areas.

The interpretation and applicability of the Resource Conservation and Recovery Act (Pub. L. 94-580) should be determined by consultation with appropriate state and federal agencies. A summary of the results of these consultations should be included.

\subsubsection{Reclamation}

Reclamation of mined land and spent shale disposal areas is a major undertaking for any oil shale operation. Plans for reclamation should be described in detail. The objectives of reclamation should be to (1) reduce water and wind erosion from the disturbed landscape, (2) restore the disturbed areas to productive use, and (3) ensure that long-term contamination of ground and surface waters by leachates from the reclaimed areas does not occur. 
Reclamation plans should include all areas disturbed during construction and operation of the proposed facility and describe:

- the location of all areas to be reclaimed (a map should be provided);

- handling and storage of topsoil;

- soil amendments to be used;

- irrigation plans and water sources;

- cover species to be used.

- measures to protect the reclaimed areas from grazing for sufficient time to allow establishment of new vegetation;

- a monitoring program to evaluate long-term success of reclamation; and

- schedule for implementation of specific portions of the plan.

\subsubsection{Socioeconomics}

Significant socioeconomic impacts may result from the development of an oil shale industry. Near-term development of oil shale is most likely to occur in the Piceance Basin of northwestern Colorado, which is rural and sparsely populated, as is true of the rest of the western oil shale region. Of the 12 towns that are likely to be affected by oil shale development in the Piceance Basin, only one has a population of over 5000 .

Boomtown effects on small communities resulting from a rapid and large population influx have been demonstrated in the western coal regions (Gilmore and Duff 1975). Housing and municipal services in small communities are often insufficient to handle large population increases (Cortese and Jones 1979). Tax revenues from the energy facilities lag several years behind the rise in local government expenditures required to meet increased demand for services and may not reach all, or even most, of those jurisdictions experiencing project-induced impacts. High-paying energy jobs draw labor away from 
lower-paying local employers and local inflation may occur, causing particular damage to low income residents and those on fixed incomes. Rapid population increases may be accompanied by cultural disruptions and a rise in crime rates. Population increase can also exacerbate effects from the energy development itself on air quality, water availability and quality, and surrounding natural habitats. Effects from development of oil shale resources may also be cumulative with those of other nearby energy developments such as oil shale, uranium, and coal exploitation.

Water supply (Sect. 2.3.3) may be especially critical because there is little water in many areas of the west, and oil shale operations often consume significant amounts of water. Although some of this water may be processed and reused, the water demands associated with the development of oil shale projects may have adverse effects on local communities and the quality of life in the impact region.

The analysis of socioeconomic impacts should include projections and/or analyses of the following information:

- rate and magnitude of population increase during construction and operation of the project and probable residential location of in-movers;

- capacity of existing and planned housing stock to accommodate project-induced housing demand in affected communities;

- the amount and timing of increased revenues and expenditures for the impacted jurisdictions as a result of project-related growth;

- adequacy of local transportation networks to handle increased worker and heavy equipment traffic;

- adequacy of local public services (e.g., water supplies and domestic waste treatment systems) to serve expected increased populations in affected communities.

- direct and secondary employment to be created by the proposed project and project-induced changes in the local economic character; 
impacts on structure and management of local government and major local organizations; and

- impacts to existing life-style, cultural, and ethnic characteristics of the impact region.

\subsubsection{Health and Safety}

Recent studies (U.S. DOE 1979, OTA 1980, Bates and Thoem 1980, Walsh et al. 1981) discuss the potential health and safety issues associated with oil shale projects. These publications form the basis for the following discussion of occupational and public health issues. The potential issues discussed below should be discussed by identifying those problems pertinent to the project under review and describing plans for avoiding or mitigating any effects on human health and safety. The following control methods should be considered in this review and discussion:

- $\quad$ worker training programs,

- design and maintenance of safe working environments, and

- health and monitoring programs.

\subsubsection{Occupational Health}

Blasting and drilling during mining will generate hazardous materials (e.g., silica), and related activities (e.g., the handling of raw and spent shale) will produce fugitive dust (Sect.22.3.2). Silica dust has long been recognized as a major health hazard of underground mining related to the development of silicosis, chronic bronchitis, and other pulmonary disorders. The potential for this dust hazard is difficult to assess for oil shale operations because very limited data are available. However, Costello (1980) and Rudnick et al. (1980) report no evidence of increased respiratory disease in miners working at the Anvil Point Shale 0il Facility near Rifle, Colorado. If commercial-scale production were to require a miner to spend an entire 8-h shift working under the present conditions at Anvil Point, the worker would receive an excessive exposure to dust (Rudnick et al. 
1980). Personnel spending a full shift in crushing, retorting, and shale disposal operations would also receive excessive exposures. Gas and vapor levels for all stages of mining, however, do not exceed present exposure standards (Holland and Stafford 1981). Rudnick et al. (1980) suggest that maintenance personnel, often working in areas of high dust and low ventilation, should wear respiratory equipment.

Particulates, including fugitive dust emissions during surface or underground mining should be readily controlled by existing technology, such as wetting, baghouse filters, and various wet scrubbing schemes (Peterson et al. 1980). Mining equipment should incorporate water sprays for dust control. These water sprays need constant maintenance to ensure proper performance.

The degree of ventilation required within commercial-scale MIS mines has not been established. Peterson et al. (1980) note that retorting in one area will occur simultaneously with mining and processing in other areas, and the probability of leaks of fugitive emissions from an active retort into an adjacent area is unknown. Such leaks could expose workers to health hazards ranging from carbon monoxide poisoning to long-term toxic conditions. Careful planning and management, as well as proper ventilation procedures, are necessary to prevent these problems. Unused areas in the mines can be closed off with hanging cloths ("brattice" cloths) to improve ventilation in the areas of the mine that are in use.

A second health concern associated with mining is the possible release of polynuclear aromatic hydrocarbons (PAHs) and trace elements. Published data on the toxicity and carcinogenicity of oil shale materials used in animal studies are extensive. However, recent studies (Rudnick et al. 1980, Costello 1980) on workers employed at the Anvil Point 0il Shale Facility indicate no apparent incidence of chronic or acute disease directly attributable to exposure to oil shale or its retorting products. Both studies do show a greater correlation between pulmonary disorders or cancer and exposure to radioactivity or smoking rather than to exposure to oil shale. Costello (1980) points out, however, that the actual exposures to shale oil were brief, and it 
is too early to draw conclusions regarding carcinogenic risk because some forms of cancer have a long latent period for development. As with silica and fugitive dust, there are very limited data available, and the potential health risk for the oil shale industry is unknown.

A third potential health risk for oil shale miners is exposure to excessive noise levels. This is of particular concern in underground operations when the primary noise sources are booster fans, drills, blasting, conveyers, and mining machines. Most underground miners are chronically exposed to sound levels greater than the established standards. Such exposure can cause hearing loss, and some data suggest that deleterious effects to the cardiovascular and nervous systems may occur. Miners also experience short-term acute exposure from blasting. Rotation of workers may alleviate exposure to excessive noise levels. Each worker should be fitted with ear plugs. Periodic monitoring of worker's hearing acuity may signal any hearing loss and facilitate rotation to other areas.

Retorting oil shale at high temperatures will form some PAH-containing carcinogens. Some PAHs are undoubtedly released during the crushing and grinding processes due to the mechanical and thermal degradation of kerogen. Workers should be protected from inhalation of raw shale aerosol or dust and from repeated skin exposure to raw shale oil (Peterson et al. 1980). The carcinogenicity of these compounds is a major potential health hazard for retort workers, and the problems involved are basically similar to those of conventional oil refineries (Bates and Thoem 1980). In their report, Holland and Stafford (1981) discuss the presence of arsenic in oil shale, product streams from 011 shale retorts, process waters, and crude oil products. Arsenic may be found in all fractions of crude shale oil at concentrations up to 1000 times that of natural crude levels (Bates and Thoem 1980). Because inorganic arsenicals, including nickel arsenides, have been shown to be carcinogenic, teratogenic, and embryotoxic, the release of these substances to the environment, or possible worker exposures to them, during oil shale recovery processes must be carefully monitored and controlled (Holland and Stafford 1981). Upgrading of product streams 
reduces carcinogenicity as well as toxic effects of chemicals in the crude shale oil. Therefore, any significant increase in health problems will occur during processing when the shale oils differ considerably from natural crude oils in physical and chemical properties (Bates and Thoem 1980).

In shale oil retorting and upgrading facilities and in conventional refineries, liquids and gases must be transported in air-tight pipes which are carefully maintained and observed to detect and repair leaks. Maintenance workers assigned to such tasks are those most likely to be exposed to PAHs and show higher than average mortality rates due to malignant neoplasms (Costello 1980). Engineering controls and improvements in materials of construction may reduce these risks. However, a program for proper fit and maintenance or personnel protective equipment should be implemented (Holland and Stafford 1981). Arsenic, nickel, chlorine, sulfur, nitrogen, and heavy metals are additional hazardous substances found in the crude oil.

\subsubsection{Occupational Safety}

The safety hazards associated with underground or open-pit mining of oil shale are in general similar to those of hard rock mining and would include accidents from rock falls, explosions and fires, electrocution, heavy mining equipment, and vehicular traffic. There are no data available on accidental deaths and injuries associated with oil shale mining, although the occupational health hazards are expected to be lower than those for mining an equivalent quantity of coal (U.S. EPA 1977). Because shale is relatively hard compared to coal, the probability of mine cave-in or collapse, which accounts for 40 to $50 \%$ of coal mine fatalities (Commonwealth of Kentucky 1979 and 1980, U.S. EPA 1977), is less. Hazards unique to oil shale operations would occur primarily in MIS processes. The high temperatures and fires associated with these processes may expose miners to risks not experienced by other underground miners.

The safety hazards arising from retorting and upgrading include explosions, fire and heat, electrocution, and exposure to hot liquids. 
The degree of risk, however, is probably less than that for the mining phase. Safety risks associated with retorting and upgrading would be no higher than those associated with mineral processing and conventional petroleum refining.

\subsubsection{Public Health and Safety}

Operation of a large oil shale plant would result in large volumes of solid waste and air emissions as well as potential leachates from spent shale. Compliance with federal and state ambient air quality standards may constrain development of the oil shale industry because major potential releases of criteria pollutants, organics, and trace elements are likely to occur. Water used in oil shale processes will become contaminated with toxic chemicals, minerals, and trace elements, while water removed from shale beds will contain chlorine, carbonates, sulfates, mercury, selenium, arsenic, and various organic compounds such as phenols and carboxylic acids (U.S. EPA 1977). Peterson et al. (1980) suggest that mercury might be a particular problem as its fate during the retorting process is unknown and mercury contamination and toxicity pose serious risks. This potential problem needs a careful assessment. Industry goals include zero release into surface streams and groundwater supplies via incorporation of cleanup and recycling processes. To date, no satisfactory methods have been identified for treating wastewater problems encountered during in situ processes (U.S. EPA 1977). In situ processes present a significant challenge in finding ways to make environmental measurements that would ensure containment of emissions and effluents.

The greatest environmental health problem in oil shale development may be associated with the disposal of spent shale (Sect. 2.3.5) because approximately $1.4 \times 10^{-3} \mathrm{~kg}$ of waste remain for every barrel of 011 produced (U.S. EPA 1977). Health concerns are related to the potentially harmful amounts of mineral salts contained in spent shale, as well as to toxic trace elements that could be leached into surface water and groundwater. However, according to Resources Recovery and 
Conservation Act criteria, leachate biotest studies by the Anvil Point oil Shale Research Facility indicate that leaching from spent shale may not be a significant health problem (Heistand 1980). 


\subsection{REFERENCES}

Bates, E. R., and T. L. Thoem (eds.). 1980. Environmental perspective on the emerging oil shale industry. EPA-600/2-80-205a. Industrial Environmental Research Laboratory, U.S. Environmental Protection Agency, Cincinnati, Ohio. $324 \mathrm{pp}$.

Commonwealth of Kentucky. 1979. Bulletin (Dec. 1979). Department of Mines and Minerals, Lexington, Kentucky.

. 1980. Bulletin (Oct.-Dec. 1980). Department of Mines and Minerals, Lexington, Kentucky.

Costello, J. 1980. Retrospective mortality study of oil shale workers, 1948-1977. pp. 369-375. IN J. H. Gary (ed.), Proc., Thirteenth 0il Shale Symposium. Colorado School of Mines Press, Golden, Colorado.

Cortese, Charles F., and B. Jones. 1979. Energy boomtown: A social impact model and annotated bibliography. IN Charles T. Unseld et al. (eds.), Study of Nuclear and Alternative Energy Systems, Supporting Paper 5: Sociopolitical Effects of Energy Use and Policy. National Academy of Sciences, Washington, D.C.

Gilmore, J. S., and M. K. Duff. 1975. Boomtown growth management: A case study of Rock Springs-Green River, Wyoming. Westview Press, Boulder, Colorado.

Heistand, R. N. 1980. Retorted oil shale disposal research. Am. Chem. Soc. Symp. $25(3): 125-136$.

Holland, L. M., and C. G. Stafford. 1981. The Los Alamos integrated oil shale health and environmental program: A status report. LA-8665-SR. Los Alamos Scientific Laboratory, Los Alamos, New Mexico.

Kinney, W. L., A. N. Brecheisen, and V. W. Lambou. 1979. Surface water quality parameters for monitoring oil shale development. EPA-600/4-79-018. U.S. Environmental Protection Agency, Las Vegas, Nevada. $141 \mathrm{pp}$.

Moore, R., and T. Mills. 1977. An environmental guide to western surface mining. Part II: Impacts, mitigation, and monitoring. FWS/0BS-78/04. U.S. Fish and Wildlife Service, Western Energy Land Use Team, Fort Collins, Colorado. $384 \mathrm{pp.}$

National Academy of Sciences (NAS). 1980. Mining and processing of shale $0 i 1$ and tar sands. Appendix II. IN Surface Mining of Non-Coal Minerals. Washington, D.C. 
Office of Technology Assessment (OTA). 1980. An assessment of oil shale technologies. OTA-M-118. Congress of the United States, Washington, D.C.

Peterson, E. J., E. F. Thode, P. Wagner, and P. L. Wanek. 1980. An integrated environmental control technology approach to oil shale commercialization. LA-8378. Los Alamos Scientific Laboratory, Los Alamos, New Mexico.

Rudnick, J., L. L. Garcia, G. L. Voclz, and H. F. Schulte. 1980. Paraho oil shale workers occupational health study. LA-8459-MS. Los Alamos Scientific Laboratory, Los Alamos, New Mexico.

Schramm, L.W. 1980. U.S. shale oil forecasts (1985-1995). DOE/EIA$0813 / 20$. Energy Information Administration, U.S. Department of Energy, Washington, D.C. $25 \mathrm{pp}$.

Slawson, G. C., Jr. (ed.). 1979. Groundwater quality monitoring of western $0 i 1$ shale development: Identification and priority ranking of potential pollution sources. EPA-600/7-79-023. U.S. Environmental Protection Agency, Las Vegas, Nevada. 214 pp.

U.S. Department of Energy (U.S. DOE). 1979. Environmental Development Plan: 0il Shale. DOE/EDP-0051. Washington, D.C.

U.S. Department of Interior (U.S. DOI). 1973. Final Environmental Statement for the Prototype $0 i 1$ Shale Leasing Program, Vol. 1, Regional Impacts of 0 il Shale Development. EIS-AA-73-1423-F-1. Washington, D.C.

U.S. Environmental Protection Agency (U.S. EPA). 1977. $0 i 1$ shale and the environment. EPA-600/4-77-033. Washington, D.C.

Walsh, P. J., E. L. Etnier, and A. P. Watson. 1981. Occupational and public health and safety implications of unconventional energy technologies. III. Fossil fuels. Environ. Manage. 5(6):483-494. 


\section{TAR SAND}

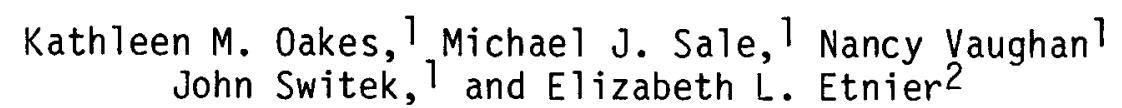

\subsection{RESOURCE DESCRIPTION}

Tar sand is any consolidated or unconsolidated rock (excluding coal, oil shale, or gilsonite) that contains hydrocarbon-bearing material with gas-free viscosity (greater than 100 Pascal seconds) at reservoir temperatures. Host rocks are usually sands, sandstones, or limestones of Mississippian age or younger, but any rock of any age may contain bitumen if the necessary porosity is present (Ball and Associates 1975).

The western hemisphere apparently has the majority of the world's tar sand resource, with the largest deposits occurring in Canada and Columbia (Table 5). In the United States, oil-impregnated rocks are known to occur in 22 states, with a total estimated resource of 4.8 to $5.2 \times 10^{6} \mathrm{~m}^{3}\left(30-33 \times 10^{9} \mathrm{bbl}\right)$ (deNevers et al. 1979, U.S. DOE 1979). Only six states (California, Utah, New Mexico, Texas, Alabama, and Kentucky) contain deposits which could be commercially exploited (Table 6). Utah has by far the largest known deposits, with more than $4.0 \times 10^{9} \mathrm{~m}^{3}\left(29 \times 10^{9} \mathrm{bbl}\right)$ in place.

Commercial development of tar sand deposits as a source of fossil fue 1 is most advanced in Canada, where the Athabasca deposits in northern Alberta are being mined. In 1978, these deposits were yielding more than $23,800 \mathrm{~m}^{3}(150,000 \mathrm{bbl})$ of crude $0 i 1$ per day, with an additional capacity of $47,700 \mathrm{~m}^{3}(300,000 \mathrm{bbl})$ per day under development.

In the United States, tar sand deposits have been used only as a source of paving asphalt. A recent estimate of the nation's recoverable

\footnotetext{
IEnvironmental Sciences Division, ORNL. ${ }^{2}$ Health and Safety Research Division, ORNL.
} 
Table 5. World tar sand resources (McRae et al. 1977) a $^{a}$

\begin{tabular}{|c|c|c|}
\hline Area & $\begin{array}{l}\text { Estimated } \\
\text { resource } \\
\left(\mathrm{m}^{3}\right)\end{array}$ & $\begin{array}{l}\text { Percent of } \\
\text { world resources }\end{array}$ \\
\hline \multicolumn{3}{|l|}{ North America } \\
\hline Canada & $1.4 \times 10^{11}$ & 41 \\
\hline Trinidad and Tobago & $1.1 \times 10^{10}$ & 3 \\
\hline United States & $4.3 \times 10^{9}$ & 1 \\
\hline \multicolumn{3}{|l|}{ South America } \\
\hline Columbia & $1.8 \times 10^{11}$ & 52 \\
\hline Venezuela & $1.2 \times 10^{10}$ & 3 \\
\hline \multicolumn{3}{|l|}{ Africa } \\
\hline Malagasy Republic & $2.7 \times 10^{8}$ & 0.1 \\
\hline \multicolumn{3}{|l|}{ Europe } \\
\hline Albania & $6.4 \times 10_{6}^{7}$ & 0.1 \\
\hline $\begin{array}{l}\text { Rumania } \\
\text { USSR }\end{array}$ & $4.8 \times 10^{6}$ & 0.1 \\
\hline USSR & $4.8 \times 10^{6}$ & 0.1 \\
\hline
\end{tabular}

Table 6. Estimated commerical tar sand deposits in the United States (McRae et al. 1977)

\begin{tabular}{llc}
\hline \multicolumn{1}{c}{ State } & $\begin{array}{c}\text { Est imated } \\
\text { resource } \\
\left(\mathrm{m}^{3}\right)\end{array}$ & $\begin{array}{c}\text { Percent of } \\
\text { U.S. resources }\end{array}$ \\
\hline Alabama & $1.9 \times 10^{8}$ & 4.3 \\
California & $4.7 \times 10^{7}$ & 1.1 \\
Kentucky & $5.4 \times 10^{7}$ & 0.6 \\
New Mexico & $9.1 \times 10^{6}$ & 0.2 \\
Texas & $2.1 \times 10^{9}$ & 0.5 \\
Utah & $4.0 \times 10^{9}$ & 93.3 \\
Total commercial deposits & $4.3 \times 10^{9}$ & \\
\hline
\end{tabular}


reserves using proven technology (McRae et al. 1977) is only 0.3 to 0.9 $\times 10^{9} \mathrm{~m}^{3}$ (2.0 to $2.5 \times 10^{9}$ bbl). Not only are the reserves more limited than in Canada, but the bitumen is also more tightly bound to the sand and therefore more difficult to separate. Proposed in situ extraction techniques may allow more of the resource to be exploited, but the cost in energy and water is considerable (Kuuskraa et al. 1978).

Processes for extracting and separating bitumen from tar sand deposits fall into two general categories: those that extract the ore using surface mining techniques and those that use in situ extraction. The Canadian experience has been primarily with surface mining, whereas plans for developing the U.S. resource include in situ techniques as we11. Deposits in the Athabasca region are generally highly saturated and continuous $[15 \mathrm{~m}(50 \mathrm{ft})$ thick] and have few barren layers. In contrast, however, the U.S. deposits (especially in Utah) are about $6 \mathrm{~m}$ $(20 \mathrm{ft})$ thick and have thick barren intervening layers. In addition, the bitumen in the U.S. tar sand is more tightly bound to the sand grains due to the absence or greatly reduced thickness of the water layer.

In general, the economics of underground mining are less favorable for tar sand recovery than in situ recovery. Although underground mining may be feasible for some consolidated deposits in Utah, unconsolidated deposits do not possess sufficient strength to permit underground mining.

\subsection{TECHNOLOGY OVERVIEW}

\subsubsection{Surface Mining}

Surface mining has proven to be technically feasible for some of the Athabasca tar sand deposits. Economic constraints on surface mining include depth of overburden, overburden to net pay ratios, bitumen content (weight percent), and size of the deposit. In Canada, deposits having overburden thicknesses of less than $46 \mathrm{~m}$ and overburden to net pay ratios of less than one are considered potentially minable. 
The optimum size of a deposit in Canada is considered to be $80 \times 10^{6}$ to $160 \times 10^{6} \mathrm{~m}^{3}\left(0.5-1.0 \times 10^{9} \mathrm{bbl}\right)$ of minable ore.

Because U.S. deposits are relatively thin and overburden to net pay ratios are too high, surface mining may be greatly limited. Additional important considerations are the need for drilling and blasting and the steepness of the terrain. In the steep canyon terrain in which some Utah deposits occur, the long-wall stripping method currently used in coal mining may be adapted (U.S. EPA 1976).

\subsubsection{Separation Processes}

Where tar sand deposits are surface mined, bitumen must be separated from the sand after extraction (Fig. 3). In large operations, such as those of Great Canadian $0 i 1$ Sand, Inc. (GCOS), and Syncrude, tar sand ore is first fed into large conditioning drums (tumblers), and then steam, hot water, and a small amount of sodium hydroxide are added to separate the bitumen from most of the coarse sand (Fig. 3). The processed coarse sand is returned to the mine for back filling (U.S. DOE 1979). The tar is discharged to a vibrating screen where large lumps of tar sand are removed for return to the conditioning drums. The oil slurry is pumped to separation cells where a froth is formed.

This oil froth, along with some sand and water, is skimmed off the surface, diluted with naphtha, and run through centrifuges for final separation (Fig. 3). Sand from the separation cells and centrifuges is sent to a tailings pond. A middlings stream is withdrawn from the layer beneath the froth in the separation cells. A portion of this stream is returned to the conditioning drum for additional treatment, and the remainder is sent to scavenger cells and froth settlers. Froth from the settlers goes to the centrifuges (U.S. DOE 1979).

An alternative approach being considered by Getty $0 i 1$ Co. is a solvent extraction technique developed by the Dravo Corporation at Pittsburgh. A volatile hydrocarbon solvent would initially be used to wash the sand from the 0il, followed by a multistep distillation process that would separate oil, water, and solvent. 


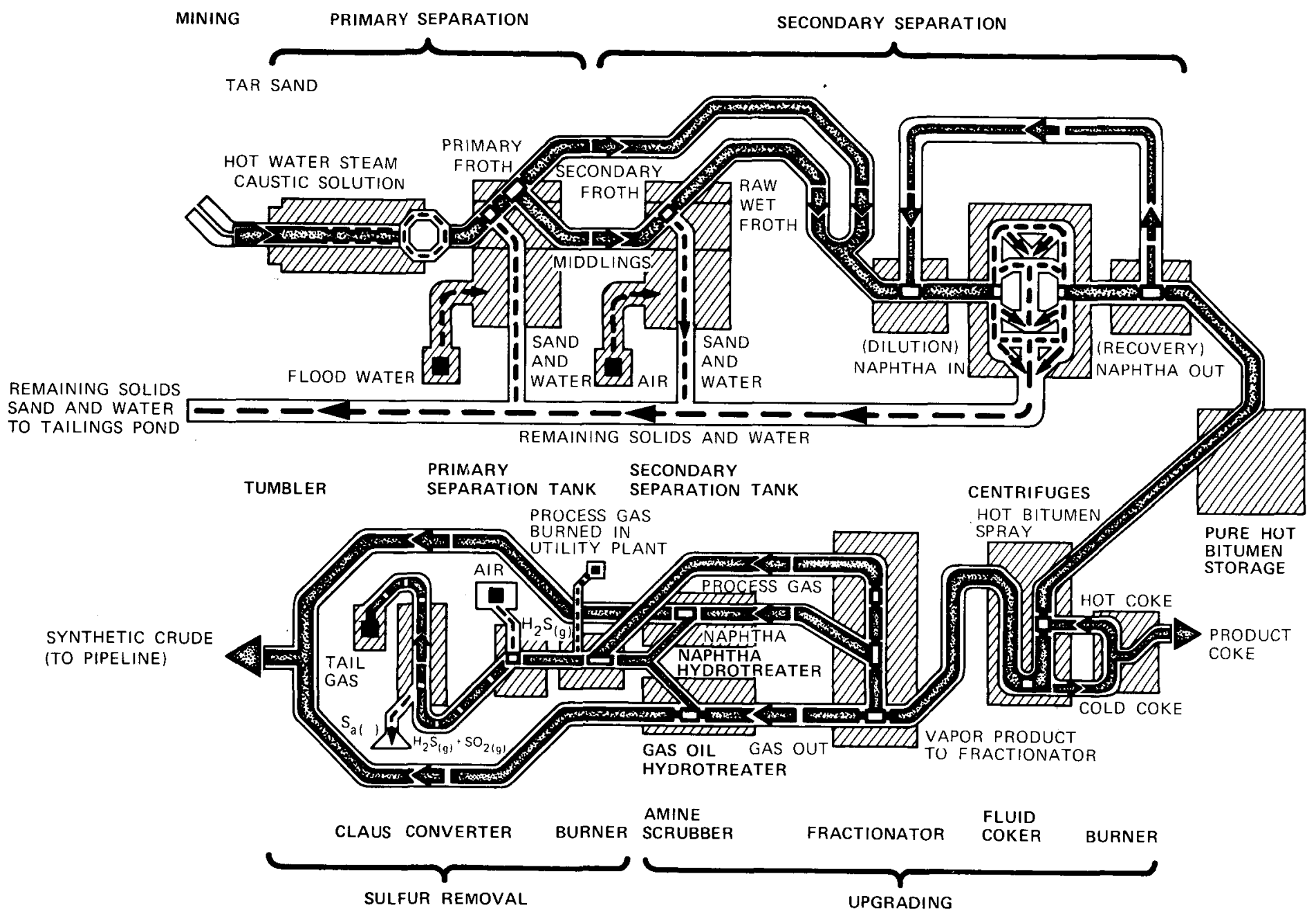

Fig. 3. Synthetic crude oil process flow from surface-mined Athabaska tar sand. [SOURCE: Maugh 1978. (Copyright 1978 by the American Association for the Advancement of Science). Redrawn with permission from T. H. Maugh, II, and AAAS.] 


\subsubsection{Upgrading Processes}

The raw tar sand oil must be upgraded to remove mineral fines, sulfur, and trace metals and to decrease the density, viscosity, and carbon-hydrogen ratio of the product. This upgrading is accomplished in both the GCOS and Syncrude operations by coking (i.e., heating the bitumen to a temperature where it decomposes) (Fig. 3 ). When the process is complete, a gaseous product, a liquid product, and a solid coke result (Baughman 1978).

The liquid from the coker goes through three hydrotreaters (Fig. 3) that distill naphtha, kerosene, and gas oil. The three liquids are then blended to make synthetic crude oil for marketing (deNevers et al. 1979). Gaseous waste products of hydrotreating are combined with gas from the coker and sent to an amine scrubber to remove hydrogen sulfide. This gas is then treated in a $\mathrm{Cl}$ laus converter to yield elemental sulfur. The cleaned fuel gas is used for plant heating or is fed to the hydrogen plant which supplies the hydrotreaters (U.S. EPA 1976). The solid coke produced by GCOS is used as fuel for heat and electricity generation at its facilities. Syncrude disposes of its coke as a waste product.

Other approaches to upgrading include Shell Canada's plans to replace coking with a combination of vacuum flashing and solvent deasphaltation (Land et al. 1975) and an anhydrous solvent extraction process. In this latter process, fresh tar sand is mixed with solvent and water. The mixture is run through a three-stage countercurrent wash. At the end of each stage the sand is allowed to settle, and the fluids are drained through the sand until no fluid is left. This step removes the bitumen from the sand in much the same way as the rinse cycle in a washing machine removes the dirt and soap from the laundry. The solvent-bitumen and solvent-solids systems are then separated, with the solvent being recycled, the bitumen being sent for further upgrading, and the sand being removed for disposal.

Currently active or proposed tar sands projects will produce an upgraded crude oil on the site, and offsite refineries will be used for further distillation. 


\subsubsection{In Situ Extraction}

Deposits that lack the competence to be mined by underground mining methods and are too deep (greater than $46 \mathrm{~m}$ ) to use surface mining techniques will probably be exploited by some form of in situ processing. In situ methods involve lowering the viscosity of the bitumen in the ore zone so that the product can be pumped to the surface. Proposed in situ methods include chemical solvent injection, steam-hot water injection, and combustion.

The chemical injection method injects a chemical solvent of either hydrocarbon-based solvents or aqueous alkaline surfactants into the tar sand deposit to dissolve the bitumen. Such injections have been successfully used in California's heavy-oil fields using naphthenes and aromatic solvents (U.S. Bureau of Mines 1972), but the viscosities of these heavy oils are considerably less than those of bitumen. On the other hand, Shell Canada has experimented with both miscible solvents and a combination of aqueous-based emulsifying fluids and sodium hydroxide, but neither approach has proven to be economically feasible (Doscher 1967). Injection of solvents is sometimes preceded by hydraulic or explosive fracturing (U.S. Bureau of Mines 1972). While chemical injection techniques work well in oil fields, more study is needed to demonstrate their effectiveness in tar sand deposits.

Steam injection methods include cyclic injection and steam flooding. Cyclic steaming has been successfully used to increase production in heavy oil fields. The process involves drilling a closely-spaced pattern of wells into the deposit and injecting up to $4000 \mathrm{~m}^{3}(25,000 \mathrm{bbl})$ of $260^{\circ}$ to $370^{\circ} \mathrm{C}$ steam into each well. Once the steam has been injected, the wells are shut off and allowed to soak, then opened again for production (U.S. EPA 1976). Imperial 0i1, Ltd., installed a $795-\mathrm{m}^{3}(5000 \mathrm{bbl})$ per day pilot project in the Cold Lake oil sands in Alberta (Anonymous 1975). The process consumed $3 \mathrm{~m}^{3}$ of water for each cubic meter of oil produced, with recovery of only 20 to $30 \%$ of the oil in place. At the time of the pilot project, a question arose about the economic and energy balance feasibility; specifically, was the $3: 1$ water:oil ratio with only 20 to $30 \%$ oil recovery an 
economic process? More research on the suitability of cyclic steaming is underway.

With the steam flooding technique, injected steam reduces the viscosity of the bitumen and drives it toward a nearby production well. A surfactant emulsifier is generally injected with the steam to enhance viscosity reduction. In a pilot project conducted by shell Canada, $4 \mathrm{~m}^{3}$ of steam and caustic were injected for each cubic meter of 0 il produced (Baughman 1978). An estimated 50 to $70 \%$ recovery of oil could be realized, but the commercial feasibility would depend on reducing the required energy and water impacts.

The U.S. Department of Energy Laramie Energy Technology Center conducted a steam flooding experiment at the Vernal, Utah, site (Lindberg 1980). An average production rate of $1.1 \mathrm{~m}^{3} / \mathrm{d}$ (oil) and $6.3 \mathrm{~m}^{3} / \mathrm{d}$ (water) was achieved. These results were encouraging enough to continue further evaluations of the technical feasibility of steam flooding tar sand deposits (Johnson et al. 1981).

Combustion of bitumen in place provides heat to lower the viscosity of surrounding hydrocarbons. Oxygen for combustion and for driving the produced hydrocarbons to a production well is provided by the injection of high pressure air from the surface (Doscher 1967). Fracturing may be required to ensure good interconnection between injection and production wells.

A forward combustion or a reverse combustion strategy may be used. In the former case, ignition is started in the injection well, and the combustion front moves through the formation toward the production we11. The injected air is heated to $315^{\circ}$ to $480^{\circ} \mathrm{C}$ in the burn zone and mobilizes the lighter constituents of bitumen in front of the combustion front, driving them toward the production well. The mobilized hydrocarbons, however, tend to condense on entering the cold zone between the burn front and the production well, plugging the pores and restricting flow to the production wells (Doscher 1967).

In reverse combustion, ignition occurs at the production well while air is pumped into the injection well. The burn front migrates toward the injection well, counter to the direction of air flow. The 
mobilized bitumen is conducted through the hot burned-out zone to the production well to prevent condensation. The $0 i 1$ produced is of higher quality than that produced by forward combustion because the bitumen has been thermally cracked (Cupps et a1. 1975). Field and laboratory experiments of reverse combustion carried out by the Laramie Energy Technology Center (Land et a1. 1975, 1977) showed that the temperatures achieved were much lower than expected. The resulting product was much more viscous than anticipated and congealed in the surface pipelines. Laboratory tests indicated $50 \%$ recovery of bitumen in place was possible with $40 \%$ remaining in the deposit and $10 \%$ consumed in combustion (Land et al. 1975). A second test was performed using a reverse combustion phase followed by a forward combustion phase (echoing). Approximately $25 \%\left(92.2 \mathrm{~m}^{3}\right.$ or $\left.580 \mathrm{bbl}\right)$ of the in-place bitumen was produced, and $49 \%$ air return was achieved. The volume of the $0 i 1$ produced and percent air return make the scheme look very promising.

A combination forward combustion-water flood process has been developed by Amoco Production Company to produce bitumen from the Gregoire Lake area in northern Alberta. The process starts as a forward combustion burn until the reservoir reaches $815^{\circ} \mathrm{C}$. Water is then injected with the air, lowering the combustion temperature and generating steam that transmits heat into the formation and rapidly accelerates the recovery process (Doscher 1967). Air requirements are much less than those for standard forward combustion. Field results from a small plot yielded $32 \%$ of the bitumen in place. This method is considered superior to ordinary combustion techniques because a higher quality oil is recovered.

\subsection{POTENTIALLY SIGNIFICANT ISSUES}

Potentially significant environmental impacts associated with construction, mining, operation, and reclamation of proposed tar sand projects should be assessed as appropriate to the project under review. The following issues are those most likely to be significant 
for tar sand projects and should be carefully reviewed. If this review shows that the issue is not relevant to the proposed project, then the the reasons for not presenting a detailed analysis should be briefly discussed.

\subsubsection{Land Use}

Over 90\% of the nation's tar sand deposits are in Utah (Table 6). Development of the southeastern Utah deposits has the greatest potential for conflict with national parks, monuments, and recreation areas; in fact, some of the deposits are within the boundaries of such protected areas. In both southeast and northeast Utah, conflicts with established and proposed U.S. Forest Service and U.S. Bureau of Land Management wilderness areas may occur. Extensive Indian lands in the Uinta Basin may also coincide with tar sand deposits.

A commerical-size surface mining operation will disturb several hundred to a few thousand hectares of land and commit several hundred more to settling ponds for spent ore sands (Norman and Norman 1978). In situ recovery methods will also involve considerable land disturbance because wells are closely spaced. Mining disturbance, combined with construction of plant facilities for separation and upgrading of bitumen, will represent an intrusion into the present natural setting of the region. Increased traffic and numbers of people could also adversely affect surrounding lands.

Although tar sand developments in California, Texas, New Mexico, and Alabama may have a lower probability of extensive land-use conflicts than similar developments in Utah, some adverse effects on land use are nevertheless likely and should be carefully reviewed.

For the project site and surrounding area, the following should be described:

- present and planned land use;

- present and projected 1 and ownership; 
- national parks, national monuments, recreation areas, existing or proposed wilderness areas, and scenic, historic, or archaeologic sites or landmarks;

- the visibility of the proposed site and associated facilities from public use areas (e.g., trails, canyon overlooks, and picnic/camping areas); and

- Indian-owned lands and areas sacred to local Indian tribes.

A map should be included to show surrounding land uses and potential routes for heavy equipment and construction traffic associated with the-project. The possibility of adverse effects from increased traffic on roads through sensitive land-use areas (e.g., Indian 1 ands or wilderness areas) should be addressed.

\subsubsection{Air Quality}

Some tar sand resources are within or adjacent to Class I air quality regions, such as national parks (Sect. 3.3.1), where release of criteria atmospheric pollutants will be severely restricted by prevention of significant deterioration (PSD) provisions. Furthermore, in Utah, effects on air quality from nearby oil shale, uranium, and coal developments will be cumulative with those from tar sand, and PSD increments may not be available.

Surface mining of tar sand deposits has the potential to release large quantitites of particulates as dust. Mining will also expose large areas of fresh bitumen ore, possibly releasing volatile hydrocarbons to the atmosphere (U.S. EPA 1976). Hydrocarbons will also be emitted during bitumen separation (especially by the solvent extraction process) and during upgrading, storage, and transfer of the produced oil. Potentially large emissions of sulfur oxides $\left(\mathrm{SO}_{x}\right)$ could come from combustion of coke or product fuel to provide process heat for bitumen separation and from the tail-gas stream of the Claus plant associated with the upgrading of the separated bitumen. The potential for $\mathrm{SO}_{\mathrm{x}}$ releases will be greatest in southeast Utah where the bitumen is about $5 \%$ sulfur, as compared to only $0.5 \%$ sulfur in the 
Uinta Basin deposits (deNevers et al. 1979). Combustion of product fuel and in situ processes that use combustion will also release quantities of nitrogen oxides, particulates, and hydrocarbons.

In addition to general background information, specific information should be developed on the following:

- all affected Air Quality Control Regions (ACQRs), with special emphasis on Class I areas;

- local meteorology (local airport data and onsite measurements);

- local air quality (U.S. EPA and/or state monitoring data, monitoring data from nearby facilities, às available, and onsite baseline monitoring data, if required);

- proposed use of air pollution control devices, including a realistic estimate of efficiency and downtime;

- availability of other mitigation measures (e.g., siting facilities to maximize dispersion of atmospheric emissions); and

- any proposed air quality monitoring program.

\subsubsection{Water Use}

The availability of sufficient quantities of water for $t a r$ sand projects is a potential major environmental issue. Extraction techniques involving steam injection were estimated to consume from 3 to $6 \mathrm{~m}^{3}$ of water per cubic meter of $0 i 1$ produced based on experience in Canada (deNevers et al. 1979). Other water uses range from dust control to domestic water requirements for the increased population associated with the project work force. Because high quality tar sand deposits are found predominantly in regions of the United States in which freshwater resources are a limited commodity, project environmental analyses must evaluate water resource availability and the implications of project water use to other regional water users. 
The following should be included:

- sources of water available for project development;

- best estimates of quantities required under various consumptive and nonconsumptive water-use categories;

- for projects using groundwater resources (e.g., aquifer yield, quality, and recharge capacity), evaluation of the effects on and interrelationships with surrounding groundwater uses;

- for projects using surface water resources, documentation of the availability of adequate water rights or entitlements;

- quantification of available yields from surface water sources, and potential adverse impacts to downstream water users; and

- dependency of project operation on the construction of related water projects.

A11 opportunities for water recycling and conservation within the project design should be evaluated, and those adapted for the project should be emphasized. Zero-effluent operations are desirable, whenever achievable, to minimize effects on ambient water quality.

\subsubsection{Water Quality}

Potential mechanisms for groundwater and surface water pollution that are involved in the development of tar sand deposits include:

- increased erosion and sediment loading from mining and construction activities;

- leaching or overflow from tailings retention basins;

- runoff from exposed ore deposits, stockpiled materials, and solid waste disposal sites;

- contamination of groundwater aquifers by injection fluids, high temperature, salinity, or soluble organics and metals; 
- point-source discharges of waste effluents from surface extraction and upgrading processes; and

- accidental spills of process and waste streams and finished syncrude or petroleum products.

Each of these mechanisms should be discussed where appropriate. Pollution control strategies and monitoring plans should be presented to ensure that water quality degradation does not occur from these sources. Effects on groundwater quality are most likely to occur with projects using in situ extraction techniques or aquifer reinjection as a method for aqueous waste disposal. Surface water quality effects will be related to disturbance of land surfaces associated with mining, construction, and disposal of solid wastes. Point source effluents will originate from water coproduced during bitumen extraction and from process waste streams associated with sulfur removal, backwash, upgrading condensates, and cooling tower and boiler feed blowdown.

Specific pollutants from tar sand processing are similar to those from coal or uranium mining, enhanced oil recovery, petroleum refining, and the coal conversion/synfuels industry. Some of the potential waste constituents that require attention are listed in Table 7.

Table 7. Potential waste constituents from tar sand processing

Biochemical oxygen demand (BOD) Total suspended solids (TSS) Acidity or alkalinity

Ammonia

Sulfur compounds

Heat

Chemical oxygen demand (COD)

$0 i 1$ and grease
Total dissolved solids (TDS)

Cyanide

Chlorides

Phenolics

Polynuclear aromatic hydrocarbons (PAHs)

Trace metals (As, Cd, $\mathrm{Cr}, \mathrm{Cu}$, $\mathrm{Pb}, \mathrm{Hg}, \mathrm{Ni}, \mathrm{Ag}, \mathrm{Zn}, \mathrm{Mn}$ ) 
To address water quality issues, the environmental analysis should contain information on the predicted composition of effluents, comparisons to ambient water quality conditions, and applicable water quality standards. Chemical composition and leachability of specific tar sand ores should also be included. Composition and quantities of process effluents should be identified in sufficient detail to account for approximate material balances through a process flow diagram. Required surface discharge or aquifer reinjection permits should be listed along with applicable water quality limitations.

\subsubsection{Impacts on Biota}

Large-scale tar sand development are likely to destroy many hectares of natural vegetation and terrestrial and aquatic habitat as a result of both the energy facilities themselves and the large population influx associated with the labor force. Effects on natural communities will be cumulative with those from other energy developments such as uranium, oil shale, and coal in Utah. The development and increased human presence associated with energy facilities could severely affect species, such as raptors, that are sensitive to disturbance. Habitat destruction, increased legal and illegal hunting pressure, and increased mortality (e.g., from road-kills and bird collisions with new power lines) could adversely affect wildlife populations.

Potential impacts on aquatic biota may result from either point or nonpoint effluents originating from project mining, construction, and operation. Increased erosion and sedimentation may degrade water quality in local streams. Consumptive water withdrawals may alter instream habitat conditions, and project effluents could lead to an increase in total dissolved solids concentrations in downstream portions of the watershed. Toxic waste effluents, including point or nonpoint discharges and intermittent overflows from holding ponds, may result in either acute or chronic stress on plankton, macrophyte, benthic macro-invertebrate, or fish populations. 
Using general background information on the affected environment, onsite inventory data (the type and extent determined during early consultation), and the information on the project design, the analysis should:

- describe the terrestrial and aquatic biota affected by the proposed project, with special attention paid to endangered, threatened, rare, or otherwise protected plant and animal species;

- characterize by dominant species and physical features all terrestrial and aquatic habitats that will be disturbed;

- estimate the number of hectares of each type of habitat that will be disturbed during mining, construction, and operation;

- present a reclamation plan for all disturbed areas (Sect. 3.3.8);

- evaluate the effects of the composite toxicity of individual waste effluents, and, where applicable, combined waste effluents on target species of plants, invertebrates, and fish; and

- include information from initial contacts with state and federal fish and wildlife agencies and conservation personnel (formal consultation with the U.S. Fish and Wildlife Service in relation to the status of federally listed threatened and endangered species is the responsibility of federal action agency).

\subsubsection{Noise}

Because much of the tar sand area is remote and undeveloped and has a high recreational value, project-induced noise levels may cause a significant impact. Surface mining will require blasting in the consolidated formations of Utah. Heavy machinery and traffic on haul roads may be a significant source of noise. Operations at the separation and upgrading facilities may produce noise levels in excess of $100 \mathrm{dBA}$ in the plant vicinity (Norman and Norman 1978).

Estimates of the level of noise produced by project activities should be supplied. Information on the level of sensitivity and the 
distance to nearby sensitive receptors (e.g., recreational areas, backpacking trails, or residential areas) should also be provided.

\subsubsection{Solid Waste Disposal}

Solid waste generated at all stages in tar sand processing should be accounted for. Sources of solid wastes include:

- spent mineral tailings separated from bitumen,

- coal or shale in overburden handled but discarded in the mining process,

- $\quad$ sludge produced in waste treatment processes,

- fly and bottom ash from boilers,

- $\quad$ spent catalysts used in upgrading processes, and

- conventional domestic solid wastes.

The environmental analysis should identify all the types of solid wastes that will be produced by the proposed project, indicate which wastes are hazardous and which are nonhazardous, estimate the quantities of each type of waste that will be produced on an annual basis and over the lifetime of the project, and describe the steps that will be taken to identify which of the wastes are hazardous and which are not. This section should clearly outline the proposed plans for disposal of both hazardous and nonhazardous wastes.

Disposal sites and methods for handling and treating wastes from each of the sources listed above should be identified. The design of onsite disposal areas should include the following considerations for the control and collection of leachates: the placement of liners in holding ponds to minimize seepage, construction of dikes and ditches to collect surface runoff and leachate, and the use of cover material over long-term storage or disposal sites. Reclamation plans (Sect. 3.3.8) outlining the long-term use of disposal sites should also be discussed.

Canadian experience has revealed several problems associated with disposal of tar-sand tailings (deNevers et al. 1979). Colloidal materials associated with tailings from surface-mined tar sand have 
very slow settling velocities. Evaporation rates from settling ponds can also be low, especially when surface films of residual organics accumulate. Effluents produced from settling pond overflows have been found to be toxic to fish and wildlife. Therefore, special attention should be devoted to design of tailings ponds to reduce the probability of water quality impacts.

\subsubsection{Reclamation}

Reclamation of mined 1 and and disposal areas is a major problem area in any tar sand operation. Plans for reclamation should be described in detail. The objectives of reclamation should be to (1) reduce water and wind erosion from the disturbed landscape, restore the disturbed areas to productive use, and (3) ensure that long-term contamination of ground and surface waters by leachates from the reclaimed areas does not occur.

The reclamation plan should include all areas disturbed during construction and operation of the proposed facility and describe:

- the location of all areas to be reclaimed (a map should be provided);

- handling and storage of topsoil;

- soil amendments to be used;

- irrigation plans and water sources;

- cover species to be used.

- measures to protect the reclaimed areas from grazing for sufficient time to allow establishment of new vegetation;

- a monitoring program to evaluate long-term success of reclamation; and

- schedule for implementation of specific portions of the plan. 


\subsubsection{Socioeconomics}

The majority of the tar sand resource is located in areas characterized by small isolated communities. Boomtown effects on small communities resulting from a rapid and large population influx have been demonstrated in the western coal regions (Gilmore and Duff 1975). Housing and municipal services in small communities are often insufficient to handle large population increases (Cortese and Jones 1979). Tax revenues from the energy facilities lag several years behind the rise in local government expenditures required to meet increased demand for services and may not reach all, or even most, of those jurisdictions experiencing project-induced impacts. High-paying energy jobs draw labor away from lower-paying local employers, and local inflation may occur, causing particular damage to low income residents and those on fixed incomes. Rapid population increases may be accompanied by cultural disruptions and a rise in crime rates. Population increase can also exacerbate effects from the energy development itself on air quality, water availability and quality, and surrounding natural habitats.

Boomtown effects should be anticipated as a result of large tar sand development in eastern Utah and to a lesser extent in other areas. Effects from development of tar sand resources may also be cumulative with those of other nearby energy developments such as oil shale, uranium, and coal exploitation. Adverse effects could be especially critical in areas of southeast Utah where population increases from both tar sand and other energy developments could affect communities with populations of fewer than 5000 people.

Water supply (Sect. 3.3.3) may be especially critical because there is little water in many areas of the west, and energy extraction processes often consume significant amounts of water. Frazier et al. (1976) note that degradation of water quality will result from surface mining of $\operatorname{tar}$ sand and that some in situ technologies will require substantial amounts of ${ }^{\circ}$ water. Although some of this water may be processed and reused, the water demands associated with the development 
of tar sand projects may have adverse effects on local communities and the quality of life in the impact region.

The analysis of socioeconomic impacts should include projections and/or analyses of the following information:

- rate and magnitude of population increase during construction and operation of the project, and probable residential location of in-movers;

- capacity of existing and planned housing stock to accommodate project-induced housing demand in affected communities;

- the amount and timing of increased revenues and expenditures for the impacted jurisdictions as a result of project-related growth;

- adequacy of local transportation networks to handle increased worker and heavy equipment traffic;

- adequacy of local public services (e.g., water supplies and domestic waste treatment systems) to serve expected increased populations in affected communities.

- direct and secondary employment to be created by the proposed project and project-induced changes on the local economic character;

- impacts on structure and management of local government and major local organizations;

- impacts to existing life-style, cultural, and ethnic characteristics of the impact region; and

- local support or opposition to the proposed project.

The assumptions used for the projections and/or analyses listed above (e.g., the multipliers used) should be discussed. In addition, the environmental analysis should include plans for monitoring and mitigation.

\subsubsection{Health and Safety}

Although commercial utilization of tar sand in Canada has occurred since 1968, there are little or no available toxicological or bioassay 
data available, nor is there any published documentation of industrial hygiene programs. Jackson (1979) and MacFarland (1979) briefly discuss the occupational health and safety problems that will most likely be associated with the processing of tar sand to produce synthetic crude 0i1. The product is essentially a heavy petroleum, and potential health hazards appear to be similar to those found in refining crude petroleum oil or coal conversion and oil shale recovery processes.

Mining of tar sand will result in occupational hazards much like those associated with open-pit or strip mining. Increased dust levels and noise from heavy equipment will be inherent in the mining operations. Although sand grains composed of 40 to $50 \%$ silicon comprise about $83 \%$ of the weight of tar sand, the sticky nature of the sand will help to reduce dust levels during mining. However, after the bitumen has been removed from the sand during reclamation or disposal, increased dust levels and resulting exposure to silica may be experienced (Jackson 1979). The development of silicosis, chronic bronchitis, and other respiratory disorders as a result of silica dust exposures cannot be discounted, and dust levels must be evaluated critically during mining and disposal.

Various process streams of tar sand retorting facilities as well as the resulting crude oil may contain known mutagens and carcinogens such as aliphatic or aromatic hydrocarbons. Dermal contact with these materials should be avoided.

Fractional distillation, used to separate product fractions by boiling point, is accompanied by the use of catalysts to obtain the desired products. Benzene, now regarded as a carcinogen thought to produce leukemia at high exposure levels, may be present during this process, as well as $\underline{n}$-hexane, which may induce peripheral neuropathy following systemic absorption (McFarland 1979). Exposures to carbon monoxide, naphtha vapors, and metal-catalyst carbonyls during extraction, coking, and hydrotreating present potential health hazards. Because tar sand contains up to $6 \%$ organically bound sulfur, 
the escape of hydrogen sulfide during refining processes is a hazard that must be assessed (Jackson 1979). Workers may also be exposed to heat, noise, high pressure steam, and coke dust (McFarland 1979).

The major solid waste produced will be sand that may be coated with a layer of coke produced in the retort. This sand may be returned to the mined-out area. No data were found on releases from tar sand retorting processes that would permit a discussion of potential public health concerns. Releases of $\mathrm{SO}_{x}, \mathrm{NO}_{x}$, some particulates, and trace elements are possible.

The analysis should address those health and safety issues that are of concern and should include plans for minimizing the risk to workers and the public. Any monitoring programs should be clearly described. 


\subsection{REFERENCES}

Anonymous. 1975. New Cold Lake pilot onstream. $0 i 1$ Week 26(35):58-59.

Ball and Associates. 1975. Surface and shallow oil-impregnated rocks and shallow oil fields in the United States. Monograph 12. U.S. Bureau of Mines, Washington, D.C.

Baughman, G. L. 1978. Synthetic Fuels Data Handbook. Second Edition. Cameron Engineers, Inc., Denver, Colorado.

Cortese, C. F., and B. Jones. 1979. Energy boomtowns. pp. 101-163. IN Sociopolitical Effects of Energy Use and Policy. Committee on Nuclear and Alternative Energy Systems, National Academy of Sciences, Washington, D.C.

Cupps, C. Q., C. S. Land, and L. C. Marchant. 1975. Laramie Energy Research Center field experiment of in situ oil recovery from a Utah tar sand by reverse combustion. Paper presented at AIChE Meeting. Laramie Energy Research Center, Laramie, Wyoming.

deNevers, N., B. Glenne, and C. Bryner. 1979. Analysis of the environmental control technology for tar sand development. C00-404. U. S. Department of Energy, Washington, D.C.

Doscher, T. M. 1967. Technical problems in in situ methods for recovery and bitumen from tar sands. pp. 625-632. IN 7th World Petroleum Congress, Vol. 3. Elsevier Publishing Company, New York.

Frazier, N. A., D. W. Hissong, W. E. Ballentine, and E. J. Mazey. 1976. Production and processing of U.S. tar sands: An environmental assessment. EPA-600/7-76-035. U.S. Environmental Protection Agency, Industrial Environmental Research Laboratory, Cincinnati, ohio.

Gilmore, J. S., and M. K. Duff. 1975. Boomtown Growth Management: A Case Study of Rock Springs - Green River, Wyoming. Westview Press, Boulder, Colorado.

Jackson, J. 0. 1979. Comparative industrial hygiene aspects for coal gasification and liquefaction, oil shale, and $\operatorname{tar}$ sands processing. pp. 266-276. IN K. E. Cowser and C. R. Richmond, (eds.), Proc. Symposium on Potential Health and Environmental Effects of Synthetic Fossil Fuels. CONF-780903. Oak Ridge National Laboratory, Oak Ridge, Tennessee. 
Johnson, L. A., Jr., L. J. Fahey, and L. J. Romanowski, Jr. 1981. A steamflood experiment in a Utah tar sand. pp. 145-149. IN Proc. California Regional Meeting, Society of Petroleum Engineers of AIME. Paper No. SPE 9900. American Institute of Mining Engineers, New York.

Kuuskraa, V. A., S. Chalton, and T. M. Doscher. 1978. The economic potential of domestic tar sands. HCP/T9014-01. U.S. Department of Energy, Washington, D.C.

Land, C. S., F. M. Carlson, and C. Q. Cupps. 1975. Laboratory investigation of reverse combustion in two Utah tar sands. LERC/RI-75/2. Laramie Energy Research Center, Laramie, Wyoming.

Land, C. S., C. Q. Cupps, L. C. Marchant, and F. M. Carison. 1977. Field experiment of reverse combustion oil recovery from a Utah tar sand. LERC/RI-77/5. Laramie Energy Research Center, Laramie, Wyoming.

Lindberg, W. R. 1980. Tar sand extraction by steam stimulation and steam-drive measurement of physical properties. LETC/TPR-801761. Laramie Energy Technology Center, Laramie, Wyoming.

MacFarland, H. N. 1979. Alternate fuels can damage health. Hydrocarbon Process 58(5):150-151.

Maugh, T. H., II. 1978. Tar sands: A new fuels industry takes shape. Science 199:756-760.

McRae, P., J. L. Dudas, and H. Rowland. 1977. The Energy Source Book. Center for Compliance Information, Aspen Systems Corporation, Germantown, Maryland.

Norman, N. A., and N. A. Norman. 1978. Environmental aspects of the syncrude tar sands project. IN A. E. St. Clair (ed.), Proc. American Nuclear Society Conference on Environmental Aspects of Non-Conventional Energy Resources - II. American Nuclear Society, LaGrange, Illinois.

U.S. Bureau of Mines. 1972. Extraction of energy fuels. BUMINES-OFR30-73. Federal Council for Science and Technology, Extraction of Energy Fuels Panel, Washington, D.C.

U.S. Department of Energy (U.S. DOE). 1979. U.S. tar sand 011 forecasts. DOE/EIA-0183/15. Washington, D.C.

U.S. Environmental Protection Agency (U.S. EPA). 1976. Production and processing of U.S. tar sands: An environmental assessment. EPA-600/7-76-035. Washington, D.C. 


\section{COAL GASIFICATION AND LIQUEFACTION}

Michael J. Sale, ${ }^{1}$ Roger L. Kroodsma, ${ }^{1}$ and Martin Schweitzer ${ }^{2}$

\subsection{RESOURCE DESCRIPTION}

In terms of volume and gross energy potential, coal is the most significant fossil fuel resource in the United States. Coal reserves constitute about 90\% of the nation's fossil fuel reserves (Parker and Thompson 1976, U.S. GAO 1977) and are widely distributed (Fig. 4). Use of this important natural resource has, in the past, been limited by problems such as mining impacts, transportation of the product to the markets, and environmental pollution. Although mining and transportation problems can be largely solved with existing technology, environmental issues such as potential air and water pollution are persistent problems (U.S. DOE 1978a,b; Braunstein et al. 1977a).

Coal-derived synfuels (CDS) can be produced by gasification and/or liquefaction, conversion processes that transform coal from its original, heterogeneous form (Table 8 ) into more homogeneous gaseous, liquid, or solid products. The intent of creating synfuels from coal is threefold: (1) to develop alternative energy sources that are compatible with existing environmental protection criteria, (2) to increase the use of domestic energy supplies consistent with the national goal of energy independence, and (3) to produce fuels that are compatible with existing delivery systems and markets. These objectives can be met by isolating the hydrocarbon fraction of coal, enriching the hydrogen to carbon ratio of the products relative to the raw material, and removing undesirable inorganic constituents such as

\footnotetext{
$T_{\text {Environmental Sciences Division, ORNL. }}$ ${ }^{2}$ Energy Division, ORNL.
} 
ORNL-DWG 82-15166

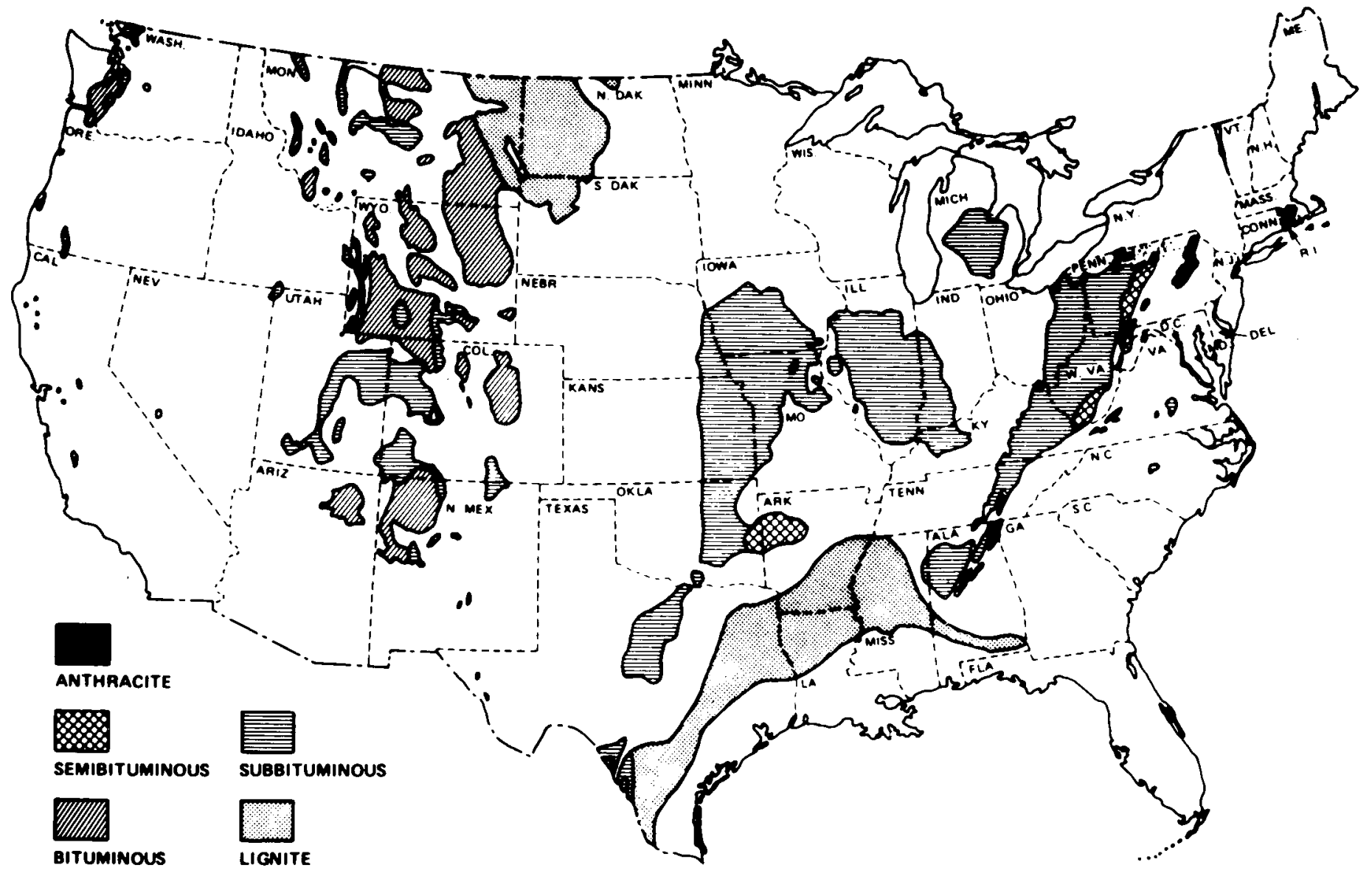

Fig. 4. Geographic distribution of coal deposits in the United States (U.S. DOE 1979). 
Table 8. Mean analytical values for 101 coal types.

\begin{tabular}{|c|c|c|c|c|}
\hline & Mean & $\begin{array}{l}\text { Standard } \\
\text { deviation }\end{array}$ & Minimum & Maximum \\
\hline 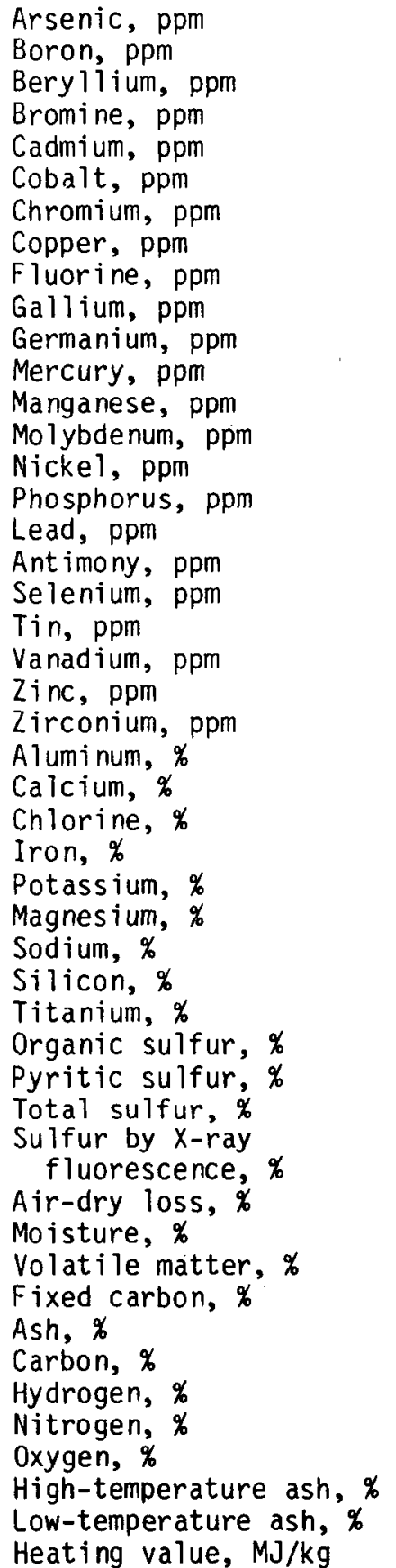 & $\begin{array}{r}14.02 \\
102.21 \\
1.61 \\
15.42 \\
2.52 \\
9.57 \\
13.75 \\
15.16 \\
60.94 \\
3.12 \\
6.59 \\
0.20 \\
49.40 \\
7.54 \\
21.07 \\
71.10 \\
34.78 \\
1.26 \\
2.08 \\
4.79 \\
32.71 \\
272.29 \\
72.46 \\
1.29 \\
0.77 \\
0.14 \\
1.92 \\
0.16 \\
0.05 \\
0.05 \\
2.49 \\
0.07 \\
1.41 \\
1.76 \\
3.27 \\
2.91 \\
7.70 \\
9.05 \\
39.70 \\
48.82 \\
11.44 \\
70.28 \\
4.95 \\
1.30 \\
8.68 \\
11.41 \\
15.28 \\
29.65\end{array}$ & $\begin{array}{r}17.70 \\
54.65 \\
0.82 \\
5.92 \\
7.60 \\
7.26 \\
7.26 \\
8.12 \\
20.99 \\
1.06 \\
6.71 \\
0.20 \\
40.15 \\
5.96 \\
12.35 \\
72.81 \\
43.69 \\
1.32 \\
1.10 \\
6.15 \\
12.03 \\
694.23 \\
57.78 \\
0.45 \\
0.55 \\
0.14 \\
0.79 \\
0.06 \\
0.04 \\
0.04 \\
0.80 \\
0.02 \\
0.65 \\
0.86 \\
1.35 \\
1.24 \\
3.47 \\
5.05 \\
4.27 \\
4.95 \\
2.89 \\
3.87 \\
0.31 \\
0.22 \\
2.44 \\
2.95 \\
4.04 \\
1.08\end{array}$ & $\begin{array}{r}0.50 \\
5.00 \\
0.20 \\
4.00 \\
0.10 \\
1.00 \\
4.00 \\
5.00 \\
25.00 \\
1.10 \\
1.00 \\
0.02 \\
6.00 \\
1.00 \\
3.00 \\
5.00 \\
4.00 \\
0.20 \\
0.45 \\
1.00 \\
11.00 \\
6.00 \\
8.00 \\
0.43 \\
0.05 \\
0.01 \\
0.34 \\
0.02 \\
0.01 \\
0.00 \\
0.58 \\
0.02 \\
0.31 \\
0.06 \\
0.42 \\
0.54 \\
1.40 \\
0.01 \\
18.90 \\
34.60 \\
2.20 \\
55.23 \\
4.03 \\
0.78 \\
4.15 \\
3.28 \\
3.82 \\
26.89\end{array}$ & $\begin{array}{r}93.00 \\
224.00 \\
4.00 \\
52.00 \\
65.00 \\
65.00 \\
54.00 \\
61.00 \\
143.00 \\
7.50 \\
43.00 \\
1.60 \\
181.00 \\
30.00 \\
80.00 \\
400.00 \\
218.00 \\
8.90 \\
7.70 \\
51.00 \\
78.00 \\
5350.00 \\
133.00 \\
3.04 \\
2.67 \\
0.54 \\
4.32 \\
0.43 \\
0.25 \\
0.20 \\
6.09 \\
0.15 \\
3.09 \\
3.78 \\
6.47 \\
5.40 \\
16.70 \\
20.70 \\
52.70 \\
65.40 \\
25.80 \\
80.14 \\
5.79 \\
1.84 \\
16.08 \\
25.85 \\
31.70 \\
33.41\end{array}$ \\
\hline
\end{tabular}

SOURCE: Ruch et al. 1974 . 
sulfur, trace metals, and other inert materials. The synthetic products which can be generated include:

- high, intermediate, or low Btu gases;

- liquids such as naphtha, methanol, gasoline, diesel oil, or No. 2 and No. 6 fuel oils; and

- low-melting-point solids for use as boiler fuel with low-sulfur, low-ash content.

Other commercially valuable by-products that can be obtained through the production of CDS include ammonia, elemental sulfur, phenol, and coke.

Depending on their chemical composition, gaseous synfuels fall into one of three heating value classifications. Low Btu gas, also called synthesis gas, consists primarily of hydrogen $\left(\mathrm{H}_{2}\right)$, carbon monoxide ( $\mathrm{CO}$ ), and nitrogen gas species; its heating value is less than $7.5 \mathrm{MJ} / \mathrm{m}^{3}$ (approximately $200 \mathrm{Btu} / \mathrm{scf}$ ). Intermediate Btu gas has comparatively more methane $\left(\mathrm{CH}_{4}\right)$ and less nitrogen than does low Btu gas. Heating values of intermediate Btu gas range up to $17 \mathrm{MJ} / \mathrm{m}^{3}$ (approximately $450 \mathrm{Btu} / \mathrm{scf}$ ). Intermediate and low Btu gases contain significant amounts of impurities such as hydrogen sulfide $\left(\mathrm{H}_{2} \mathrm{~S}\right)$, carbon dioxide $\left(\mathrm{CO}_{2}\right)$, hydrogen cyanide $(\mathrm{HCN})$, phenols, and higher molecular weight hydrocarbons. Direct uses of these coal gases are primarily in local industry as boiler feeds. Synthesis gas, however, is more commonly used as the precursor for the production of higher grade synfuel or as a chemical feedstock (i.e., source of $\mathrm{H}^{2}$ and/or CO for production of ammonia or other petrochemicals).

High Btu gas, which is almost pure $\mathrm{CH}_{4}$, has a heating value of greater than $33 \mathrm{MJ} / \mathrm{m}^{3}(900 \mathrm{Btu} / \mathrm{scf})$. Substitute pipeline gas (SPG), a high Btu gas suitable for distribution within existing natural gas pipeline systems, is an example of this type of CDS. Because strict quality standards exist for allowable concentrations of carbon monoxide, carbon dioxide, hydrogen sulfide, total sulfur, water vapor, and higher molecular weight hydrocarbons in SPG (Strakey et al. 1975), 
plants producing SPG include additional processes to remove these impurities.

The syncrudes from which liquid CDS products are refined differ from petroleum crude $0 i 1$ in several important ways. Although the original coal type and the specific conversion process determine syncrude characteristics, coal-derived syncrudes are generally higher in nitrogen, sulfur, cyclic hydrocarbons, and trace elements than is petroleum crude oil. Coal syncrudes can be hydrotreated to produce a CDS compatible with standard oil-refining techniques (NAS 1977, Sullivan et al. 1981). However, the concentrations of polycyclic aromatic hydrocarbons (PAHs) and acidic organic compounds such as phenols and cresols will still exceed those in petroleum products, especially in heavier CDS products (Braunstein et a1. 1977a).

An example of solid-phase CDS products is the low-sulfur, low-ash, solid fuel synthesized by the Solvent Refined Coal (SRC-I) process (U.S. DOE 1981b). This synfuel has been demonstrated to be as acceptable a boiler feedstock as coal (Bechtel National, Inc. 1979). The SRC solids have less than $0.96 \%$ sulfur and $0.16 \%$ ash. Heating values are about $37 \mathrm{MJ} / \mathrm{kg}(16,000 \mathrm{Btu} / \mathrm{lb})$, higher than the original coa1. The major benefits of retrofitting power plants to use SRC solids are the decreased atmospheric emissions which result from using this cleaner burning fuel.

A large number of design variations among specific CDS projects are possible, depending on the desired end products and the conversion strategy used. While the distinction between coal gasification (production of gaseous synfuels) and liquefaction (production of liquid synfuels) is clear, the route that can be taken to produce any one particular CDS is far from unique (Fig. 5). For example, SPG can be produced via coal gasification followed by methanation, or it $c$ an be a secondary product of a liquefaction scheme, being produced from coal char left over from pyrolysis or solvation processes of liquefaction (the previously proposed ICGG project in southern Illinois was an example of the latter). Similarly, gasoline can be produced by refining naphtha produced in a direct liquefaction process (e.g., 
ORNL-DWG B2-15167

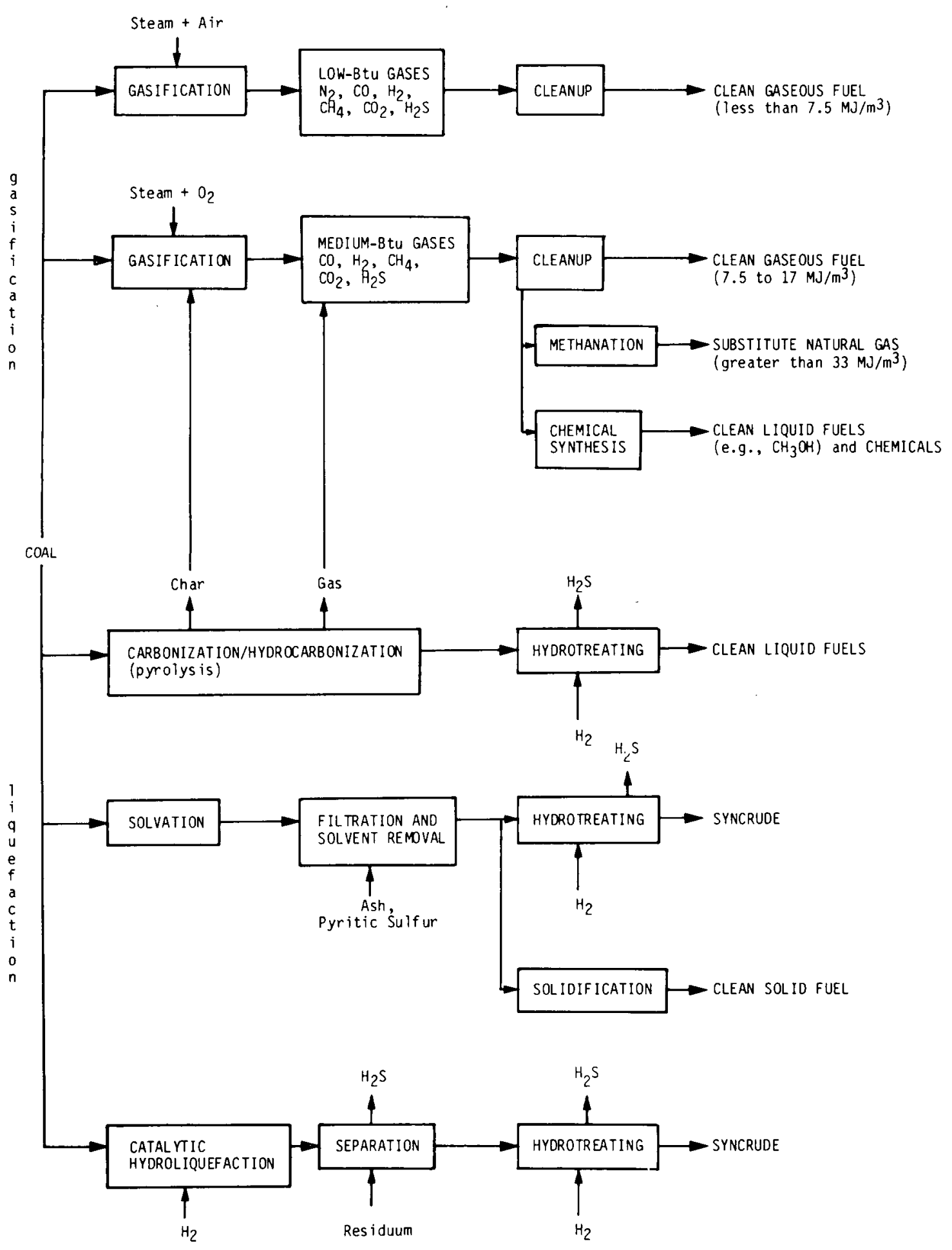

Fig. 5. Alternative processes for synfuel production from coal (modified from Gehrs 1977). 
SRC II), or it can be derived indirectly by catalytic reformation of methanol produced from synthesis gas (hence the term "indirectliquefaction"). When gasification and liquefaction are used to supplement each other (e.g., where the hydrogen gas required in hydrogenation reactions of liquefaction is produced onsite by a parallel gasification process), CDS project design is complicated further. Economic pressure to increase the conversion efficiency of synfuel production may lead to an increased number of projects incorporating both gasification and liquefaction processes into the same coal conversion scheme.

\subsection{TECHNOLOGY OVERVIEW}

\subsubsection{Coal Gasification}

The central element in all gasification design schemes is a reactor vessel called the gasifier in which the initial carbon monoxide/hydrogen synthesis gas mixture is produced from coal or coal char. The gasifier is usually a high temperature, pressurized vessel where both combustion (Table 9, Eq. 1) and gasification (Table 9, Eq. 2) occur. Gasifier designs are divided into three types, depending on the method used to introduce the coal feed into the reactor. Fixed bed gasifiers support input coal on rigid rack systems and pass gases over the bed at low velocities. Fluidized-bed gasifiers operate with high gas velocities (usualiy upflow) and small coal particle sizes in such a way that the solid particles are freely suspended. Entrainedbed gasifiers also use a high velocity stream of oxidant (air or $0_{2}$ ) and steam to carry coal particles into the reactor vessel but fluidization velocities are not maintained.

other important variables in gasifier design are the temperature and pressure conditions and oxidant type. High pressure aids the hydrogasification reaction (Table 9, Eq. 3), which produces synthesis gas with a relatively higher heating value (more $\mathrm{CH}_{4}$ ). Use of pure oxygen as the oxidant in place of air also produces a higher grade product because the resultant heating values are not depressed by the 
Table 9. Principal chemical conversions involved in coal-derived synfuels production

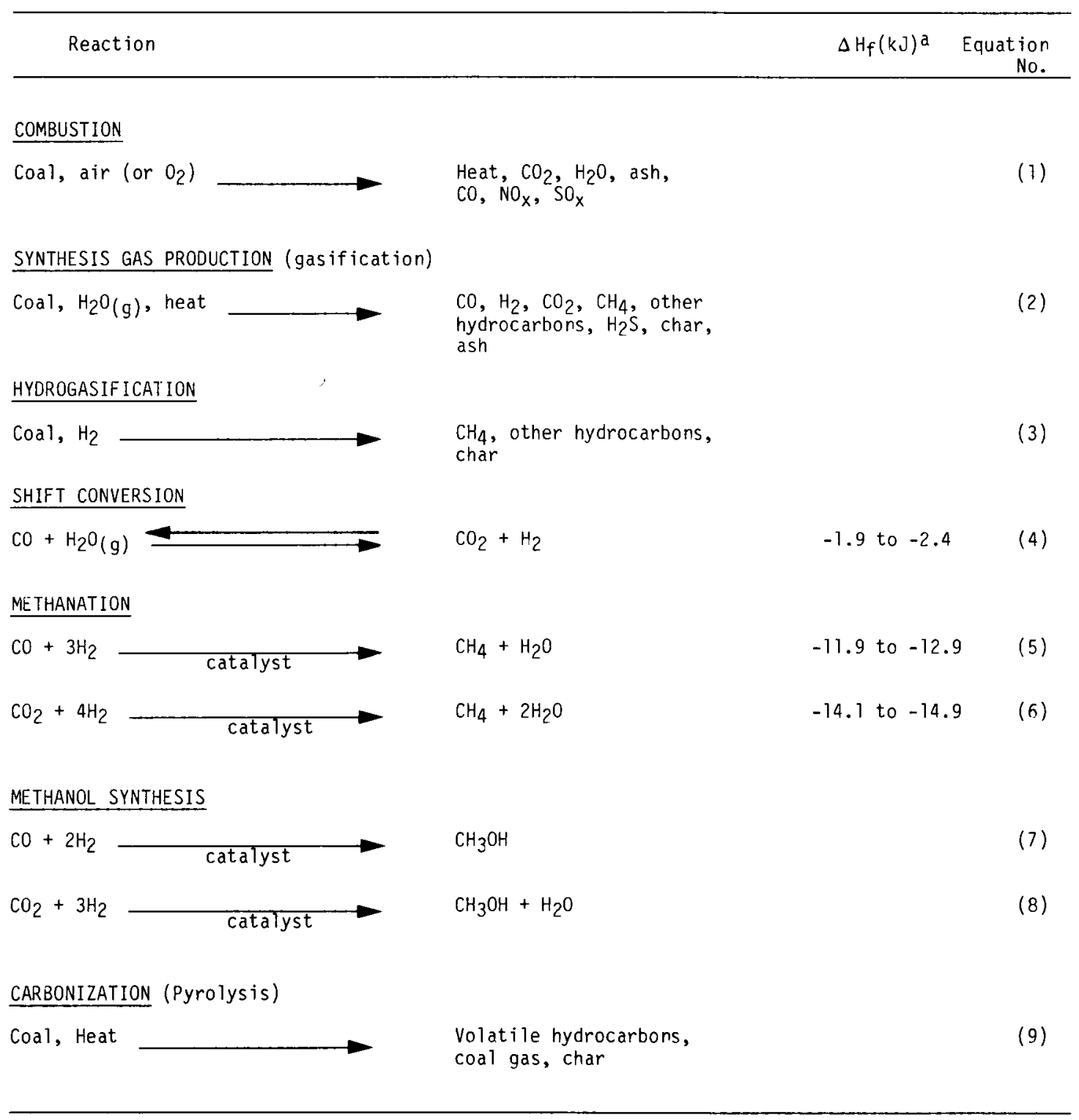

$a_{1} \mathrm{~kJ}=0.239 \mathrm{kcal}$. 
presence of nitrogen. A devolatilization gasifier emphasizes the hydrogasification reaction only by combining hydrogen and coal at high temperature and pressure in the absence of any oxidants.

The raw synthesis gases undergo a series of cleanup processes after leaving the gasifier. The first step is gas quenching, which consists of passing the gas stream through a spray of water forcing condensation and removal of nongaseous by-products. The aqueous waste stream from quenching (i.e., process condensate) contains oils, tars, phenolics, polycyclic aromatic hydrocarbons (PAHs), and entrained ash particles. The gaseous product stream after quenching contains the desired $\mathrm{CO}, \mathrm{H}_{2}$, and $\mathrm{CH}_{4}$ plus impurities such as $\mathrm{H}_{2} \mathrm{~S}$ that must be removed before further processing of the synthesis gas.

Acid gas removal is a unit process used to purge undesirable sulfur compounds and carbon dioxide. The operation is carried out by either physical or chemical absorption of acidic gases into either a liquid phase or solid precipitate. Absorption liquids include hot carbonate, methanol, amine solutions, and dimethoxy tetraethylene glycol. A filter bed of iron or zinc oxides can also be used to remove $\mathrm{H}_{2} \mathrm{~S}$. The sour (acidic) liquid waste streams from this process are routed through a regenerator, recycled to a wastewater treatment process, or used in another stage in the conversion scheme (e.g., gas quenching). Acid gas removal in the gasification scheme can be done either before or after the shift conversion reaction, but it must precede any catalytic processes because $\mathrm{H}_{2} \mathrm{~S}$ inactivates most catalyst beds critical in later conversion processes.

The shift conversion process (Table 9, Eq. 4) is an intermediate step essential to optimize the catalytic conversions that produce $\mathrm{CH}_{4}$ or methanol $\left(\mathrm{CH}_{3} \mathrm{OH}\right)$. The reaction consists of saturating a CO-rich gas with steam and passing it through a catalytic reactor (e.g., chromium or iron oxide) to produce $\mathrm{H}_{2}$ and $\mathrm{CO}_{2}$. Carbon dioxide can then be removed in an acid wash step to result in a net change in $\mathrm{H}_{2}: \mathrm{CO}$ ratios. The presence of a catalyst is most important at lower temperatures (e.g., less than $370^{\circ} \mathrm{C}$ ) to force the reaction to equilibrium. Usually only part of the purified synthesis gas stream 
undergoes shift conversion to produce sufficient $\mathrm{H}_{2}$ for subsequent catalytic conversion reactions. Optimal molar ratios of $\mathrm{H}_{2}$ to $\mathrm{CO}_{2}$ are $3: 1$ for methanation and $2: 1$ for methanol production. Shift conversions will generate a minor aqueous waste stream consisting of excess water and a small amount of condensed hydrocarbons.

Methanation is the last major step in the production of SPG. Effective catalysts for the methanation reactions (Table 9, Eqs. 5 and 6) are ruthenium, nickel, cobalt, iron, or molybdenum (Strakey et al. 1975). Deactivation and fouling of the catalysts is a serious problem. Because the reactions producing $\mathrm{CH}_{4}$ are highly exothermic, cooling of the methanation reactor is required to keep temperatures in a range to maintain long catalyst life. Poisoning by sulfur compounds can occur if inflow gases have not been cleaned. Careful control over pressure and $\mathrm{H}_{2}: \mathrm{CO}_{2}$ ratios is necessary to avoid heterogeneous decomposition to $\mathrm{CO}$ and $\mathrm{CH}_{4}$ and the formation of elemental carbon deposits that result in catalyst fouling.

\subsubsection{Coal Liquefaction}

The overall objectives of coal liquefaction are the same as coal gasification: isolation of the hydrocarbon fraction of the raw coal feedstock and enrichment of the hydrogen-to-carbon ratios in liquid CDS products (NAS 1977). Conversion processes differ only in terms of emphasizing different types of endproducts. In addition to the indirect liquefaction schemes which operate on synthesis gas feedstocks (Salmon et al. 1980), three general techniques are available for direct coal liquefaction (Fig. 5; NAS 1977, Braunstein et al. 1977a): (1) carbonization (pyrolysis) or hydrocarbonization (pyrolysis in a hydrogen-enriched atmosphere), (2) solvation, and (3) catalytic hydroliquefaction (hydrogenation). The last two processes use solvent extraction. However, catalytic hydroliquefaction includes the addition of catalysts to the initial reaction process to enhance rates of hydrogenation. 
Liquefaction schemes based on pyrolysis (Table 9, Eq. 9) accomplish the thermal decomposition of coal by heating it in the absence of an oxidizing atmosphere (air or $\mathrm{O}_{2}$ ). The initial products are a complex mixture of volatile hydrocarbons condensed from pyrolysis gases, purified coal gases, and a high carbon char. Elevated $\mathrm{H}_{2}$ concentrations in the pyrolysis reactor help stabilize radical hydrocarbons and increase final $\mathrm{H}: \mathrm{C}$ ratios in the products. However, the liquid products from pyrolysis reactors are generally lower in both quantity and quality compared with those derived from other liquefaction schemes (NAS 1977). Although the operating temperatures and pressures are less severe in the carbonization processes than those in other types of liquefaction, and the overall designs are less complex, major problems remain to be solved, including wear and erosion of valves and piping, entrained-flow reactor plugging due to agglomeration of coals, and coal caking in fluidized-bed reactors.

Liquefaction schemes using solvation techniques begin by mixing crushed coal with an organic solvent. This slurry is then pumped to a pressurized $(13.8-17.2 \mathrm{MPa})$ and heated $\left(425-480^{\circ} \mathrm{C}\right)$ reaction vessel where it is mixed with hydrogen gas and the coal materials are dissolved. During this process, a combination of mild pyrolysis and hydrogenation takes place. In many process designs, the solvent serves a secondary purpose of being a hydrogen donar to radical hydrocarbons (the Exxon Donar Solvent process; Epperly et al. 1981). A filtration step is necessary after the coal/solvent mixture leaves the dissolution reactor to recover the solvent for recycle and to remove ash and other unconverted coal particles from the coal liquids. This solids separation process has caused many design problems (e.g., persistent clogging) due to the difficulty in separating solids from the very viscous mixture of hydrocarbons.

Catalytic hydrogenation can use catalysts in two different methods to increase the quality (i.e., lower boiling point and viscosity and higher $H: C$ ratios) of initial CDS products. The use of catalysts usually requires higher pressures in the liquefaction reactor than any 
other liquefaction designs (e.g., the H-Coal process operates at pressures in the region of $20.7 \mathrm{MPa}$ (3000 psig); Eccles and DeVaux 1981). These higher pressures increase equipment wear and cause more difficulty in introducing the coal-slurry feed into the liquefaction reactor. Catalysts can be either mixed directly with the crushed coal, transported into the liquefaction reactor, and discarded after the solids separation step (e.g., the Dow liquefaction process; Moll et al. 1981), or located in a fixed position inside the liquefaction reactor (e.g., the H-Coal process; Eccles and DeVaux, 1981).

Indirect liquefaction of coal is more analogous to high-Btu gasification processes than direct liquefaction processes (C. F. Braun \& Co. 1979, Salmon et al. 1980, Wham et al. 1981). Synthesis of $\mathrm{CH}_{3} \mathrm{OH}$ or gasoline is the most frequent objective of indirect liquefaction. The process flow proceeds from coal to synthesis gas to $\mathrm{CH}_{3} \mathrm{OH}$ (Table 9, Eqs. 1-7 and 1-8) and, if desired, gasoline or other reformed hydrocarbons. The $\mathrm{CH}_{3} \mathrm{OH}$ synthesis reactions occur in pressurized, catalytic reactors similar to those used in methanation, but different catalysts (e.g., zinc-chrome or copper-zinc combinations), higher pressures [often greater than $10 \mathrm{MPa}(100 \mathrm{~atm})$ ], and synthesis gas with $\mathrm{H}_{2} /\left(\mathrm{CO}+\mathrm{CO}_{2}\right)$ ratios only slightly greater than 2 are necessary to optimize the $\mathrm{CH}_{3} \mathrm{OH}$ synthesis reactions (Salmon et a1. 1980). As with methanation, the conversion reactions are exothermic and have significant cooling requirements. Simple condensation and distillation systems purify the crude methanol produced. Although a synthesis gas feedstock can come from any coal gasification process, recent studies indicate that entrained-bed gasifiers with high operating pressures are more suitable for coupling with $\mathrm{CH}_{3} \mathrm{OH}$ synthesis due to nigher flow-through volumes, higher $\mathrm{H}_{2} / \mathrm{CO}$ composition, less need for pressure changes between reactors, and smaller concentrations of undesirable by-products (Salmon et al. 1980). Fischer-Tropsch and M-Gasoline processes are two indirect liquefaction schemes with strong commercial potential that convert $\mathrm{CH}_{3} \mathrm{OH}$ into larger hydrocarbons by catalytic reformation (Rogers et a). 1978). 


\subsubsection{Auxiliary Processes}

The unit processes along the main conversion stream in CDS production (i.e., those processes directly linked to the gasifier and liquefaction reactors) constitute only part of an overall project design. Other important processes prepare raw materials for input to the main conversion stream, extract by-products, or treat the waste streams created in the various stages of coal conversion (Fig. 6). The design and operation of these auxiliary processes are as important to the evaluation of CDS projects as are the central gasification or liquefaction processes because they are involved in the use of raw materials and the removal of pollutants before they are released to the environment. To understand potential project impacts, each of these processes should be identified in a project flow diagram of inputs, outputs, and fates of waste constituents.

\subsection{POTENTIALLY SIGNIFICANT ISSUES}

Potentially significant environmental impacts associated with construction and operation of proposed CDS projects should be described in detail. In addition to addressing these issues, general background information on the affected environment should be reviewed to determine if any additional significant or controversial issues are apparent. For example, a review of this background information could show that an historic site is present on the project property and that portions of a 100-year floodplain could be affected. In such a situation, the applicant should upgrade the information and analysis as appropriate.

The following issues are those most likely to be significant for CDS projects and should be carefully reviewed. If this review shows that the issue is not relevant to the proposed project, then the reasons for not presenting a detailed analysis should be discussed.

\subsubsection{Land Use}

The types of information needed to assess the impacts of CDS projects on land use are generally similar to those needed for any other project involving construction and operation of a large-scale 
ORNL-DWG 82-15263
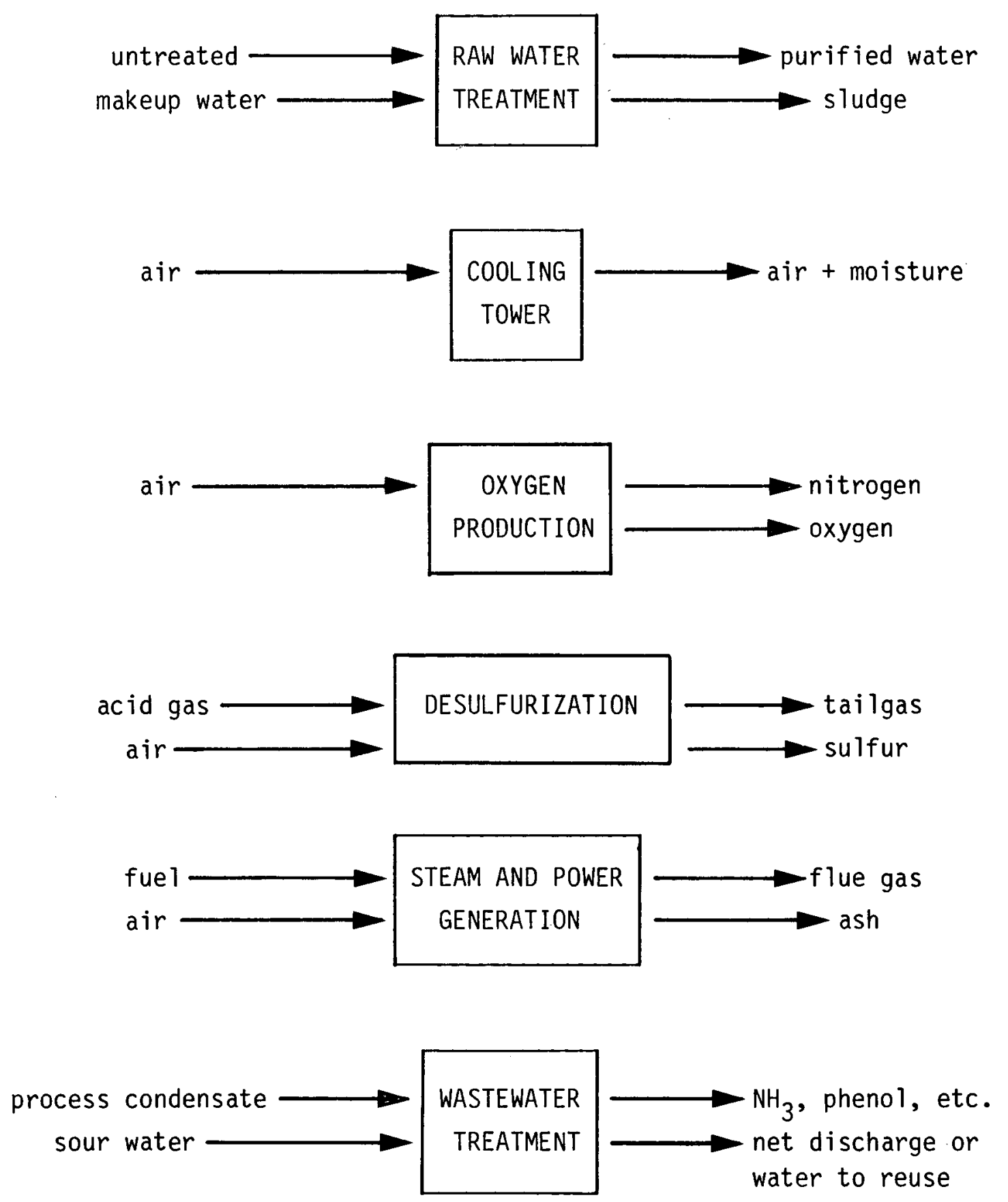

Fig. 6. Examples of auxiliary processes supporting the main coal-derived synfuels production process. 
facility. Land-use impacts of CDS facilities can result from onsite activities, coal mining, construction of transmission lines and pipelines, solid waste disposal, product spills, and secondary urban growth. The need for coal conversion facilities to locate adjacent to navigable waters for barge facilities and process and cooling water may result in adverse impacts on river bottomlands, floodplains, wetlands, prime farmlands, and shorelines. However, it is possible for coal conversion plants to locate in uplands distant from navigable waters, and this alternative should be thoroughly explored.

The need for CDS plants to be located near coal mines can contribute to significant cumulative impacts on land use within coal mining regions. In addition, the large work force associated with the construction and operation of CDS plants usually requires temporary housing (e.g., mobile home parks) and residential developments that can cause land-use conflicts.

Gaseous and particulate emissions to the atmosphere from CDS operations could potentially alter agricultural land use through effects on crop plants. The environmental analysis should address the potential occurrence of such impacts by using data on projected atmospheric emission concentrations (Sect. 4.3.2) and known sensitivities of crop species grown in the area.

Information should be developed on the quantity of land area affected by onsite and offsite facilities, coal mining required to support plant operation, and disposal areas or land fills. Although the specific impacts of coal mining on land use are not normally considered in the environmental review of a CDS facility, general information should be provided on impacts associated with the opening of new mines to provide feedstock for the proposed facility. In addition, if the proposed facility is a mine-mouth operation, the environmental impacts, including those on land use, should be evaluated. Alternatives for reducing impacts on prime farmlands, wetlands, floodplains, and shorelines should be thoroughly discussed. 


\subsubsection{Air Quality}

Prediction of gaseous and particulate emissions from CDS facilities is currently somewhat conceptual because knowledge of plant designs and experience with the operation of large commercial plants are lacking. The analysis should draw on information from the technical literature and current operating data from functioning pilot, demonstration, and commercial facilities. The following reports and EISs are examples of references that should be consulted: U.S. EPA 1973, 1978a, 1978b; Acurex Corp. 1977; Murin et a1. 1980; PEDCO 1976; U.S. DOE 1981b,c,d.

Major air quality issues associated with coal conversion include degradation of air quality through the release of criteria and noncriteria pollutants including known carcinogens. Much research is needed to determine the effects of the CDS industry on air quality and the general public. The research needs have recently been documented for the Federal Interagency Committee on the Health and Environmental Effects of Energy Technologies (MITRE 1981a, 1981b).

Estimates should be made, if practicable, of a11 gaseous and particulate emissions including controlled emissions from stacks; cooling tower emissions (which may include process chemicals leaking into the cooling system and treated process "water" used as cooling tower makeup); fugitive emissions (e.g., leaks from pump seals, valves, etc.); emissions during product storage and shipping; and windblown dusts from coal piles, transported slag, and coal in transit both offsite and onsite. Estimates during plant startup and shutdown, routine operation, and upset and emergency conditions should be provided. The bases for the estimates (e.g., coal composition, control equipment efficiency, literature, assumptions) and any conservative biases employed in the calculations should be indicated. In many cases the existing impact statements on proposed CDS facilities (U.S. DOE 1981b,c,d) can serve as models of the specific types of information that should be presented. 
The following gaseous and particulate substances may be emitted from CDS facilities, and the best estimates of emissions for each should be provided (MITRE 1981b):

- criteria pollutants: oxides of sulfur and nitrogen, carbon monoxide, lead, nonmethane hydrocarbons, and total suspended particulates;

- inorganic gaseous pollutants (e.g., hydrogen cyanide, metal carbonyls, hydrogen sulfide, and other reduced species that may be produced, such as $\mathrm{AsH}_{3}, \mathrm{SbH}_{3}$, $\mathrm{PH}_{3}, \mathrm{H}_{2} \mathrm{Se}, \mathrm{H}_{2} \mathrm{Te}$, etc.);

- gaseous, particulate, and particulate-adsorbed organic pollutants [e.g., aromatics (benzene, etc.), polynuclear aromatics (with emphasis on nitrogen-containing or oxygen-containing PNAS), oxygen-containing organics (phenols, carbonyls, ethers, peroxides, acids, etc.), nitrogen-containing organics (amines, nitrosoamines, etc.), and sulfur-containing organics (carbonyl sulfide, etc.) ];

- size distribution of particulates;

- inorganic constituents of particulate matter: lead, cadmium, mercury, nickel, chromium, beryllium, thallium, tellurium, selenium, arsenic, molybdenum, aluminum, iron-containing compounds, fluorides, nitrates, silicates, sulfates, and sulfites; and

- thorium and uranium and their daughter products.

Ground-level concentrations of pollutants should be estimated by dispersion modeling for comparison with the appropriate national ambient air quality standards and guidelines. Estimates should be made for $\mathrm{SO}_{2}, \mathrm{NO}_{2}, \mathrm{CO}$, lead, nonmethane hydrocarbons, and total suspended particulates. Existing ambient levels of these pollutants based on monitoring at the site and at appropriate offsite monitoring stations should also be provided. Consumption of Prevention of Significant Deterioration (PSD) increments and effects on air quality in Class I, II, and III areas should be discussed, including consideration of interaction of emissions with those of other proposed facilities and facilities under construction in the region. 0zone, a 
secondary pollutant, and odors that may be a nuisance to the local populace should also be discussed.

The methods and equipment used to control emissions, their projected efficiencies, and a directed maintenance program to limit fugitive emissions should be described in detail. Alternatives considered should be indicated. The types of emissions resulting from end-use combustion and proposed monitoring of process streams and emissions should be described.

\subsubsection{Water Use}

Projects producing CDS will be consumers of significant amounts of water (e.g., Whitlach 1977). Estimates of net water consumption at proposed demonstration projects range from 2.5 to $3.6 \mathrm{~L} / \mathrm{kg}$ (600 to $860 \mathrm{gal} /$ ton) of coal processed (U.S. DOE 1981b,c,d). Goldstein and Yang (1977) projected slightly smaller net water demands for SRC projects in New Mexico and North Dakota, ranging from 0.8 to $1.2 \mathrm{~L} / \mathrm{kg}$ (190 to $330 \mathrm{gal} / \mathrm{ton}$ ) of coal processed. Although CDS projects may be located in regions not usually considered to be-water-resource limited, their direct and cumulative impacts can introduce new water demands that compete with existing water uses (e.g., Appendix CC in U.S. DOE 1981b or Fuessle et a1. 1978). Adequacy of local water supplies and the regional implications of new water uses must be carefully examined.

The water quantity requirements should be in sufficient detail to indicate water needs for specific consumptive and nonconsumptive categories of water use. Plans for meeting these requirements should then be identified in the form of a comprehensive water management plan (sources, sinks, and volumetric flow rates). Among the water-use categories that should be covered are the following:

- coal preparation and crushing,

- cooling,

- ash quenching and disposal,

- process make-up water, 
- scrubbing of off-gases (e.g., desulfurization),

- domestic consumption,

- fire protection,

- reservoir evaporation, and

- dust control.

In addition to flow diagrams, water management plans should specify the sources for satisfying the requirements of each water-use category. More specifically, information should be provided to identify:

- surface water sources to be utilized, including descriptive hydrology of the watershed and planned withdrawal rates;

- groundwater sources to be utilized, including aquifer description and safe yields;

- dependence of project water sources on the construction of related water development projects;

- interrelationships between groundwater sources utilized and surface water, other aquifers, or rechange zones which might be affected by the synfuel project; and

- institutional, legal, and political arrangements involved in obtaining water supplies, including documentation of appropriate water rights, entitlements, or permits.

The quality of water sources should be described to ensure that it meets project requirements. Necessary water treatment should be described. All opportunities for water recycling and conservation within the project design should be evaluated and should be emphasized in the consideration of these types of alternatives (Fig. 7). Zero-effluent operations that maximize water reuse are desirable both in terms of reducing impacts on ambient water quality and conserving regional water resources. However, the possibilities of excessive 
SOUR WASTEWATERS

ORNL-DWG 82-15264

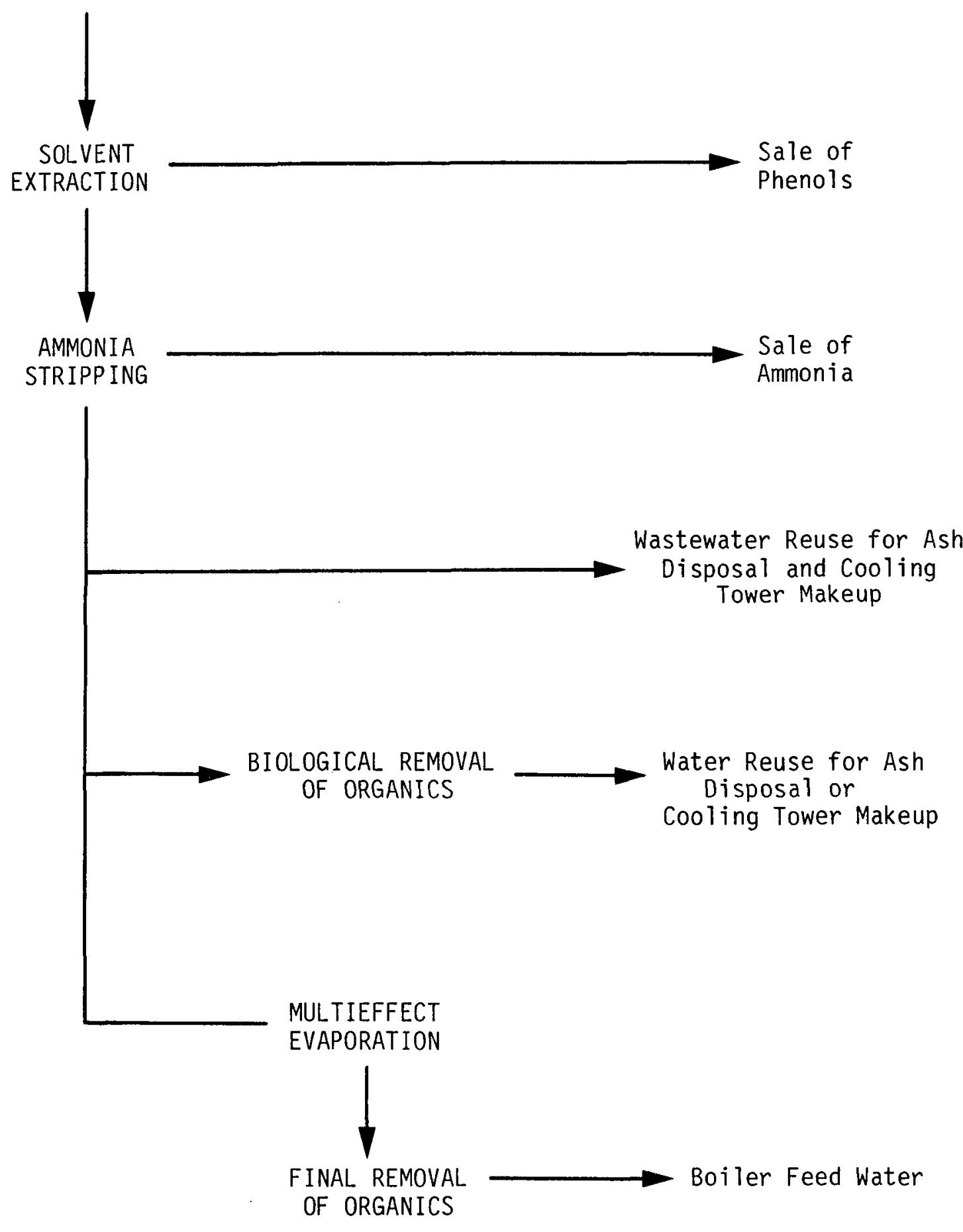

Fig. 7. Examples of wastewater reuse alternatives (Goldstein and Yang 1977). 
buildup of inorganic substances (e.g., chlorides) that may occur during water recycling should be examined especially in zero-effluent designs.

\subsubsection{Water Quality}

Potential water pollution problems associated with coal gasification and liquefaction result from three principal sources: (1) point-source effluents from waste treatment facilities; (2) surface runoff or leachate from solid waste disposal areas, coal stockpiles, or the other parts of the plant site; or (3) accidental spills that may occur during storage or transportation of liquid CDS. Consumptive water withdrawals may also reduce the dilution capabilities of local surface waters and thereby increase the impact of proposed or existing wastewater effluents. To evaluate the potential adverse effects on water quality, sufficient information should be developed to describe ambient, pre-project water quality conditions and to estimate post-project water quality conditions under various modes of operation. Even projects with zero-effluent designs under normal operation should consider the implications of wastewater discharges during abnormal operating periods (e.g., startup, shutdown, or equipment failure). Because these discharges are likely to contain the highest concentrations of hazardous or toxic wastes, the waste treatment procedures and chemical composition of all process condensates, sour waters, gas-stripping wastes, and cooling water blowdown should be described.

The specific pollutants formed during the production of CDS include a large number of inorganic, organic, and trace elements. A11 of the inorganic constituents of coal (Table 8) are potential constituents of the wastewaters discharged from CDS projects. In addition to these inorganic and trace elements, many complex organic molecules will be released by CDS projects. Several of these pollutants are among the 64 priority pollutants for which the U.S. Environmental Protection Agency has published water quality criteria (Table 10). For other potential effluent constituents, especially $\mathrm{PAH}$ compounds, there is little or no available information concerning 
Table 10. U.S. EPA water quality criteria for potential pollutants from coal gasification and liquefaction processes (all units are ug/L)

\begin{tabular}{|c|c|c|c|c|c|c|c|}
\hline & \multicolumn{4}{|c|}{$\begin{array}{l}\text { Criteria for } \\
\text { freshwater aquatic life }\end{array}$} & \multicolumn{2}{|c|}{$\begin{array}{r}\text { Toxicity to } \\
\text { freshwater aquatic life } \\
\end{array}$} & \multirow[t]{2}{*}{ Human health } \\
\hline & $24-h a$ & average & Not to & 0 exceed & Acute & Chronic & \\
\hline \multicolumn{8}{|l|}{ Trace elements } \\
\hline Arsenic & & -. & & 440 & -- & $\cdots$ & 0 \\
\hline Cadmium & $\exp [1.05]$ & $\ln (h)-8.53]$ & $\exp [1.05$ & $\ln (h)-3.73]$ & - & -- & 10 \\
\hline Chromium (hexavalent) & & 0.29 & & 21 & -- & - & 50 \\
\hline Chromium (trivalent) & & -- & $\exp [1.08$ & $\ln (h)+3.48]$ & -- & -- & 170,000 \\
\hline Copper & & 0.29 & $\exp [0.94$ & $\ln (h)-1.23]$ & -- & -- & $1000^{b}$ \\
\hline Lead & $\exp [2.35$ & $\ln (h)-9.48]$ & $\exp [1.22$ & $\ln (h)-0.47]$ & -- & -- & 50 \\
\hline Mercury & & 00057 & & 0.0017 & -- & -- & 0.000144 \\
\hline Nickel & $\exp [0.76]$ & $\ln (h)+1.06]$ & $\exp [0.76$ & $\ln (h)+4.02]$ & $\cdots$ & - & 13.4 \\
\hline Selenium & & 35 & & 260 & -- & -- & 10 \\
\hline Zinc & & 47 & $\exp [0.83$ & $\ln (h)+1.95]$ & -- & -- & $5000^{\mathrm{b}}$ \\
\hline \multicolumn{8}{|l|}{ Industrial wastes } \\
\hline Cyanide & & 35 & & 52 & -- & -- & 200 \\
\hline Phenol & & -- & & -- & 10,200 & 2,560 & $3500,300^{b}$ \\
\hline 2-4 dimethy lphenol & & - & & -- & 2,120 & -- & $400^{b}$ \\
\hline \multicolumn{8}{|l|}{ Aromatic hydrocarbons } \\
\hline PAH & & -- & & -- & -- & -- & 0 \\
\hline Naphthalene & & -- & & -- & 2,300 & 620 & Insufficient data \\
\hline Fluoranthene & & -- & & -- & 3,980 & -- & 42 \\
\hline Acenaphthene & & -- & & -- & 1,700 & 520 & $20^{b}$ \\
\hline
\end{tabular}

$\mathrm{a} h=$ water hardness measured as mg/ $\mathrm{L} \mathrm{CaCO}_{3}$.

B Based on taste and odor thresholds.

SOURCE: U.S. EPA 1980. 
environmental effects or acceptable concentrations in receiving waters. The analysis should identify all available. water quality standards (federal and state) for the individual waste constituents identified in project effluents.

The major nonpoint source of water pollution will occur as a result of surface runoff and leachate from coal CDS solids and ash storage and disposal areas (Wachter and Blackwood 1978). Plans should be discussed for covering stockpiles to minimize leachates and provisions for collection and/or treatment of surface runoff. Leachate test results for any solid waste generated by the project should be presented in discussing potential water quality degradation.

Prediction of the fate of pollutants as complex as those resulting from coal liquefaction or gasification is a difficult task requiring continued research. For example, PAHs released into aquatic environments undergo a combination of processes including dilution, dispersion, volatilization, photolysis, sorption, sedimentation, bioaccumulation, and metabolism by microorganisms (Herbes et al. 1980). These processes are controlled by both the characteristics of the aquatic environment and properties of the specific pollutant. To provide a basis for assessing risks to water quality, the environmental analysis should carefully describe properties of the receiving system, including:

- wind and water velocity patterns in the vicinity of effluent outfalls;

- other climatic factors such as temperature and sunlight regimes;

- morphology (e.g., depth and width) beginning at outfall locations and extending a reasonable distance downstream;

- descriptive hydrology of receiving water bodies; and ambient water quality, such as turbidity and suspended solids loads, that affect the fate of toxic pollutants. 
Accidental spills of liquid CDSs can also have adverse consequences in aquatic ecosystems. Because chemical and physical properties of petroleum crude $0 i 1$ and CDS liquids differ (e.g., higher phenolic, PAH, and nitrogen content and specific densities greater than 1.0), CDS spills will behave differently than petroleum spills (e.g., Appendix $Z$ in U.S. DOE 1981b). Data that should be included to assess the impacts of accidental spills are the following:

- likely transportation routes, transportation methods, and volumes of final CDS products to be shipped to various markets;

- chemical composition and physical properties of final products;

- proximity of transport routes to sensitive areas such as public water supply intakes, commercial and sport fisheries, or water-based recreation areas; and

- physical and hydrologic descriptions of receiving systems for potential CDS spills.

In most cases, one or two scenarios of spill events and locations will be adequate to assess the risks involved with accidental releases of CDS products into aquatic environments.

\subsubsection{Solid Waste Disposal}

Large volumes of solid waste will be generated during coal gasification and liquefaction processes. Between 20 and $40 \%$ of the coal feedstock in the conversion process will remain as solid wastes requiring disposal. These wastes will include:

- refuse from coal-cleaning operations;

- ashes, slag, and char remaining after the conversion processes;

- $\quad$ spent catalysts; and

- sludges produced in water and wastewater treatment and flue-gas desulfurization. 
Plans should be described for disposal of these wastes in an environmentally acceptable manner. The applicability of current federal or state regulations (e.g., Resource Recovery and Reclamation Act/hazardous waste regulations) concerning the disposal of solid wastes should be determined at the time of the project proposal by consultations with appropriate authorities, and the results of these consultations should be documented.

\subsubsection{Impacts on Biota}

Alterations in air and water quality and modifications in land-use patterns associated with the construction and operation of proposed CDS projects can result in major impacts on surrounding ecosystems. The primary impacts on terrestrial biota by industrial developments such as these are usually associated with loss of habitat. In addition to land-use changes which disturb natural habitats, atmospheric emissions can cause adverse effects on plant community productivity or species composition and thus result in indirect impacts on wildiife. The environmental analysis should discuss the sensitivity of local plant communities to acute and chronic stress that may be caused by atmospheric emissions. Other long-term phenomena such as deposition of trace elements and organics and their accumulation in soils and vegetation should also be assessed.

The increased human presence associated with accommodating a new workforce (Sect. 4.3.7) exacerbates the direct effects of the project on terrestrial biota. Indigenous species that are especially sensitive to disturbance (e.g., raptors) will be affected the most. Cumulative impacts leading to potential reductions in natural wildlife populations from such causes as habitat destruction, increased legal and illegal hunting pressure, and other sources of mortality (e.g., road kills or bird collisions with power lines) should be assessed.

Potential impacts on aquatic biota result from mechanisms similar to those acting on terrestrial biota. Wastewater effluents (Sect. 4.3.4) are a major concern, as are aquatic habitat loss and impingement or entrainment impacts associated with surface water 
withdrawals. Project effluents containing PAHs and other organic pollutants have a variety of adverse effects on aquatic biota, including acute and chronic toxicity, sublethal behavior modifications, bioconcentration, carcinogenicity, mutagenicity, and fish-flesh tainting (Braunstein et al. 1977b). All trophic levels can be affected, including algae which are as sensitive or more sensitive than higher organisms to the effects of many of the PAHs generated during CDS production (Giddings and Washington 1981).

The impacts of consumptive and nonconsumptive water withdrawals on aquatic biota can be significant, but are highly dependent on seasonality and cumulative effects of other water users. Worst-case scenarios during low-flow periods of the year should be used to examine any impacts on aquatic ecosystems, including habitat loss, water quality alterations, and entrainment/impingement of organisms. The seasonal requirements of sensitive life stages of affected aquatic species must also be recognized.

Using general background information on the existing environment, onsite habitat inventory data, and the project description, the environmental analysis should:

- describe impacts on terrestrial and aquatic biota, with special attention paid to endangered, threatened, rare, or otherwise protected plant and animal species;

- estimate the area of each type of habitat that will be disturbed during construction and operation;

- present a reclamation plan for all disturbed areas;

- evaluate the effects of the combined toxicity of individual waste constituents and, where applicable, combined waste effluents on species of affected plants and animals; and

- include results of consultations with state and federal fish and wildlife agencies and conservation personnel. 


\subsubsection{Socioeconomics}

Coal-derived synfuels (CDS) projects will be large-scale complexes involving not only the industrial facility and its transportation systems but also a variety of government and private institutions, workers, consumers, and other interested parties. A wide range of possible social and economic impacts, which in turn may influence development decisions, will occur within this network of project elements. It is particularly difficult to generalize about the probable critical impacts because the nature of the delivery system will vary with the technology and the site. However, factors related to population growth and water availability will clearly be of concern for most projects.

Potential benefits accruing from CDS developments include increased employment, broader tax base, community improvements in a range of available services and facilities, and the stimulation of secondary businesses. These benefits, however, must be balanced against potential impacts such as housing shortages, strains on public services and utilities, symptoms of social stress, small business failures, water shortages, solid waste disposal problems, and perceived decrease in "quality of life" by some residents.

For large-scale CDS projects where significant impacts are anticipated, baseline data needs should provide the following kinds of information:

- population size and composition (ethnic, age, sex, education, and urban/rural mix);

- population change rates (migration, fertility, and mortality);

- locar governmental characteristics (jurisdiction, intergovernmental unit coordination and revenue mechanisms, tax and bonding structures, planning and zoning capabilities, political systems);

- economic structure (businesses, financial institutions and resources, trade); 
- labor force characteristics (number and type of jobs, income levels, unions);

- public services (water, sewer, police, fire, health, education, transportation, welfare, parks, churches);

- housing stock;

- local organizations and interest groups (supporters and opponents of the proposed project and energy developments in general);

- social structure and life-styles (orientations, salient concerns, attitude to newcomers);

- quality of life features (cost of living, marriage and divorce rates, crime rates, recreation access, transportation);

- institutional, economic, and legal aspects of water supply issues for the facility; and

- institutional, economic, legar, and social issues involved in facility siting and solid waste disposal.

Projections from these data, both with and without development (including alternatives under consideration), can be used to identify potential impacts. The coal conversion facility itself will demand certain services in addition to those required by additional residents. Demands on utilities, including transportation, water, and power, may compete with other users.

The types of potential impacts to be considered are:

- rapid population growth and subsequent decline over the life of the project (construction, operation, and decommissionings);

- project-induced housing shortages;

- public service shortfalls (including transportation impacts);

- temporal and jurisdictional dissociations of costs and benefits for local governments; 
- institutional, economic, and social effects of competition for the local water supply;

- institutional, economic, and social effects of land-use changes and solid waste disposal needs;

- significant changes in political, economic, and social structures, with special consideration of their effects on the life-styles of residents;

- community disruption or project delays from local opposition and support to the proposed project; and

- project-induced special needs such as occupational health problems, demand for psychological counseling, etc.

The analysis of impacts should also consider the possibility of secondary developments as well (e.g., sulfur processing and supplier industries). Long-term effects should be contrasted with immediate impacts. Possible concerns to be considered include long-term constraints on local and regional development as the coal conversion facility competes for water, contributes to air quality degradation, etc.

Given current uncertainties, attention should be paid to the institutional, legal, and economic aspects of health problems posed by the proposed coal gasification or liquefaction facilities (Sect. 4.3.8). Popular and institutional perceptions of risks to workers and to neighbors should be considered along with possible mitigation strategies. Controversy could develop over such perceptions of health risks as well as other issues of environmental degradation. Federal and state regulatory requirements and potential legal issues (e.g., water availability or surface mining rights) should be noted. Local attitudes toward all issues should be obtained directly whenever possible. The development of communication channels between resident groups, developers, and governmental bodies is highly desirable.

Significant degradation of existing aesthetic, historic, cultural, and archaeological resources could result from project-related mining, construction, air and water degradation, road traffic, coal 
transportation, and secondary development. Effects of odor and noise on residents should be noted. Visual concerns should be addressed in light of terrain and local sensitivity with consideration of such features as cooling towers, new power lines, reclamation plans, and secondary commercial and population growth activities.

Finally, special emphasis should be placed on identifying the amount and sources of funds available for mitigation of potential adverse impacts.

\subsubsection{Health and Safety}

Production of carcinogens and mutagens are of special concern during coal liquefaction and gasification. Biologically active agents are usually associated with the potential emission of hydrocarbons, particularly the polycyclic aromatic hydrocarbons (PAHs) and polycyclic aromatic amines (PAAs). The accumulated evidence supports the possibility of a strong association between worker exposure to high concentrations of coal carbonization products and risk of cancer. However, establishment of dose-response or exposure-response relationships based on exposure to one or a few constituents of coal carbonization is extremely difficult. Although PAHs with known carcinogenic properties [e.g., benzo(a)pyrene] have been measured in coal carbonization products, the production of CDS includes highly complex mixtures of hundreds of hazardous organic compounds and inorganic materials (e.g., sulfur compounds, trace metals and their compounds, and radioactive materials - in short, anything in coal plus any compounds produced in the conversion process). While numerous potential carcinogens have been identified in coal conversion process streams, effluents, and products (Attari 1973; Fourney et al. 1974; Braunstein et a1. 1977a,b), current toxicological, epidemiological, and theoretical information is insufficient for precise extrapolation to human health impacts.

Potential risks to the general public associated with synthetic fuels must await further research before they can be assessed. Possible emissions from coal conversion processes include particulates, 
carbon monoxide, hydrocarbons, nitrogen sulfur compounds, and trace elements. Final product use will be one exposure determinant. For example, although levels of carcinogens may be high in syncrudes, the potential chemical reactions between these materials during distillation or refinement is unknown. It is possible that carcinogens may be reduced in quantity as crude materials are refined.

In preparing an environmental analysis, the following health and safety issues should be considered and addressed as appropriate to the types of processes being proposed:

- exposure to PAHs and other potential carcinogens and mutagens released during the gasification and liquefaction processes;

- exposure to potentially toxic materials emitted during coal cleaning processes, including organic solvents used to clean coal (U.S. DOE 1979);

- acute effects such as inhalation, severe respiratory irritation, and chemical and thermal burns in workers exposed to fugitive emissions, leaks, and spills;

- potential fire and explosion risks associated with the production and handling of flammable materials at high temperatures and pressures (Harris et al. 1980);

- exposure to synthetic crude products which have been found to be more carcinogenic than natural crudes (Epler 1978; Holland et a1. 1978) and which contain polycyclic aromatic amines (PAAs) that exhibit exceptionally high mutagenicities (Guerin et a1. 1980); and

- exposure to high noise levels associated with coal preparation and other plant operations.

A series of new regulations are emerging under the Clean Air Act, Water Pollution Control Act, Resource Conservation and Recovery Act, Toxic Substances Control Act, and OSHA criteria documents. Adequate control technologies and workplace monitoring will need to be deployed to reduce emissions and wastes to a level sufficient to protect the health and safety of workers and the public as outlined in these evolving regulations (U.S. DOE 1978a,b). 
The design and implementation of industrial hygiene and safety programs will be necessary to reduce worker exposures to a variety of mutagenic and carcinogenic materials as well as trace metals. These programs should include medical surveillance of workers, training in personal hygiene, and decontamination procedures (U.S. DOE 1978a,b). 


\subsection{REFERENCES}

Acurex Corporation. 1977. Preliminary environmental assessment of combustion modification techniques. Volume II, Technical results. PB-276-681. Prepared for U.S. Department of Commerce, Washington, D.C.

Attari, A. 1973. The fate of trace constituents of coal during gasification. EPA-650/2-73-004. U.S. Environmental Protection Agency, Washington, D.C.

Bechtel National, Inc. 1979. Compilation and assessment of SRC experience: Data book. AF-1019. Electric Power Research Institute, Palo Alto, California.

C. F. Braun \& Co. 1979. Coal-to-methanol via new processes under development: An engineering and economic evaluation. AF-1227. Electric Power Research Institute, Palo Alto, California.

Braunstein, H. M., E. D. Copenhaver, and H. A. Pfuderer (eds.). 1977a. Environmental, health, and control aspects of coal conversion: An information overview. ORNL/EIS-94, Vol. I. Oak Ridge National Laboratory, Oak Ridge, Tennessee.

Braunstein, H. M., E. D. Copenhaver, and H. A. Pfuderer (eds.). 1977b. Environmental, health, and control aspects of coal conversion: An information overview. ORNL/EIS-95, Vol. II. Oak Ridge National Laboratory, Oak Ridge, Tennessee.

Eccles, R. M., and G. R. DeVaux. 1981. Current status of H-Coal commercialization. Section 7. IN Conference Proceedings: Synthetic Fuels - Status and Directions. WS-79-238, Volume 1. Electric Power Research Institute, Palo Alto, California.

Epler, J. L. 1978. Integrated chemical and biological testing of synthetic oils and effluents. pp. 128-136. IN Symposium on Potential Health and Environmental Effects of Synthetic Fossil Fuel Technologies. CONF-780903. Technical Information Center, Oak Ridge, Tennessee.

Epperly, W. R., K. W. Plumlee, and D. T. Wade. 1981. Exxon donor solvent coal liquefaction process: Development program status III. Section 6. IN Conference Proceedings: Synthetic Fuels Status and Directions. WS-79-238, Volume 1. Electric Power Research Institute, Palo Alto, California. 
Fourney, A. J., W. P. Haynes, S. J. Gasior, G. E. Johnson, and J. P. Strakey, Jr. 1974. Analys is of tars, chars, gases, and water found in effluents from the synthane process. IN Symposium Proceedings: Environmental Aspects of Fuel Conversion Technology. EPA-650/2-74-118. U.S. Environmental Protection Agency, Washington, D.C.

Fuessle, R. W., R. M. Lyon, E. D. Brill, Jr., G. E. Stout, and K. E. Wojnarowski. 1978. Power development and water allocation in Ohio River Basin. J. Water Resour. Plan. Manage. Div., ASCE 104 (WR I) : 193-209.

Gehrs, C. W. 1977. Environmental implications of coal conversion technologies: Organic contaminants. pp. 157-175. IN J. H. Thorp and J. W. Gibbons (eds.), Energy and Environmental Stress in Aquatic Systems. CONF-771114. Technical Information Center, Oak Ridge, Tennessee.

Giddings, J. M., and J. N. Washington. 1981. Coal liquefaction products, shale 0il, and petroleum: Acute toxicity to freshwater algae. Environ. Sci. Techno1. 15:106-108.

Goldstein, D. J., and D. Yang. 1977. Water conservation and pollution control in coal conversion processes. EPA/600/13. U.S. Environmental Protection Agency, Research Triangle Park, North Carolina.

Guerin, M. R., C. H. Ho, T. K. Rao, B. R. Clark, and J. L. Epler. 1980. Polycyclic aromatic primary amines as determinant chemical mutagens in petroleum substitutes. Environ. Res. 23:42-53.

Harris, L. L., J. A. Gideon, S. Berardinel1i, L. D. Reed, R. D. Dobbin, J. M. Evans, D. R. Telesca, and R. K. Tanita. 1980. Coal liquefaction: Recent findings in occupational safety and health. Special Technical Report. U.S. Department of Health and Human Services, National Institute for Occupational Safety and Health, Rockville, Maryland.

Herbes, S. E., G. R. Southworth, D. L. Shaeffer, W. H. Griest, and M. P. Maskarinee. 1980. Critical pathways of polycyclic aromatic hydrocarbons in aquatic environments. pp. 113-128. IN H. Witschi (ed.), The Scientific Basis of Toxicity Assessment. Elsevier/North Holland Biomedical Press, New York.

Holland, J. M., M. S. Whitaker, and J. W. Wesley. 1978. Carcinogenicity of syncrude relative to natural petroleum as assessed by repetitive mouse skin application. pp. 137-142. IN Symposium on Potential Health and Environmental Effects of Synthetic Fossil Fuel Technologies. CONF-780903. Technical Information Center, Oak Ridge, Tennessee. 
MITRE Corporation. 1981a. Environmental effects of coal technologies: Research needs. Report to the Federal Interagency Committee on the Health and Environmental Effects of Energy Technologies. MTR-79W159-03. McLean, Virginia.

MITRE Corporation. 1981b. Health and environmental effects of synthetic fuel technologies: Research priorities. Report to the Federal Interagency Committee on the Health and Environmental Effects of Energy Technologies. MTR-80W348. McLean, Virginia.

Mol1, N. G., V. T. May, G. J. Quarderer, and G. A. Stuart. 1981. Dow coal liquefaction process update. Section 14. IN Conference Proceedings: Synthetic Fuels - Status and Directions. WS-79-238, Volume 1. Electric Power Research Institute, Palo Alto, California.

Murin, P., T. Sipes, and G. C. Page. 1980. Environmental assessment report: Wellman-Galusha low-Btu gasification systems. EPA-600/7-80-093. U.S. Environmental Protection Agency, Industrial Environmental Research Laboratory, Research Triangle Park, North Carolina.

National Academy of Sciences (NAS). 1977. Assessment of technology for the liquefaction of coal. FE/1216-3. U. S. Government Printing office, Washington, D.C. $153 \mathrm{pp}$.

Parker, N. A., and B. L. Thompson. 1976. U.S. coal resources and reserves. Fed. Energy Admin. Bul1. FEA/B-76/210. National Energy Information Center, Washington, D.C.

PEDCO Environmental Specialists, Inc. 1976. Evaluation of fugitive dust emissions from mining. Task 1 Report, Identification of Fugitive Dust Sources Associated with Mining. Cincinnati, Ohio.

Rogers, K. A., A. S. Wilk, B. C. McBeath, and R. F. Hill. 1978. Comparison of coal liquefaction processes. FE-2468-25. U.S. Department of Energy, Washington, D.C.

Ruch, R. R., H. J. Gluskoter, and N. F. Shimp. 1974. Occurrence and distribution of potentially volatile trace elements in coal: A final report. Environ: Geol. Notes No. 72. Illinois State Geological Survey, Urbana, Illinois.

Salmon, R., M. S. Edwards, and R. M. Wham. 1980. Production of methanol and methanol-related fuels from coal. ORNL-5564. 0ak Ridge National Laboratory, Oak Ridge, Tennessee. 97 pp.

Strakey, J. P., A. J. Forney, and W. P. Haynes. 1975. Methanation in coal gasification processes. PERC/IC-75/1. Pittsburgh Energy Research Center. Pittsburgh, Pennsylvania. 
Sullivan, R. F., D. J. O'Rear, B. E. Strangeland, and H. A. Frumkin. 1981. Cost comparisons of alternative routes for converting SRC-IIoil-to-distillate fuels. Section 9. IN Conference Proceedings: Synthetic Fuels - Status and Directions. WS-79-238, Volume 1. Electric Power Research Institute, Palo Alto, California.

U.S. Department of Energy (U.S. DOE). 1978a. Environmental readiness document - Coal gasification. DOE/ERD-0012. National Technical Information Service, Springfield, Virginia.

1978b. Environmental readiness document - Coal Tiquefaction. DOE/ERD-0015. National Technical Information Service, Springfield, Virginia.

1979. Environmental readiness document - Coal extraction and preparation technology. DOE/ERD-0024. National Technical Information Service, Springfield, Virginia.

1981b. Final Environmental Impact Statement Solvent Refined Coal-I Demonstration Project.

1981c. Final Environmental Impact Statement. Memphis Light, Gas and Water Division, Industrial Fuel Gas Demonstration Project. DOE/EIS-0071. Washington, D.C.

1981d. Final Environmental Impact Statement (2 volumes). Solvent Refined Coal-II Demonstration Project. DOE/EIS-0069/VI and DOE/EIS-0069/V2. Washington, D.C.

U.S. Environmental Protection Agency (U.S. EPA). 1973. Compilation of Air Pollutant Emission Factors, Second Edition and Supplements. AP-42. Washington, D.C.

1978a. Inventory of Combustion-Related Emissions from Stationary Sources (Second Update). EPA-600/7-78-100. Washington, D.C.

1978b. Pollutant Emissions from "Dirty" Low- and Medium-Btu Gases. EPA-600/7-78-191. Washington, D.C.

1980. Water quality criteria documents: Availability. Fed. Regist. 45(231): 79318-79379.

U.S. General Accounting office (U.S. GAO). 1977. U.S. coal development -- promises, uncertainties. EMD-77-43. U.S. Government Printing office, Washington, D.C. 
Wachter, R. A., and T. R. Blackwood. 1978. Source assessment: Water pollutants from coal storage areas. EPA-600/2-78-004m. U.S. Environmental Protection Agency, Cinncinati, Ohio.

Wham, R. M., J. F. Fisher, R. C. Forrester III, A. R. Irvine, R. Salmon, S. P. N. Singh, and W. C. Ulrich. 1981. Liquefaction technology assessment - phase I: Indirect liquefaction of coal to methanol and gasoline using available technology. ORNL-5664. Oak Ridge National Laboratory, 0ak Ridge, Tennessee. 398 pp.

Whitlach, E. E., Jr. 1977. Coal gasification and water resources development. J. Water Res. Plan. Manage. Div., ASCE 103(WR2):299-314. 
$9 k$

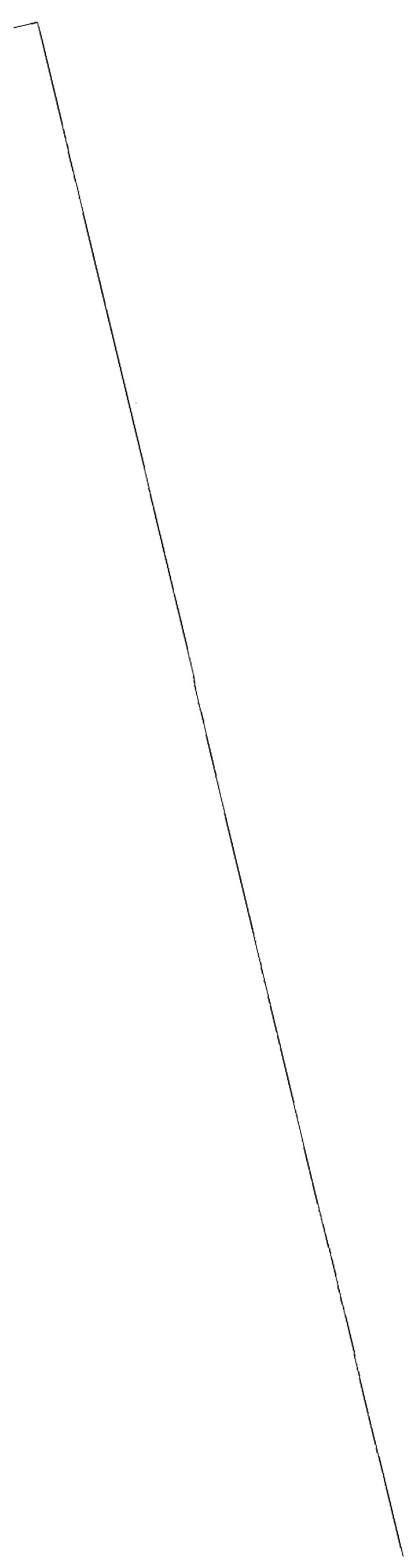

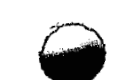




\section{PEAT}

Robert M. Reed, 1 Larry D. Voorhees, 1 P. J. Mulholland, 1
and Martin Schweitzer

\subsection{RESOURCE DESCRIPTION}

Peatlands are wetland ecosystems in which more organic matter is produced than is decomposed, resulting in the formation of an organic deposit. A lack of free oxygen, usually associated with a water-saturated substrate or standing water, slows organic matter decomposition. Most peatlands have formed over the past 10,000 to 12,000 years, with many being only 2000 to 5000 years $01 d$. The composition of peat deposits is rarely homogeneous and usually varies with depth, reflecting past changes in climate and vegetation. Important factors contributing to the development of a particular peatland are climate, topography, drainage, sources of nutrients, vegetation, and history of development and disturbance. These factors need to be evaluated and understood in predicting environmental impacts resulting from harvesting peatlands.

The size of the world peat resource is poorly known at the present timing especially in tropical regions. Published estimates have ranged from $165 \times 10^{6}$ to $421 \times 10^{6}$ ha (U.S. DOE 1979a, Kivinen and Pakarinen 1980). Table 11 shows that the nations having the largest areal extent of peatlands are Canada, the Soviet Union, and the United States, while resources in at least 11 other countries exceed $1 \times 10^{6}$ ha. Data on peat resources in developing countries (e.g., Burundi, Sri Lanka, and Brazil) are just beginning to be collected. Such information will undoubtedly increase estimates of the size of the world's peat resource significantly.

Characteristics of potentially exploitable peat deposits differ by geographic location and history of development. Peat forms in one of

\footnotetext{
'Environmental Sciences Division, ORNL. ${ }^{2}$ Energy Division, ORNL.
} 
Table 11. World peat resource estimatesa

\begin{tabular}{lc}
\hline Region & $\begin{array}{c}\text { Area } \\
\left(10^{6} \mathrm{ha}\right)\end{array}$ \\
\hline EUROPE & 28.2 \\
Finland & 10.4 \\
Sweden & 7.0 \\
Norway & 3.0 \\
United Kingdom of Great Britain & \\
and N. Ireland & 1.6 \\
Poland & 1.4 \\
Republic of Ireland & 1.2 \\
West Germany & 1.1 \\
Iceland & 1.0 \\
Others & 1.5 \\
& 182.1 \\
ASIA $\quad 150$ \\
USSR & 26 \\
Indonesia & 3.5 \\
China & 2.4 \\
Malaysia & 0.2 \\
Japan & 210.2 \\
NORTH AMERICA & 170 \\
Canada & $40.2(61.0)^{\mathrm{b}}$ \\
United States & 0.60 \\
OTHERS & 421.1 \\
TOTAL & \\
\hline
\end{tabular}

akivinen and Pakarinen 1980.

bFarnham 1980. 
two general ways: (1) by lake-filling processes in which organic materials accumulate in shallow, poorly drained basins (e.g, former ponds, lakebeds, or poorly drained terraces), and (2) by paludification (i.e., swamping) in which sphagnum mosses and associated wetland plants gradually invade flat to moderately sloping mineral soils modifying existing drainage patterns thereby creating waterlogged conditions. Depths of deposits can vary from a few centimeters to more than $6 \mathrm{~m}$.

Although peat deposits are found in the western states (Cameron 1980), proposals for using peat for energy have primarily been restricted to the north-central, northeastern, and southeastern regions of the United States. In the northern Midwest and New England, peat deposits have formed on poorly drained landscapes left by receding glaciers. A variety of peatland types occur in these areas, including (1) raised bog deposits in Maine; (2) numerous small, deep basin deposits in Wisconsin, New York, and New England (Cameron 1980); and (3) extensive complex patterns of raised peatlands in Minnesota (Heinselman 1970). On the southeastern coastal plain, extensive peat deposits formed in large swamps and marshes as sea levels rose and fell during the past 10,000 years (Whitehead 1972, Heath 1975). In North Carolina, for example, three major types of peatlands have been distinguished (Otte and Ingram 1980): (1) pocosins (i.e., evergreen shrub bogs on the southeastern coastal plain) occurring in extensive shallow depressions (e.g., the Dismal Swamp and the Pamlimarle Peninsula), (2) floodplain peats along major rivers draining the coastal plain, and (3) elliptical-shaped Carolina Bays of unknown origins.

Peatlands have been considered a potential energy resource for many years, but only recently has any serious consideration been given to developing U.S. peat deposits for this purpose. Estimates of the energy availability in proven reserves of peat in the United States are tentative, but Farnham (1978) made a preliminary estimate that these reserves may contain as much as 1524 EJ (1443 quads). Recent surveys in some states (e.g., North Carolina) found much less peat than 
predicted by Farnham (Otte and Ingram 1980), while surveys in other states (e.g., Alaska) found much more (Farnham 1980).

Peat deposits are present in 42 states (Cameron 1980). A recent evaluation of the peat resource in the United States found that Alaska has the largest extent of peatlands, with approximately $51 \times 10^{6}$ ha, of which only $2.2 \times 10^{6}$ ha are believed to be fuel-grade quality (Farnham 1980). The total U.S. resource is estimated to be approximately $61 \times 10^{6}$ ha (Table 12). Figure 8 shows the distribution of major peatland regions in the 48 conterminous states. Fifty-seven percent of the resource is in the north-central states of Minnesota, Michigan, and Wisconsin; $24 \%$ is on the southeastern coastal plain (North Carolina, Florida, and Louisiana); and the remaining $20 \%$ is scattered throughout the remainder of the Southeast, New England, the Rocky Mountain States, and the West Coast.

Although the general distribution of the U.S. resource is fairly well known, many peat deposits do not contain fuel-grade peat or are

Table 12. United States peat resources

\begin{tabular}{|c|c|c|}
\hline & $\begin{array}{l}\text { Hectares } \\
\times 10^{6}\end{array}$ & $\begin{array}{l}\text { Percent of total } \\
\text { (excluding Alaska) }\end{array}$ \\
\hline $\begin{array}{l}\text { Alaska } \\
\text { Minnesota } \\
\text { Michigan } \\
\text { Florida } \\
\text { Wisconsin } \\
\text { Louisiana } \\
\text { North Carolina } \\
\text { Maine } \\
\text { New York } \\
\text { Others }\end{array}$ & $\begin{array}{l}50.59 \\
2.91(2.4)^{b} \\
1.83 \\
1.21 \\
1.15 \\
0.73 \\
0.49(0.24)^{c} \\
0.31 \\
0.26 \\
1.49\end{array}$ & $\begin{array}{r}28.0 \\
17.6 \\
11.7 \\
11.1 \\
7.0 \\
4.7 \\
3.0 \\
2.5 \\
14.4\end{array}$ \\
\hline Total & 60.97 & 100.0 \\
\hline
\end{tabular}




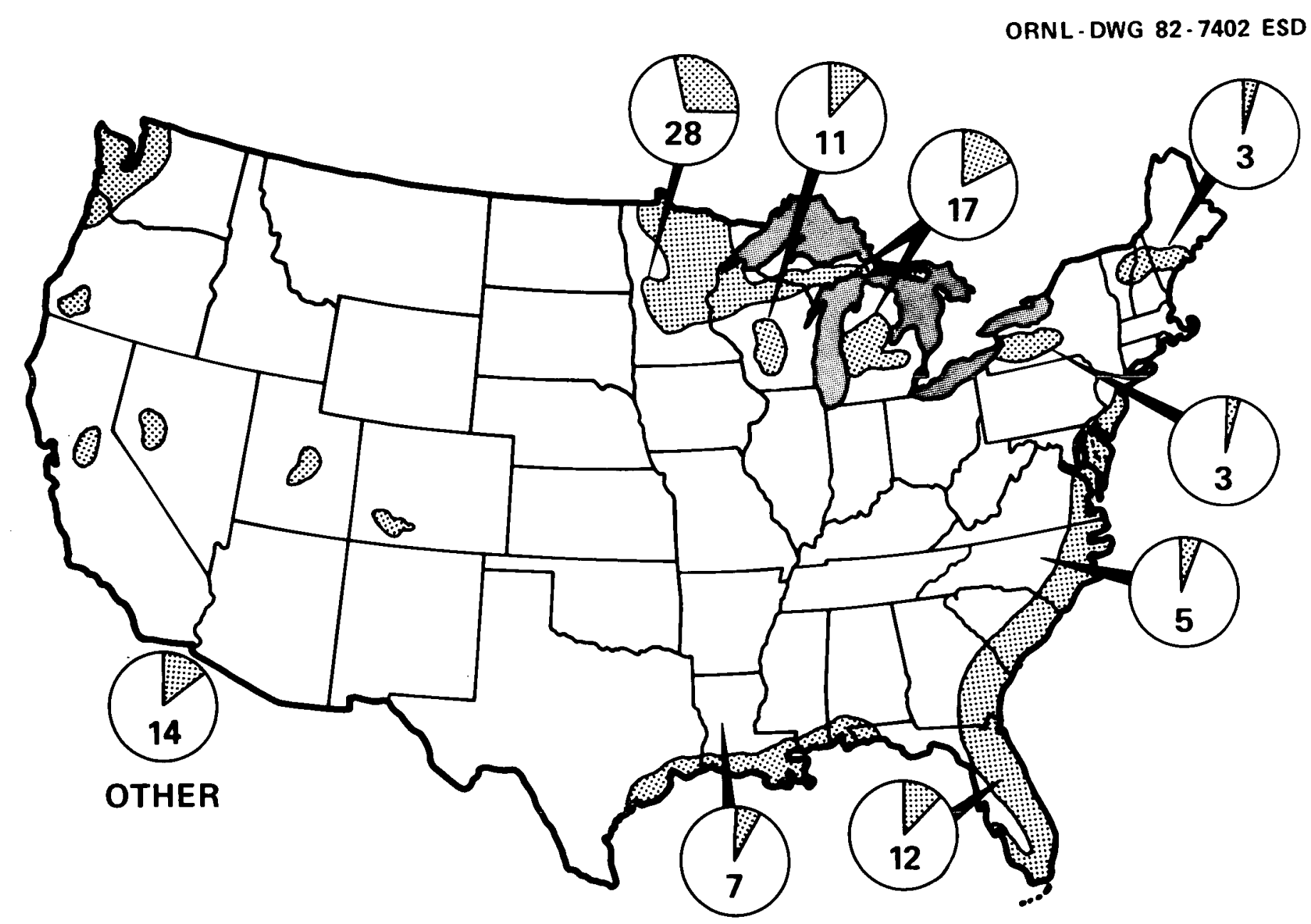

Fig. 8. Distribution of peat resources in the United States, excluding Alaska and Hawaii. Numbers indicate the proportion (\%) of the resource in the 48 contiguous states that is present in individual states. Adapted from U.S. DOE (1979). 
too widely scattered to be economically recoverable. In a number of states, the U.S. Department of Energy has been sponsoring detailed inventories of peat resources. The data from these efforts, however, will not be available for several years (Mayer and Christianson 1982).

\subsection{TECHNOLOGY OVERVIEW}

A major restriction to development of peat for energy is the high economic cost associated with transporting the unprocessed peat. Peat has a low energy content compared to coal and has a high moisture content (often in excess of $90 \%$ ) before it is dewatered. Peat projects will, therefore, normally be located close to peat deposits and will combine mining, dewatering, and energy conversion operations to reduce transportation costs. An exception is the First Colony Farms, Inc., operation in North Carolina that is primarily oriented toward harvesting the peat for sale as a horticultural supplement or as a fuel and using the mined peatlands for agriculture. However, even in this case, proposed energy conversion facilities will be located near the harvest site (Edelman and Manfred 1982, Rea 1982).

The following discussion of peat energy technology addresses four basic steps in the peat fuel cycle: (1) peatland preparation, (2) harvesting (mining), (3) dewatering, and (4) energy use or conversion. Alternative approaches for each step are considered.

\subsubsection{Peatland Preparation}

The type of peatland preparation required for a particular project depends on whether a wet or dry harvest method is used. With dry harvest methods, a drainage system is established, surface vegetation and obstructions (e.g., rocks or stumps) are removed, the peat land surface is sloped toward the ditches to promote surface drainage, and access roads for machinery are constructed. The spacing and pattern of ditches depends on factors such as the type of harvest equipment to be used, the difficulties of establishing adequate drainage flow, and the system for transporting peat to the site of use. Preparing for harvest normally requires two to five years (Allen 1982, Campbell 1981, 
Tomiczek et a1. 1982). Wet harvest methods require removal of trees and brush and management of water levels to permit the use of floating barges for dredging operations. Dikes may be required to ensure that adequate water levels are maintained.

\subsubsection{Harvesting}

Dry harvest methods produce milled or sod peat, while wet harvest methods produce a peat-water slurry or bulk wet peat. The method of harvest depends on: (1) the amount of peat required, (2) climatic conditions (e.g., length of harvest and drying seasons), (3) peatland location and physical characteristics (e.g., ease of access and feasibility of implementing drainage), and (4) need for a continuous supply of peat and the problems associated with stockpiling.

\subsubsection{Milled Peat}

The milled peat harvest method is widely used in the Soviet Union and Europe and to a limited extent in the United States and Canada. Special machinery removes a thin layer of peat $(0.6$ to $5.0 \mathrm{~cm})$ from the peatland surface. This loose material is turned one to several times to promote drying and is then windrowed or is collected with large vacuum harvesters for eventual transport to stockpiles. By turning the milled peat every half hour under favorable conditions, a $30 \%$ moisture content can be obtained in 2 to $3 \mathrm{~h}$ (Allen 1982, Campbell 1981). In North Carolina, the First Colony Farms, Inc., has had to modify machinery and procedures to handle the large quantities of buried wood that is present in their deposits.

\subsubsection{Sod Peat}

Sod peat is removed with a cutting machine that extrudes a sod approximately $10 \mathrm{~cm}$ in diameter and 20 to $30 \mathrm{~cm}$ long. These sods are spread on the field to dry and then windrowed for further drying and removal to stockpiles. First Colony Farms has found that sod peats can be dried to $30 \%$ moisture content within 7 to $12 \mathrm{~d}$ (Allen 1982). 


\subsubsection{Wet Peat}

A wet harvest method is generally used if (1) the bog will not support heavy machinery, (2) climatic conditions are unfavorable for dry harvest, or (3) the terrain is unsuitable for drainage. Wet harvest methods generally use water to form a peat-water slurry for transporting peat to the conversion site. Harvest techniques include: (1) washing peat from the sides of exposed ditches with high pressure streams of water, followed by pumping the peat-water slurry in the ditches to the conversion site or (2) using floating dredges or draglines to excavate the peat, followed by mixing and screening the excavated material to form a slurry for pumping to the site. An important difference between wet and dry harvest methods is that wet harvesting is a one-pass operation that excavates all the harvestable peat from one part of the peatland before moving on to the next part. In contrast, dry harvest operations remove a thin layer of peat from the entire peatland surface at each pass, continuing until the harvestable area is mined out, usually involving several to many years.

\subsubsection{Dewatering}

Because peat harvested by either wet or dry methods has a high moisture content (often exceeding 90\%), dewatering to a moisture content of $50 \%$ or less is required. To obtain $50 \%$ moisture peat from $90 \%$ moisture peat, $8 \mathrm{~kg}$ of water must be removed from each $\mathrm{kg}$ of dry peat (dry weight basis)(Tsaros 1982).

If dry harvest methods are used, the sod or milled peat is spread over the peatland surface to dry in the sun (Lindstrom 1980, Campbe11 1981, Mundale 1981). Field drying can produce peat having moisture contents from 30 to $55 \%$ but is 1 imited by favorable weather and by the amount of land surface needed to dry the peat. For example, if milled peat were to be used for a $264 \times 10^{12} \mathrm{~J} / \mathrm{d}$ substitute natural gas (SNG) facility, more than 52,000 ha of peatland would be dedicated to peat harvesting to provide the $52 \times 10^{9} \mathrm{~kg}$ of $50 \%$ moisture peat needed per day (Tsaros 1982). 
For wet harvest operations, alternative approaches for dewatering the peat-water slurry include: (1) mechanical dewatering; (2) solvent extraction; (3) wet carbonization; and (4) partial wet oxidation. Mechanical dewatering uses a press similar to that used for dewatering sludges or paper pulp. By combining mechanical dewatering to reduce the moisture content to $70 \%$ with thermal drying (often using process or waste heat), $50 \%$ moisture peat can be produced.

Solvent extraction dewatering involves mixing wet peat with an organic solvent. The solubility of water in the peat is increased by subjecting the mixture to elevated temperatures and pressures. Most of the water in the peat dissolves in the solvent, and the solids and liquids can then be separated. Laboratory experiments by the Institute of Gas Technology, using a variety of solvents, showed that as much as $90 \%$ of the water in the peat could be removed with this technique using benzene as a solvent (Paganessi et al. 1980).

Wet carbonization is a beneficiation process that heats the wet peat under pressure (e.g., $3.4 \times 10^{6} \mathrm{~Pa} \cdot \mathrm{s}$ at $204^{\circ} \mathrm{C}$ ). The colloidal structure of the peat is broken down in the process, allowing the product to be mechanically dewatered to a moisture content of $35 \%$ (Tsaros 1982). Partial wet oxidation is similar to wet carbonization with the exception that the heat needed for the reaction is generated by partialiy combusting the peat within a reactor, thus using some of the energy content of the potential product.

The dewatering process may be bypassed if complete oxidation processes, which burn as much as $98 \%$ of the Slurry organic matter, are used to produce heat and steam. In addition, biogasification uses a wet peat-water slurry directly in fermentation to produce methane, thereby bypassing the dewatering phase (Ghosh and Klass 1979, Smith 1981).

\subsubsection{Use or Conversion}

Peat can be used directly as a boiler fuel or indirectly as a feedstock for gasification or liquefaction facilities. Direct combustion to produce steam for electricity generation or heating is a 
proven technology in Europe and the Soviet Union. Peat gasification and liquefaction technologies are under development in the Soviet Union, Scandinavia, and the United States. The size of direct combustion facilities can vary from small plants designed to provide a restricted supply of electricity and/or heat for a local industry or community to a large power or heating plant that can significantly contribute to regional energy demands. Gasification and liquefaction plants will most likely be large facilities, [e.g., one that was proposed for the Minnesota Gas Company would have produced SNG equivalent to $260 \times 10^{12} \mathrm{~J} / \mathrm{d}$ (Punwani et a1. 1977)].

\subsubsection{Direct combustion}

Hand-cut peat has been used for domestic heating and cooking for thousands of years. The technology for using peat as a boiler fuel to produce electricity and heat was first developed in the Soviet Union in 1922. Currently the USSR has over 70 peat-fired power plants, the largest of which is rated at 723 MWe (Punwani 1982). Since 1950, ten peat-fired power stations, ranging in size from 20 to 40 MWe, have been built in Ireland and currently provide approximately $16 \%$ of that nation's electricity (Brophy 1982). Finland has a rapidly expanding peat energy program with 19 electrical power stations and district heating plants in operation.

Peat-fired power and district heating plants are similar to coal-fired facilities in most respects. The facilities are typically located near the source of fuel because transporting peat long distances is uneconomical. Peat stockpiles are usually located on or immediately adjacent to the peat fields except for relatively small ready reserve piles at the combustion site. Transportation of the peat to the facility may be by narrow-guage railroad, truck, conveyer, or slurry pipeline depending on the distance and the type of harvesting and dewatering operation.

Field-dried peat fuel can have a highly variable moisture content, especially if the peat comes from several sources. Irish experience has found that by blending peats from different sources the moisture 
content of the fuel can be controlled within two percentage points of the average, thereby stabilizing combustion conditions (Brophy 1982).

Residues of combustion include boiler and fly ash which may be used as a soil supplement in peatland reclamation or may require landfill disposal. The high lime ash produced in Irish peat-burning facilities clogs ash handling equipment, and special techniques are needed to move it from the combustion facility to disposal ponds (Brophy 1982). Dry ash is very finely divided (i.e., powder) and is difficult to handle.

Dried peat is a highly reactive fuel, with low bulk density, high volatility, high oxygen and nitrogen, and low sulfur and ash content (Table 13). The high nitrogen content may cause air pollution problems (King et al. 1980).

\subsubsection{Thermal gasification}

Peat gasification technologies are generally similar to those being developed for coal. A discussion of the basic technology for gasification processes is presented in sect. 4.2.1 of this report. Peat provides an excellent feedstock for conversion to substitute natural gas (SNG), because it tends to form more hydrocarbon gases than lignite and subbituminous coals (Punwani et al. 1980).

One approach for producing $S N G$ is to use a single-stage peat gasifier with a fluidized bed or an entrained bed. A synthesis gas is produced by gasifying the peat with steam and oxygen and then processing the gas to produce SNG. Although this approach is limited to producing a single product (i.e., SNG) and produces large amounts of tars, it has the major advantage of using commercially available fluidized and entrained bed equipment (Kopstein 1982).

An alternative approach to single-stage gasification is the two-stage hydrogasifier developed at the Institute of Gas Technology (IGT) with support from the U.S. Department of Energy and Minnegasco. In addition to SNG, a number of liquids are produced, including gasoline-blending stock (benzene, toluene, and xylene) and fuel oil, that have greater end-use flexibility. The distribution of products 
Table 13. Analyses of peat samples (moisture free)

\begin{tabular}{|c|c|c|c|}
\hline & $\begin{array}{l}\text { North } \\
\text { Carolina }\end{array}$ & Maineb & lesotac \\
\hline \multicolumn{4}{|l|}{ Proximate analyses } \\
\hline $\begin{array}{l}\text { Moisture as received }(\%) \\
\text { Volatile matter }(\%) \\
\text { Fixed carbon }(\%) \\
\text { Ash }(\%)\end{array}$ & $\begin{array}{r}61.8-93.3 \\
36.3-67.4 \\
21.6-39.5 \\
1.2-42.1\end{array}$ & $\begin{array}{r}82.0-94.9 \\
61.3-74.9 \\
24.3-33.0 \\
0.5-6.7\end{array}$ & $\begin{array}{l}- \\
65.0 \\
23.7 \\
11.3\end{array}$ \\
\hline \multicolumn{4}{|l|}{ Ultimate analyses } \\
\hline $\begin{array}{l}\text { Hydrogen (\%) } \\
\text { Carbon }(\%) \\
\text { Nitrogen (\&) } \\
\text { Sulfur }(\%) \\
\text { Oxygen }(\%)\end{array}$ & $\begin{array}{r}3.1-6.0 \\
36.1-64.2 \\
0.9-2.1 \\
0.1-0.5 \\
17.5-33.8\end{array}$ & $\begin{array}{r}4.8-5.9 \\
51.8-60.5 \\
0.5-2.2 \\
0.1-0.6 \\
26.5-40.7\end{array}$ & $\begin{array}{r}5.7 \\
49.9 \\
2.7 \\
0.3 \\
30.7\end{array}$ \\
\hline \multicolumn{4}{|l|}{ Heating value } \\
\hline $\begin{array}{l}\mathrm{MJ} / \mathrm{kg} \\
\mathrm{Btu} / \mathrm{Tb}\end{array}$ & $\begin{array}{l}13.6-25.9 \\
5860-11,180\end{array}$ & $\begin{array}{l}20.0-24.2 \\
8620-10,417\end{array}$ & $\begin{array}{l}19.8 \\
8506\end{array}$ \\
\hline \multicolumn{4}{|c|}{$\begin{array}{l}\text { aRange based on } 82 \text { samples of Pamlimarle Peninisula peat (Otte and } \\
\text { Ingram 1980). }\end{array}$} \\
\hline
\end{tabular}


can be controlled by regulating the temperatures in the hydrogasifier stage. Based on bench-scale and process development unit studies, maximum SNG production is obtained at relatively high temperatures $\left(760^{\circ} \mathrm{C}\right)$, while liquids production is limited to about $15 \%$ of the feed carbon. At approximately $540^{\circ} \mathrm{C}$, less $S N G$ is produced and direct liquid yields are about $30 \%$ of the feed carbon (Punwani et al. 1977).

The IGT has developed a process design for a complete SNG facility using Minnesota peat and producing $264 \times 10^{12} \mathrm{~J} / \mathrm{d}$ SNG (Fig. 9) (Arora and Tsaros 1980). This facility would require a daily input of $52 x$ $10^{9} \mathrm{~kg}$ of peat, of which $75 \%$ is process peat and the remainder is used for boiler and dryer fuel. Essentially all of the sulfur produced is converted into hydrogen sulfide and removed along with carbon dioxide in the acid gas removal system (Fig. 9). By-products include substantial amounts of benzene and crude aromatic oils as well as anhydrous ammonia and sulfur.

Additional research and development activities on peat gasification are being conducted by Rockwell International in the United States and by private and governmental agencies in Finland and the Soviet Union (Kopstein 1981, 1982; Punwani 1982).

\subsubsection{Biogasification}

An alternative approach to thermal gasification is the anaerobic digestion of peat to produce methane. Biogasification of peat is initiated by concentrating and pretreating a peat slurry with sodium carbonate and then partially oxidizing it to form a mixture of watersoluble aromatic compounds. This mixture is pumped to tanks where anaerobic fermentation occurs producing methane and carbon dioxide. Pipeline quality gas is produced by scrubbing to remove the carbon dioxide and hydrogen sulfide. The organic materials that are not solubilized in the pretreatment steps and the residual peat materials from the fermentation step can be concentrated and used as animal feed or as soil amendments. The advantages of biogasification are that (1) minimal dewatering is needed, (2) the pretreatment and fermentation steps operate at relatively low temperatures (e.g., $60^{\circ} \mathrm{C}$ ), and 


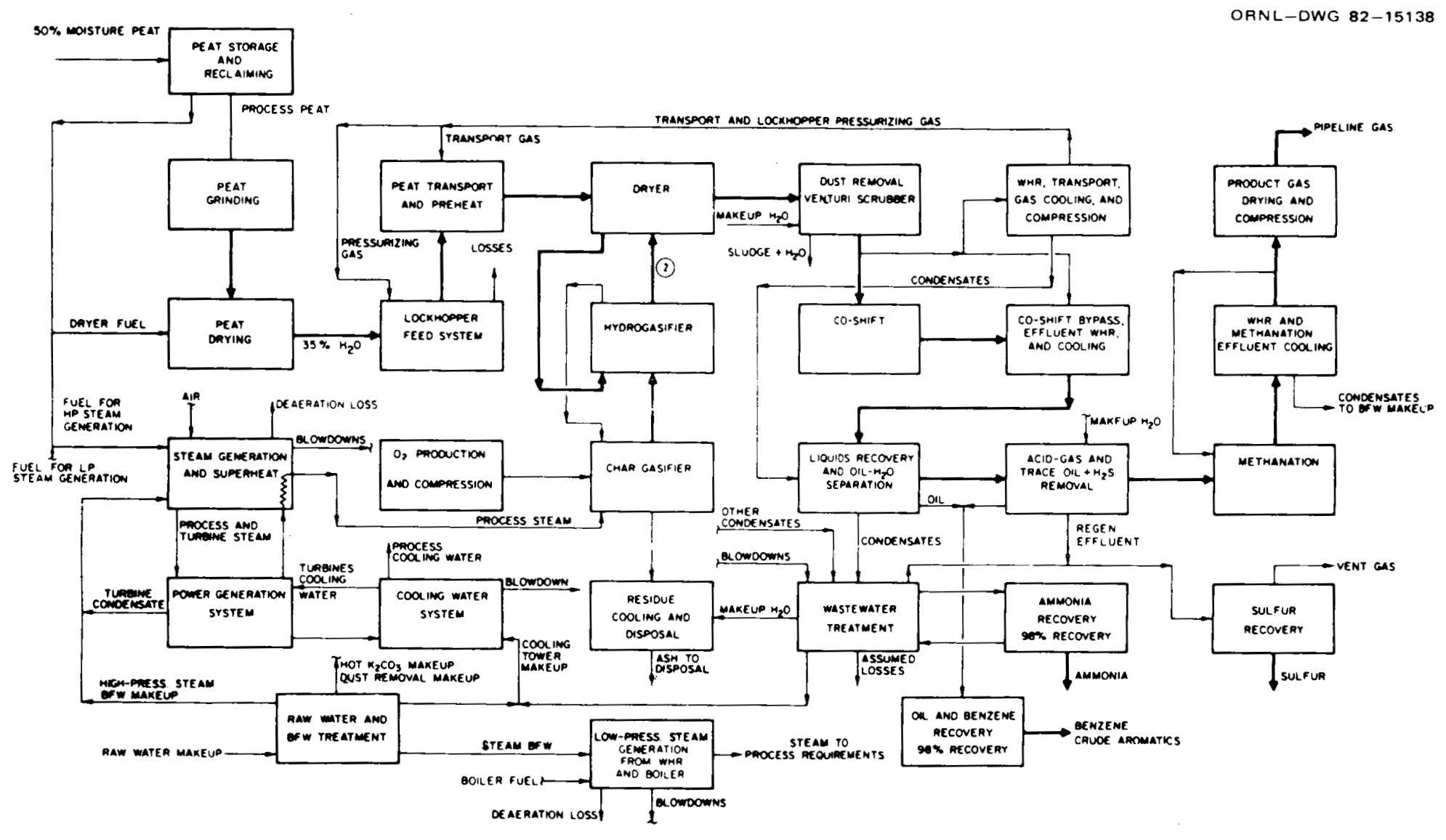

Fig. 9. Process design for Minnesota SNG plant (modified from Arora and Tsaros 1980). 
(3) waste streams appear to need minimal treatment. The major disadvantage is that the reactions are slow compared to thermal gasification. Although research on peat biogasification is in its earliest stages of development (Kopstein 1982), the technology for anaerobic digestion using other feedstocks (e.g., sewage sludges and industrial wastes) is well established (Ghosh 1980).

Experiments on in situ biogasification at peat bogs have been conducted in Sweden. Naturally produced methane is present in groundwater from the bogs and is pumped to a degassing station for separation. Although this approach involves low operating costs, the period during which favorable temperatures are present may limit the production potential. In addition, some consideration has been given to combining biological and thermal gasification processes. Digested peat from the biogasification process would be used as a feedstock to produce SNG in a thermal gasification process, thus avoiding the costly step of dewatering that would otherwise be required (Ghosh 1980).

\subsubsection{Liquids Production}

Liquid fuels can be produced from peat in several different ways (Kopstein 1982, Punwani 1982): (1) production of benzene during hydrogasification, (2) indirect liquefaction of synthesis gas (methanol) produced by thermal gasification, (3) direct liquefaction, and (4) conversion of peat to ethanol. The only technology that has commercial potential in the near term is the production of methanol by indirect liquefaction. Two commercial peat methanol plants having a capacity of $2500 \mathrm{~m}^{3} / \mathrm{d}$ are under construction in the Soviet Union, and plants of 1000 to $2000 \mathrm{~m}^{3} / \mathrm{d}$ are being evaluated in Finland (Solantausta and Asplund 1980). In North Carolina, construction of a peat methanol plant is being planned by Peat Methanol Associates (Rea 1981). This facility using peat from the First Colony Farms, Inc., would incorporate an entrained bed gasifier and have an initial capacity of $650 \mathrm{~m}^{3} / \mathrm{d}$. Methanol production in the United States is currently limited by the available market for the product. If methanol becomes an economic fuel or fuel additive, additional peat methanol 
projects are likely to be developed. The advantage of producing methanol and other liquid fuels from peat is that a more versatile product than SNG is produced (Mundale 1981).

\subsection{POTENTIALLY SIGNIFICANT ISSUES}

Peatlands are important components of regional ecosystems and significantly influence regional hydrology, water chemistry, and biota. Because they are often located at headwater or interstream positions of the landscape, peatlands affect regional runoff patterns by reducing subsurface water movement and by increasing overland flow. Peatlands act as nutrient sinks by assimilating nutrients in the surface vegetation and by retaining assimilated nutrients in the organic substrate and on the peat exchange complex. The chemistry of water moving over or through a peat deposit, therefore, can be significantly modified as nutrient exchange takes place. In addition, peatlands provide habitat for a variety of specialized plants and animals and are frequently the last remnants of undisturbed land within a region. These areas may provide important refuge, foraging, breeding, and nursery areas for a variety of wildlife species. Peatlands are often adjacent to and closely associated with other wetlands and aquatic ecosystems in a mutually interacting, complex pattern (Heinselman 1970, Glaser et al. 1981).

The following issues are those most likely to be significant for peatland projects and should be carefully reviewed. The content of this section is based primarily on two recent reviews of the peat literature (Reed et al. 1982a,b).

\subsubsection{Land Use}

Although peatlands are frequently regarded as being unproductive in their natural state, they are often used for agriculture, forestry, wildlife management, recreation, or wilderness areas. Conflicts may, therefore, arise if mining of such areas is proposed. In many parts of the country, peat soils have been drained and the land converted to high quality farmland. In North Carolina, for example, drainage and 
clearing of peatlands for agriculture is occurring rapidly (Richardson et al. 1981). In Scandinavia, drainage of organic soils is a common practice to promote reforestation. Because peatlands are of ten located in remote regions, they may provide important wildlife habitat or be parts of wildlife, recreational, and/or wilderness areas (e.g., the Boundary Water Canoe Area in Minnesota). In addition, peatlands representative of a region and/or supporting unusual species may have been set aside by government agencies or conservation groups as protected areas (Kivinen and Pakarinen 1981, Worley and Klein 1980).

The main use of peat in the United States is currently for horticultural purposes. In 1980, the United States produced $712 \times$ $10^{6} \mathrm{~kg}$ of peat for uses such as ingredients for potting soil, general soil improvement, mushroom beds, packing flowers, plants, shrubs, and vegetable growing (Davis 1980). Peat has also been used for a chemical feedstock, for medicinal purposes, for coke and charcoal production, and for treatment of municipal wastewaters (Kadlec 1978, Fuchsman 1980, Guntenspergen et a1. 1980).

The present land use of peatlands proposed for mining should be evaluated, and alternative uses should be described. Background information on land use should be developed to provide details on:

the existing 1 and use of the peatland to be mined and the areas to be occupied by proposed facilities for energy conversion;

- the past use of the peatland, including past attempts to drain it or use it for agriculture, forestry, etc.

- trends in development of peatlands for the region in which the peatland is located (e.g.s the North Carolina coastal plain);

- any other proposed uses for the peat deposit (e.g., production of sphagnum peat moss or commercial production of cranberries); 
- the impact of the project on surrounding land uses (e.g., conservation or cropland areas) during the lifetime of the proposed project and after reclamation has been implemented; and

conservation values associated with the peatland and efforts that have been made to preserve the peatland.

\subsubsection{Air Quality}

Most peatlands are located in remote, sparsely populated regions where air quality is generally good and the potential for significant deterioration is high. Air quality may be degraded by dust and fine debris produced by dry peat harvesting methods, especially the milled peat method. Because fine peat debris has a low specific gravity and irregular, fibrous shape, it may remain airborne for great distances (Conklin 1978). Draining a peatland dries out the surface and makes it susceptible to fire. The milled peat harvesting method is particularly susceptible to fire because of the finely divided product that is produced and dried on the bog surface. Machinery, a lightning strike, or a wildfire from surrounding areas can ignite a peat deposit, starting a fire that can burn out of control for long periods of time. The smoke from such a fire can degrade air quality throughout large areas (Conklin 1978). Drainage systems that permit the peat surface to be reflooded if a fire occurs can substantially reduce the risk and should be given serious consideration when developing drainage programs.

Compared to coal combustion, direct combustion of peat results in low sulfur and particulate emissions. The present technology of electrostatic precipitators should limit particulate emissions to acceptible levels (Punwani et a1. 1977, RTI 1979). Nitrogen oxide emissions, however, may exceed emission standards (King et al. 1980), and control of nitrogen gases may be required.

Atmospheric emissions from peat gasification plants will include carbon monoxide, hydrocarbons, particulates, sulfur dioxide, ammonia, hydrogen and organic sulfides, and perhaps trace elements such as mercury, beryllium, lead, arsenic, and selenium. Hydrogen sulfide and organic sulfide may cause local odor problems. 
Large-scale exploitation of peatlands may contribute to increases in atmospheric $\mathrm{CO}_{2}$ levels and projected climate changes resulting from these increases (Hansen et al. 1981). Globally, the organic carbon in peat reserves is estimated to be from 150 to $300 \mathrm{Pg} \mathrm{C}$ (Moore and Bellamy 1976, Bamryd 1979, Sjors 1980), slightly less than one-half that in the atmosphere as $\mathrm{CO}_{2}$. Oxidation of a significant portion of this reserve, either by direct conversion to usable energy or indirectly by widespread draining of peatlands for agricultural or other purposes, may contribute to an increase in atmospheric $\mathrm{CO}_{2}$. This issue, however, must be addressed at regional, national, and international levels rather than on the level of specific projects.

To evaluate the significance of atmospheric effects of proposed peat projects, the analysis should consider:

- the effects of dust and fine debris produced during peat harvesting operations on local and regional air quality;

- the potential for fires to occur, measures to minimize their occurrence, and plans for controlling them if they do occur;

- data on the predicted atmospheric dispersion of emissions from combustion or gasification facilities; and

- information on regional increases in atmospheric $\mathrm{CO}_{2}$ levels, and possible effects caused by the proposed facility.

\subsubsection{Hydrology}

Peatlands may form a perched water table and normally have an integral relationship to the groundwater hydrology of the surrounding region. Removal of peat from a deposit will lower the water table, modify the quantity and pattern of surface flow, and alter the water storage capacity of the former peatland (Boelter and Verry 1977, Brooks and Predmore 1978). The extent of this modification will depend on the type of drainage system developed and the water management program implemented after the peat has been mined. Removal of surface vegetation reduces evapotranspiration and may increase annual surface 
runoff. If the mined peatland is developed for agriculture, the infiltration characteristics of the mineral soil underlying the peat may be modified by cultivation practices, and subsurface flow could be affected. In coastal areas, modification of the hydraulic head associated with the peatland could lead to saltwater intrusion and the resultant contamination of existing freshwater aquifers (Heath 1975, Hughes 1979). Saltwater intrusion may also limit the agricultural potential of mined lands by raising the salinity of the reclaimed soils.

In addition to general baseline information on the affected environment, the analysis of impacts on hydrology should include consideration of:

- existing hydrology of the area in which the peatland is located;

- plans for draining the peat deposits;

- impacts of peat mining on existing surface and subsurface flows and associated aquifers;

- effects on ground and surface waters from use of the reclaimed peatland (e.g., from agricultural or silvicultural use); and

- the potential for the project to increase saltwater intrusion of freshwater aquifers in coastal areas.

\subsubsection{Water Quality}

Peat harvesting may cause significant deterioration of ground and surface water quality by erosion, release of nutrients and metals from peat oxidation, reduction in ecosystem retention of cations, and mobilization of elements from underlying mineral soils. The clearing of surface vegetation and harvesting operations will increase peat erosion, thereby increasing particulate loading to surface drainage waters (Crisp 1966, Gilliam and Skaggs 1981). The oxidation of adsorbed $\mathrm{NH}_{4}^{+}$accompanying peat drainage may release large quantities of $\mathrm{NO}_{3}^{-}$to receiving systems and encourage eutrophication (Given 1975). 
Because peat has a high cation exchange capacity and surface reactivity (Given 1975), its removal will reduce retention of atmospheric inputs and thus increase outputs of these cations to the receiving systems. In addition, removal of peat may expose the underlying mineral soil, thereby increasing the rate of weathering and nutrient release. The type of reclamation planned for the mined peatland can significantly influence the severity of such problems.

Liquid effluents from peat energy conversion facilities may include ammonia, phenols, sulfides, suspended solids, oxygen-demanding materials, and trace elements.

Potential project effects on water quality should be considered in detail. This analysis should include:

- evaluation of water quality changes (i.e., characterization of pollutants released from the peatland and from the conversion facilities), including identification of (1) the types and amounts of specific pollutants and (2) the aquatic systems receiving drainage or process waters from mined peatlands and from combustion and gasification facilities;

- identification and predicted releases of potentially toxic substances (e.g., heavy metals and organics) from the peatlands being mined, storage and waste disposal areas, and facility operations;

- $\quad$ plans for treating drainage and process waters; and

- evaluation of potential long-term water quality changes resulting from post-mining land use (e.g., agriculture or forestry).

\subsubsection{Solid Waste Disposal}

Solid wastes are produced in all phases of peat projects. During the clearing of a peatland, trees, shrubs, and other biomass residues are cut and generaliy require disposal. In some situations, these materials may be shredded and mixed with the surface layer of peat. This mixed layer is then harvested in the initial milling operation (Allen 1982). Alternatively, these biomass wastes may be removed from the peat 7 and and burned. 
Dewatering and pretreatment operations may produce some solid materials that are not used in energy conversion processes (e.g., the unsolubilized organic materials resulting from alkali pretreatment in biogasification). These materials are often used for fuel to generate process heat.

Peat combustion and gasification processes generate ash similar to that produced by combustion and gasification of coal (Sect. 4). Although the ash content of peat is comparable to that of coals, the greater volume of peat required to obtain the same energy output may result in a larger volume of ash. The ash may be used as a soil amendment during reclamation of mined peatlands, but the heavy metal content of some peats may preclude such use and require 1 andfill disposal of the ash. Biogasification of peat produces liquid effluents and sludges that contain high concentrations of nitrogen and trace elements. These wastes may require special treatment before discharge or disposal.

Background information describing the project and existing environment should be supplemented as necessary to permit a detailed evaluation of:

- the types and quantities of solid wastes produced during clearing, mining, pretreatment, and energy conversion steps;

- the physical and chemical composition of these wastes;

- the plans for disposal or use of the wastes; and

- the impacts of waste disposal on existing or newiy planned landfil1s; and

- the applicability of current federal, state, and local solid waste standards.

\subsubsection{Impacts on Biota}

Because peatlands are primarily found in remote and relatively undisturbed regions, they frequently provide important habitat for rare, threatened, endangered, and commercially important plants and 
animals. In Minnesota, for example, endangered and threatened species occurring in or using peatlands include 18 plant species and four animal species (MDNR 1981). Peatlands may provide specialized habitat conditions for some species with restricted distributions (e.g., orchids) (MDNR 1981). Big game populations such as moose in Minnesota (MDNR 1981) and black bear in North Carolina (Monschein 1981) may use peatland habitats for feeding and refuge from human disturbance. Cedar swamp habitats associated with Minnesota peatlands provide wintering yards for white-tailed deer and important habitat for birds (MDNR 1981). Peatlands are often closely associated with other wetlands that provide habitat for migratory waterfowl and animals such as reptiles and amphibians.

Harvesting peatlands can destroy special habitat conditions for species either directly by destroying the habitat itself or indirectly by modifying hydrological conditions or the water quality of habitats downstream from the harvested peatlands. Input of acidic peatland waters to downstream receiving systems during drainage and subsequent reclamation may adversely affect sensitive biota that are ecologically or economically important. In coastal regions, additions of $\mathrm{NO}_{3}^{-}$ may be particularly important because nitrogen is a limiting nutrient in estuaries and eutrophication may have an adverse effect on important shel1 fisheries, nurseries, and spawning grounds. Other adsorbed cations (Sect. 5.3.4), particularly metals, may also be released to surface waters during peat drainage and affect ecological processes in downstream receiving systems.

In addition to general descriptive information, data should be developed from a detailed survey of the plant and animal life of the affected peatland, emphasizing rare, threatened, and endangered species, species with highly specialized adaptations to the peatland habitat (e.g., orchids and bog lemmings), and commercially or recreationally important species (e.g., moose, bear, and furbearers) dependent on the peatland habitat. Any disruption to such species should be evaluated within the context of the status of regional 
populations and the presence of equivalent habitat that will be left undisturbed (Reed 1979).

\subsubsection{Impacts on Unique Ecosystems}

Peatlands have a number of unique features that may in specific cases argue for preservation rather than exploitation. In addition to providing habitat for rare and commercially important species (Sect. 5.3.6), peatlands may have scientific and educational values related to geological, biological, and hydrological developmental processes. For example, the "Big Bog" in Minnesota is the largest contiguous peatland in the conterminous United States $(116,550 \mathrm{ha})$.

As peat deposits develop, pollen grains from the peatland and surrounding areas are trapped and preserved in the organic sediments. Palynologists (i.e., specialists who study pollen grains preserved in peat profiles) can remove vertical cores from the peat deposits and reconstruct the types of pollen deposited in the vicinity of the peatland over the period of its development (e.g., up to 12,000 years). This type of study has contributed a great deal to the understanding of past changes in climate and vegetation (e.g., Amundson and Wright 1979, Whitehead 1972) and is currently being used to interpret the significance of past changes of atmospheric carbon dioxide levels in the biosphere (Auerbach et al. 1981, pp. 53-54). Because peatlands are sinks for nutrients and pollutants, they may also provide a long-term record of changes in vegetation and pollutant levels associated with atmospheric emissions. In areas of extensive peatland deposits, representative peatlands should be preserved to allow for future palynological studies. In many cases, where peat deposits are to be harvested, it may be appropriate to collect and preserve cores so that a record of regional variations in peatland features and development is preserved for future study.

The loss of wetlands has become an important national concern (Executive Order 11990 1977, CEQ 1978, Horwitz 1978), and federal and state governments have adopted policies to stem this loss and to avoid taking actions that would lead to the destruction or modification of 
wetlands. Peatlands are classified as wetlands by the U.S. Fish and Wildlife Service (Cowardin et al. 1979) and are often closely associated with other adjacent wetland areas. Extensive environmental review may be required by state and federal government agencies before permitting peat mining (U.S. DOE 1979b, 1981).

An assessment of the uniqueness of peatlands should be based on both a detailed evaluation of the peatland to be mined and an overall evaluation of similar and related regional ecosystems (Reed 1979).

\subsubsection{Reclamation}

The reclamation of harvested peatlands is considered by many to be a major advantage in using peat for energy because the "nonproductive" peatland can be converted to "productive" use (e.g., agriculture or silviculture). Such major changes in land use and disruption of existing ecosystems, however, can have major environmental consequences if reclamation is not adequately planned and achieved. Proposals for post-harvest 1 and use have included developing the site for cropland, pasture, forest production, or biomass energy plantations (Farnham 1978). Such uses require the installation and maintenance of permanent drainage systems and often involve intensive cultivation and other management practices. Potential environmental effects from these types of activities can include permanent alteration of freshwater flow regimes, increases in the sediment load to downstream receiving systems, addition of pesticides and herbicides to drainage waters, and permanent displacement of wildlife populations dependent on peatland habitat. In addition, cultivation of the mineral soils underlying the peat deposits could alter the porosity of the substrate and promote contamination of shallow aquifers. Harvested peatlands along the coastal plain of the Southeast may be at or below sea level and thus subject to saltwater intrusion and flood damage during major storms. If the harvested peatland is to be flooded permanently, construction of dikes may be required and management of water levels may be required to avoid disrupting established flow patterns. Although reclamation potential is high for many harvested peatlands, the development of new 
1and uses is accompanied by different environmental impacts, and their evaluation should be part of project planning.

The discussion and evaluation of proposed reclamation plans should include a detailed consideration of:

- impacts on water and air quality associated with the reclaimed land use;

- impacts on wildlife populations caused by permanent elimination of the mined peatland habitat;

- alternative reclamation possibilities and the rationale for selecting the proposed plan;

- long-term changes in surface and groundwater hydrology as compared to pre-project conditions; and

- available mitigation measures and proposed monitoring programs.

\subsubsection{Socioeconomics}

Most peat resources are located in relatively remote regions (Fig. 8) that are often economically depressed (RT1 1979, Radian Corp. 1980). Usually these regions have no other domestic fossil energy reserves, although biomass energy production is often feasible (RTI 1979). Usually these regions are net importers of electricity, natural gas, and other fuels. Development of peat energy projects is, therefore, seen as a positive economic stimulus.

The impact of peat energy projects on the local economy and communities must be carefuliy considered to avoid rapid population growth with its incumbent stress on the local suppiy of goods and services and potential decrease in quality of 1 ife. The extent of socioeconomic impacts will vary with project size and the region in which the project is located. Development of a number of small peatfired power plants throughout a region is unlikely to cause significant, long-term socioeconomic problems. However, large-scale facilities such as the $260 \times 10^{12} \mathrm{~J} / \mathrm{d}$ SNG plant proposed by the Minnesota Gas Company would employ large numbers of workers during construction and operation and would have major impacts on local communities. 
Potential benefits accruing from peat developments include increased employment, broader tax base, community improvements in a range of available services and facilities, and the stimulation of secondary businesses. These benefits, however, must be balanced against potential impacts such as housing shortages, strains on public services and utilities, symptoms of social stress, small business failures, water shortages, solid waste disposal problems, and perceived decrease in quality of 1 ife by some residents.

For large-scale peat projects where significant impacts are anticipated, analysis of the following types of project impacts may be needed:

- rapid population growth and subsequent decline caused by the project (i.e., boom and bust cycle);

- project-induced housing storages;

- public service shortfalls (including transportation impacts);

- temporal and jurisdictional dissociations of costs and benefits for local governments;

- institutional, economic, and social effects of 1 and use changes, solid waste disposal needs, and competition for water;

- significant changes in political, economic, and social structures, with special consideration of their effects on the life-styles of residents;

- community disruption or project delays resulting from local opposition to and support of the proposed project; and

- project-induced special needs such as occupational health problems and demand for psychological counseling.

The analysis should also consider the socioeconomic impacts of secondary developments such as industries developed to supply the peat facility and to market by-products such as sulphur. Long-term effects should be contrasted with immediate impacts. Possible concerns to be 
considered include long-term constraints on local and regional development as the peat facility competes for water, contributes to air quality degradation, etc.

Given present uncertainties, attention should be given to the institutional, legal, and economic aspects of health problems (Sect. 5.3.10) posed by the proposed peat combustion or gasification facilities. Popular and institutional perceptions of risks to workers and to neighbors should be considered. Controversy could develop over such perceptions of health risks as well as other issues of environmental degradation. Federal and state regulatory requirements and potential legal issues (e.g., water availability or surface mining rights) should be noted. Local attitudes toward all issues should be obtained directly whenever possible. The development of communication channels between resident groups, developers, and governmental bodies is highly desirable.

Significant degradation of existing aesthetic, historic, cultural, and archaeological resources could result from project-related mining, construction, air and water degradation, road traffic, peat and product transportation, and secondary developments. Effects of odor and noise on residents should be considered (noted). Visual concerns should be addressed, with consideration of such features as cooling towers, new power and pipelines, reclamation plans, and secondary commercial and population growth activities.

Finally, in cases where significant adverse impacts are likely to occur, special emphasis should be placed on identifying the amount and sources of funds available for implementing mitigation measures.

\subsubsection{Health and Safety}

In general the health and safety issues associated with using peat for energy will be similar to those for coal. Peat mining is essentially a surface mining operation, and the principal hazards are those associated with the operation of large equipment. Peat deposits are generally on flat, wet terrain, and the hazards of rock falls and slumping of overburden piles associated with coal mining are not 
present. Drained peatlands are susceptible to fire caused by lightning, sparks from equipment, or the spread of wildfires from surrounding lands. Dry harvest operations involve considerable fugitive dust, and equipment operators should be protected from inhalation of these materials.

A major concern in handling and processing dry peat for either direct combustion or peat gasification is the hazard of dust explosions and fire. Careful manipulation of moisture content and elimination of ignition sources can reduce this hazard considerably. Peat stockpiles must be properly formed to limit the danger of spontaneous combustion (Jones 1979). First Colony Farms, Inc., found that moisture content of stockpiles does not change appreciably except in the surface layer and protection from rewetting is not required.

Although there is little information available on emissions and products from peat gasification processes, health risks should be essentially similar to those from coal gasification facilities. Section 4 reviews the risks to workers and the public from exposure to potentially toxic and carcinogenic emissions from coal gasification. Substances of particular concern include polynuclear aromatics, phenols, thiophenes, aromatic amines, benzene, and soluble heavy metal compounds and complexes (King et al. 1980).

The analysis of health and safety issues should evaluate the following issues as appropriate to the proposed project:

- exposure of workers to fugitive dust in harvesting, handling, and processing of mill and sod peat;

- prevention and control of fires on peatlands being mined;

- prevention and control of explosion and fire in the handling, transportation, and processing of dry peat for combustion and gasification;

- exposure to PAH's and other potential carcinogens and mutagens released during gasification processes;

- exposure to potentially toxic materials emitted during pretreatment and processing of peat; 
- acute effects such as inhalation, severe respiratory irritation, and chemical and thermal burns in workers exposed to fugitive emissions, leaks, and spills;

- exposure to synthetic crude products which have been found to be more carcinogenic than natural crudes and which contain polycyclic aromatic amines that exhibit exceptionally high mutagenicities;

- exposure to high noise levels associated with peat harvesting and plant operations; and

- worker exposure to the risks involved in operating and maintaining large harvesting machinery using cutting blades, macerators, etc. 


\subsection{REFERENCES}

Allen, A. B. 1982. Production of fuel grade peat at First Colony Farms, Inc. pp. 135-150. IN Proc., Peat as an Energy Alternative II. Institute of Gas Technology, Chicago, Illinois.

Amundson, D. C., and H. E. Wright, Jr. 1979. Forest changes in Minnesota at the end of the Pleistocene. Ecol. Monogr. 49(1):1-16.

Arora, J. L., and C. L. Tsaros. 1980. Experimental Program for the Development of Peat Gasification. FE-2469-49. U.S. Department of Energy, Washington, D.C.

Auerbach, S. I., et al. 1981. Environmental Sciences Division Annual Progress Report for Period Ending September 30, 1980. ORNL-5700. Oak Ridge National Laboratory, 0ak Ridge, Tennessee.

Bamryd, T. 1979. The conservation of peatlands as global carbon accumulators. pp. 297-305. IN Proc., Interntational Symposium on Classification of Peat and Peatlands. International Peat Society, Helsinki, Finland.

Boelter, D. H., and E. S. Verry. 1977. Peatland and Water in the Northern Lake States. U.S.D.A. Forest Service, General Technical Report NC-31. North Central Forest Experiment Station, St. PauT, Minnesota.

Brooks, K. E., and S. R. Predmore. 1978. Phase II: Hydrologic Factors of Peat Harvesting. University of Minnesota, Department of Forest Resources, St. Paul, Minnesota.

Brophy, M. 1982. A resume of Irish experience and practice in the firing of peat in power station boiler plants. pp. 417-434. IN Proc., Peat as an Energy Alternative II. Institute of Gas Technology, Chicago, Illinois.

Cameron, C. C. 1980. Variety in United States peat deposits. pp. 12-15. IN Proc., 6th International Peat Congress. International Peat Society, Helsinki, Finland.

Campbe11, R. N., Jr. 1981. Peat for energy program: First Colony Farms, Inc. pp. 214-224. IN C. J. Richardson (ed.), Pocosin Wet lands. Hutchinson Ross Publ. Co., Stroudsburg, Pennsylvania.

Conklin, M. H. 1978. The Potential Air Quality Impacts of Harvesting Peat in Northern Minnesota. Minnesota Department of Natural Resources, St. Paul, Minnesota. 
Council on Environmental Quality (CEQ). 1978. Environmental quality: The Ninth Annual Report of the Council on Environmental Quality. Washington, D.C.

Cowardin, L. M., V. Carter, F. C. Golet, and E. T. LaRoe. 1979. Classification of Wetlands and Deepwater Habitats of the United States. FWS/OBS-79/31. U.S. Fish and Wildlife Service, Washington, D.C.

Crisp, D. T. 1966. Input and output of minerals for an area of Pennine Moorland: The importance of precipitation, peat erosion, and animals. J. Appl. Ecol. 3(2):327-348.

Davis, C. L. 1980. Peat. The 1980 Bureau of Mines Minerals Yearbook. U. S. Department of Interior, Washington, D.C.

Edelman, R. A., and R. K. Manfred. 1982. Planning for electric generation using fuel peat. pp. 627-651. IN Proc., Peat as an Energy Alternative II. Institute of Gas Technology, Chicago, Illinois.

Executive Order No. 11990. 1977. Protection of Wetlands. Fed. Regist. 42:26961 (May 24, 1977).

Farnham, R. S. 1978. Wetlands as energy sources. pp. 661-672. IN P. E. Greeson, J. R. Clark, and J. E. Clark (eds.), Wetland Functions and Values: The State of our Understanding. American Water Resources Association, Minneapolis, Minnesota.

Farnham, R. S. 1980. Peat resources update - Potential for development. pp. 29-36. IN Peat as an Energy Alternative. Institute of Gas Technology, Chicago, Illinois.

Fuchsman, C. H. 1980. Peat: Industrial Chemistry and Technology. Academic Press, New York. 279 pp.

Ghosh, S. 1980. Biogasification of pretreated reed-sedge peat. pp. 192-197. IN Proc. 6th International Peat Congress. International Peat Society, Helsinki, Finland.

Ghosh, S., and D. L. Klass. 1979. Biomethanation of Minnesota reed sedge peat. Resour. Recov. Conserv. 4:115-139.

Gilliam, J. W., and R. W. Skaggs, 1981. Drainage and agricultural development: Effects on drainage waters. pp. 109-124. IN C. J. Richardson (ed.). Pocosin Wetlands. Hutchinson Ross Publ. Co., Stroudsburg, Pennsylvania. 
Given, P. H. 1975. Environmental organic chemistry of bogs, marshes, and swamps. pp. 55-80. IN Environmental Chemistry. The Chemical Society, Burlington House, London.

Glaser, P. H., G. A. Wheeler, E. Gorham, and H. E. Wright, Jr. 1981. The patterned mires of the Red Lake Peatland, northern Minnesota: Vegetation, water chemistry and landforms. J. Ecol. 69(2):575-599.

Gutenspergen, G., W. Kappe 1, and F. Sterns. 1980. Response of a bog to application of lagoon sewage: The Drummond project - an operational trial. pp. 559-562. IN Proc. 6th International Peat Congress. International Peat Society, Helsinki, Finland.

Hansen, J., D. Johnson, A. Lacis, S. Lebedeff, P. Lee, D. Rind, and G. Russe1. 1981. Climate impact of increasing atmospheric carbon dioxide. Science 213(4511):957-966.

Heath, R. C. 1975. Hydrology of the Albemarle-Pamlico Region, North Carolina, a Preliminary Report of the Impact of Agricultural Developments. U.S.G.S. Water Resources Investigations 9-75. U.S. Geological Survey, Washington, D.C.

Heinselman, M. L. 1970. Landscape evolution, peatland types, and the environment in the Lake Agassiz Peatlands Natural Area, Minnesota. Ecol. Monogr. 40(2):235-261.

Horwitz, E. L. 1978. Our nation's wetlands: An Interagency Task Force report. Council on Environmental Quality, Washington, D.C.

Hughes, J. L. 1979. Saltwater-barrier line in Florida: Concepts, considerations, and site examples. Water Resources Investigations 79-75. U.S. Geological Survey, Water Resources Division, Tallahassee, Florida.

Jones, W. J. 1979. Peat as a Fuel at the Proposed Central Maine Power Company $600 \mathrm{MW}$ Plant. MIT-EL 79-012. Energy Laboratory, Massachusetts Institute of Technology, Boston, Massachusetts.

Kadlec, R. H. 1978. Wetlands for tertiary treatment. pp. 490-504. IN P. E. Greeson, J. R. Clark, and J.E. Clark (eds.), Wet land Functions and Values: The State of our Understanding. American Water Resources Association, Minneapolis, Minnesota.

King, R., S. Richardson, A. Walters, L. Boesch, W. Thomson, and J. Irons. 1980. Preliminary Evaluation of Environmental Issues on the Use of Peat as an Energy Resource. Report No. TR-80/025-001 to U.S. Department of Energy. UOP, Inc., and Systems Development Corp., McLean, Virginia. 
Kivinen, E., and Pakarinen, P. 1980. Peatland areas and the proportion of virgin peatlands in different countries. pp. 52-54. IN Proc., 6th International Peat Congress. International Peat Society, Helsinki, Finland.

Kopstein, M. J. 1981. DOE peat development program. Paper presented at the Symposium on Peat as an Energy Alternative II (Dec. 1-3, 1981, Arlington, Virgina). Institute of Gas Technology, Chicago, Illinois.

Kopstein, M. J. 1982. Peat processing research. pp. 727-735. IN Proc., Peat as an Energy Alternative II. Institute of Gas Technology, Chicago, Illinois.

Lindstrom, 0. 1980. The technology of peat. Ambio 9(6):309.

Mayer, G. G., and Christianson, L. L. 1982. Overview of state peat resource assessment program. pp. 65-90. IN Proc., Peat as an Energy Alternative II. Institute of Gas Technology, Chicago, Illinois.

Minnesota Department of Natural Resources (MDNR). 1981. Minnesota Peat Program Final Report. Division of Minerals, St. Paul, Minnesota.

Monschein, T. D. 1981. Values of pocosins to game and fish species in North Carolina. pp. 155-170. IN C. J. Richardson (ed.), Pocosin Wetlands, An Integrated Analys is of Coastal Plain Freshwater Bogs in North Carolina. Hutchinson Ross Publ. Co., Stroudsburg, Pennsylvania.

Moore, P. D., and D. J. Bellamy. 1976. Peatlands. Springer-Verlag, New York.

Mundale, S. M. (ed.). 1981. Energy from Peatlands: Options and Impacts. Pub1. No. CURA 81-2. University of Minnesota Center for Urban and Regional Affairs, Minneapolis, Minnesota.

Otte, L. J., and R. L. Ingram. 1980. 1980 Annual Report on Peat Resources of North Carolina. Report DE-AC01-79ET-14693 to North Carolina Energy Institute and the U.S. Department of Energy. University of North Carolina, Chapel Hill, North Carolina.

Paganessi, J. E., C. Sishtla, T. M. Knowlton, D. V. Punwani, and W. W. Bodle. 1980. Solvent extraction dewatering of peat. pp. 215-225. IN Peat as an Energy Alternative. Institute of Gas Technology, Chicago, Illinois. 
Punwani, D. V. 1982. Peat as an energy alternative: 1981 update. pp. 1-27. IN Proc., Peat as an Energy Alternative II. Institute of Gas Technology, Chicago, Illinois.

Punwani, D.V., A. M. Rader, and M. J. Kopstein. 1980. Synthetic fuels from peat by the IGT Peatgas process. pp. 294-308. IN Proc., 6th International Peat Congress. International Peat Society, Helsinki, Finland.

Punwani, D. V., W. W. Bodle, P. B. Tarman, and A. M. Rader. 1977. Synthetic natural gas production from peat, Vol. 7 , pp. 3087-3112. IN Alternative Energy Sources, An International Compendium. Hemi sphere Publication Corp., Washington, D.C.

Radian Corporation. 1980. Socioeconomic issues associated with use of peat as an energy resource. Report DCN 80-217-151-17-03. Prepared for Division of Fossil Fuel Processing, U.S. Department of Energy, Washington, D.C.

Rea, R. H. 1982. Peat as a source of methanol. pp. 653-669. IN Proc., Peat as an Energy Alternative II. Institute of Gas Technology, Chicago, Illinois.

Reed, R. M. 1979. Identification of unique ecological features in environmental impact assessments. pp. 509-511. In Proc., 25th Annual Technical Meeting of the Institute of Environmental Sciences. Institute of Environmental Sciences, Mt. Prospect, Illinois.

Reed, R. M., L. D. Voorhees, and P. J. Mulholland. 1982a. Environmental impacts associated with using peat for energy. pp. 1571-1580. IN Proc., 1981 International Gas Research Conference. Government Institutes, Inc., Rockville, Maryland.

Reed, R. M., L. D. Voorhees, and P. J. Mullholland. 1982b. Using peat for energy: Potential environmental constraints. pp. 675-691 IN Proc., Peat as an Energy Alternative II. Institute of Gas Technology, Chicago, Illinois.

Research Triangle Institute (RTI). 1979. Impact and feasibility of wood- or peat-fired electric generating plants in the coastal zone of North Carolina. Report No. RTI 23U-1777. Research Triangle Park, North Carolina.

Richardson, C. J., R. Evans, and D. Carr. 1981. Pocosins: An ecosystem in transition. pp. 3-19. IN C. J. Richardson (ed.), Pocosin Wetlands, An Integrated Analysis of Coastal Plain Freshwater Bogs in North Carolina. Hutchinson Ross Publ. Co., Stroudsburg, Pennsylvania. 
Sjors, H. 1980. Peat on earth: Multiple use or conservation. Ambio $9(6): 303$.

Smith, R. T. 1981. Environmental Aspects of Alternative Wet Technologies for Producing Energy/Fuel from Peat. Final Report DOE/FC/10169-T1. Energy Resources Co., Inc., Walnut Creek, California.

Solantausta, Y., and D. Asplund. 1980. Methanol from peat. Technical and economic aspects in Finland. pp. 525-553. IN Peat as an Energy Alternative. Institute of Gas Technology, Chicago, Illinois.

Tomiczek, P. W., Jr., J. D. Phillips, and W. Hudak, Jr. 1981. Potential peat harvesting alternatives. pp. 119-133. IN Proc., Peat as an Energy Alternative II. Institute of Gas Technology, Chicago, Illinois.

Tsaros, C. L. 1982. Peat dewatering, an overview. pp. 199-216. IN Proc., Peat as an Energy Alternative II. Institute of Gas Technology, Chicago, Illinois.

U.S. Department of Energy (U.S. DOE). 1979a. Peat Prospectus. Division of Fossil Fuel Processing, Washington, D.C.

1979b. Department of Energy compliance with floodplain/wetlands environmental review requirements. Fed. Regist. 44(46):12594-12599.

1981. Environmental Compliance Guide. DOE/EV-0132, 2 vols. Office of Environmental Compliance and Overview, Washington, D.C.

Whitehead, D. R. 1972. Developmental and environmental history of the Dismal Swamp. Ecol. Monogr. 42(3):301-315.

Worley, I. A., and R. Klein. 1980. Protection and preservation of peatlands as natural areas in the northeastern United States. pp. 149-152. IN Proc., 6th International Peat Congress. International Peat Society, Helsinki, Finland. 
Kathleen M. Oakes ${ }^{1}$ and Elizabeth L. Etnier ${ }^{2}$

\subsection{RESOURCE DESCRIPTION}

Unconventional natural gas is the term applied to gas that exists in reservoirs that are marginal to unfavorable for production of gas at current market prices, using conventional recovery methods. Natural gas provides about $30 \%$ of the nation's total energy requirement, but proven domestic gas reserves and annual gas production have declined over the past decade (Kuuskraa et al. 1978). Currently, unconventional gas sources contribute about $28 \times 10^{9} \mathrm{~m}^{3}[1$ Tcf (trillion cubic feet)] of natural gas annually, which is about $5 \%$ of the domestic gas production (NPC 1980). Gas from unconventional sources could add significantly more to U.S. reserves within the century.

Figure 10 shows the location of major U.S. unconventional gas resources, of which there are four categories: (1) gas present in tight, or low permeability, sandstone formations in the West, (2) free gas present within Devonian-age shale formations in the East, (3) methane associated with coal seams, and (4) methane dissolved in geopressured aquifers located along the Texas-Louisiana Gulf Coast. Two recent studies explored the potential of unconventional gas (Kuuskraa et al. 1978, NPC 1980). Table 14 presents estimates from these studies of gas-in-place and recoverable resources from each of the four categories of unconventional sources of natural gas.

\subsubsection{Western Tight Gas Sands}

The most promising source of unconventional gas is sand reservoirs of low permeability, termed tight gas sands, located in several western sedimentary basins (Fig. 10). The gas-bearing sands in the basins are interbedded with unproductive clays and shales over intervals as thick

\footnotetext{
IEnvironmental Sciences Division, ORNL. ${ }^{2}$ Health and Safety Research Division, ORNL.
} 
Table 14. Estimates of gas-in-place and economically recoverable gas resources from unconventional sources of natural gas [in $10^{9} \mathrm{~m}^{3}$ and trilion cubic feet (Tcf); estimates of economically recoverable resources are for base case technology and lowest economic return and advanced technology and highest economic return]

\begin{tabular}{|c|c|c|c|}
\hline & \multicolumn{3}{|c|}{ Unconventional gas in $10^{9} \mathrm{~m}^{3}$ (Tcf) } \\
\hline & \multirow[t]{2}{*}{ Gas in place } & \multicolumn{2}{|c|}{ Economically recoverable resources } \\
\hline & & $\begin{array}{c}\text { Base case technology return } \\
\text { Lowest }\end{array}$ & $\begin{array}{c}\text { Advanced technology return } \\
\text { Highest }\end{array}$ \\
\hline $\begin{array}{l}\text { Western tight gas sands } \\
\text { (Kuuskraa et al. 1978) } \\
\text { (NPC 1980) }\end{array}$ & $\begin{aligned} 11,600 & (409) \\
12,600-26,200 & (444-924)\end{aligned}$ & $\begin{array}{l}2,000(70) \\
5,400(192)\end{array}$ & $\begin{array}{r}5,300(188) \\
16,200(574)\end{array}$ \\
\hline $\begin{array}{l}\text { Devonian gas shales } \\
\text { (Kuuskraa et al. 1978) } \\
\text { (NPC 1980) }\end{array}$ & $\begin{aligned} 2,260 & (80)^{a} \\
11,000-57,300 & (387-2023)^{b}\end{aligned}$ & $\begin{array}{l}57(2) \\
85(3)\end{array}$ & $\begin{array}{r}708(25) \\
1,104(39)\end{array}$ \\
\hline $\begin{array}{l}\text { Methane from coal seams } \\
\text { (Kuuskraa et al. 1978) } \\
\text { (NPC 1980) }\end{array}$ & $\begin{array}{l}13,600(480)^{c} \\
11,300(398)\end{array}$ & $\begin{array}{cl}0 & d \\
142 & (5)\end{array}$ & $\begin{array}{l}57-708(2-25)^{d} \\
1,275(45)\end{array}$ \\
\hline $\begin{array}{l}\text { Methane from geopressured aquifers } \\
\text { (Kuuskraa et al. 1978) } \\
\text { (NPC 1980) }\end{array}$ & $39,600(1400)$ & $\begin{array}{l}0 f \\
0\end{array}$ & $\begin{aligned} 28-142 & (1-5) \\
9-18 & (0.3-0.6)\end{aligned}$ \\
\hline
\end{tabular}

${ }^{\mathrm{a}}$ Free gas only, does not include gas "locked" into kerogen structure.

${ }^{\mathrm{b}}$ Includes all gas -- free and that present in kerogen.

${ }^{C}$ Minable coal seams $-8775 \times 10^{9} \mathrm{~m}^{3}$ (310 Tcf), unminable $4810 \times 10^{9} \mathrm{~m}^{3}$ (170 Tcf), from Kuuskraa (1981).

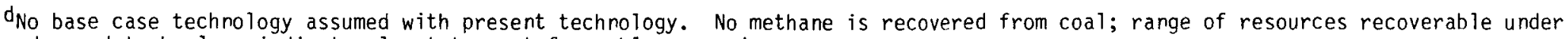
advanced technology indicates least to most favorable economics.

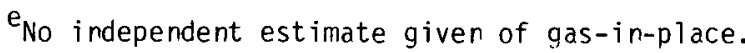

fNo methane will be recovered with base case technology; the estimates for recoverable resources with advanced technology are for a range of economic returns. 


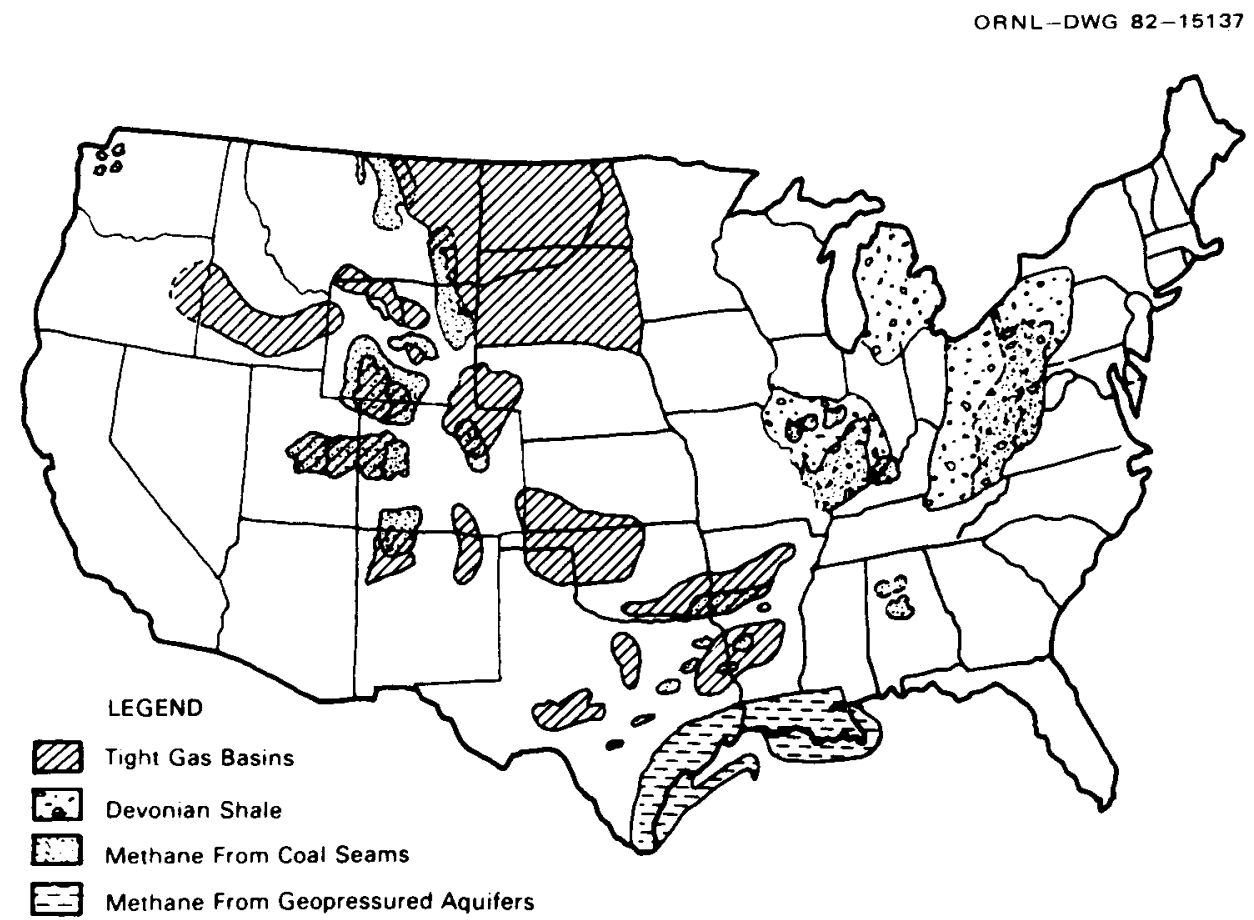

Fig. 10. Unconventional gas resources of the United States (U.S. DOE 1980). 
as $5000 \mathrm{~m}$. The thicknesses of the sand reservoirs range from a few meters to over $30 \mathrm{~m}(100 \mathrm{ft})$. The thicker blanket-type sand reservoirs, which exhibit continuity over a relatively large area, are the most promising for gas production. In many basins, however, the gas-producing sands are thin and unpredictably discontinuous, due to their lenticularity (lens-like nature). A single well may penetrate up to 100 of these production layers (Riedel et al. 1980).

Current domestic annual production of unconventional gas from tight gas sands is about $22.5 \times 10^{9} \mathrm{~m}^{3}$ (0.8 Tcf) (NPC 1980). The main limitation on gas production from tight sands is their low permeability (by definition less than 1 millidarcy), resulting in uneconomically low rates of gas flow into the well. Favorable production rates are achievable by fracturing the formations to create a large area around the well bore into which the gas will flow. A major thrust of R\&D in unconventional gas recovery is in developing advanced methods of formation fracturing (Sect. 6.2.2).

\subsubsection{Eastern Devonian Gas Shales}

Devonian-age shales of primary interest for unconventional gas recovery underlie the Appalachian, Michigan, and Illinois structural basins in the eastern United States (Fig. 10). These are black and brown shales of marine origin containing an organic substance, kerogen, that is the source of natural gas (Kuuskraa et al. 1978). The gas is present both as free gas, recoverable by drilling, and as gas "locked" into the kerogen, recoverable by retorting of the shale to convert the hydrocarbons to synthetic gas and oil (Kuuskraa et al. 1978). Only the mobile (or free) gas is being considered here for unconventional gas recovery. Between 2 and $6 \times 10^{12} \mathrm{~m}^{3}$ (80 to $225 \mathrm{Tcf}$ ) of gas may be present as free gas-in-place in Devonian shales (NPC 1980, Kuuskraa et a1. 1978).

Throughout this century, gas has been produced from Devonian shales in northern Ohio and in the Big Sandy Field of Kentucky (Kuuskraa et a1. 1978). Present production is about $6 \times 10^{9} \mathrm{~m}^{3}(0.2$ Tcf) annually (NPC 1980). Gas production from most of the shales is 
marginal due to low formation permeability and a low incidence of naturally occurring fractures. Current recovery methods include directional drilling to intersect natural fracture systems and stimulation of wells with small-scale explosive fracturing, termed "shooting."

\subsubsection{Methane from Coal Seams}

Methane gas, a natural product of coal formation, may be found in varying quantities in most coal seams. Interest in coal-bed methane as a gas resource grew out of research to reduce the safety hazard of methane in underground coal mines, particularly in the "gassy" bituminous coals of the eastern United States (Ethridge et al. 1980). About $2 \times 10^{6} \mathrm{~m}^{3} \quad[73$ MMcf (million cubic $\mathrm{ft}$ )] of methane is currently vented each year from operating coal mines (Ethridge et al. 1980); none is recovered. Minable coal seams in the United States contain an estimated $8.5 \times 10^{12} \mathrm{~m}^{3}$ (310 Tcf) of methane (Kuuskraa et al. 1978, NPC 1980). Coal seams that are too deep or too thin to mine contain an additional $5 \times 10^{12} \mathrm{~m}^{3}$ (170 Tcf) of methane (Table 14).

Methane from coal seams may involve some unique institutional and legal considerations. The ownership of the gas may be disputed in cases where the oil and gas rights and coal rights to an area are held separately (Ethridge et a1. 1980). Also, the classification of coal seam gas is an issue that could affect regulations concerning production and sale of the gas (Ethridge et al. 1980). The regulations that apply to natural gas may be appropriately applied to methane from unminable coal seams, but special regulations for the production of methane from minable coal seams may be necessary to take into account the safety of future mines in the coal seam (Ethridge et al. 1980).

\subsubsection{Methane from Geopressured Aquifers}

Geopressured aquifers, underground reservoirs of hot salt water existing under great pressures, are known to contain dissolved methane. Geopressured aquifers that present the best possibility for 
resource production are located in a band approximately 80 to $100 \mathrm{~km}$ (50 to 70 miles) wide, straddling the Gulf Coast of Texas and Louisiana (NPC 1980). Early estimates of gas-in-place in geopressured aquifers (Papadopulos et al. 1975, Jones 1976) indicated a vast resource of up to $1.5 \times 10^{15} \mathrm{~m}^{3}(50,000 \mathrm{Tcf})$, but later information reduced these estimates by about two orders of magnitude (Samuels 1980). Recent geopressure well tests indicate that the brines are saltier and not as hot as earlier expected. Both these factors adversely affect methane solubility. Indications are that the brines may contain about 3.5 to $4.5 \mathrm{~m}^{3}$ methane $/ \mathrm{m}^{3}$ brine (20 to $25 \mathrm{scf} / \mathrm{bbl}$ ) at saturation (Samuels 1980). Recovery of the methane may be coupled with production of electricity from the hot brines. Recovery costs for methane from geopressured aquifers are estimated to be $\$ 0.18$ to $\$ 0.35 / \mathrm{m}^{3}$ of gas [\$5.00 to $\$ 10.00$ Mcf (thousand cubic feet)] (Samuels 1980), which may be compared with the current market price for natural gas of about $\$ 0.07 / \mathrm{m}^{3}$ (\$1.75/MCf) (EIA 1987).

\subsection{TECHNOLOGY OVERVIEW}

Recovery of gas from unconventional sources will involve several methods common to all four types of resources, including drilling, well testing, and gas production. All sources, except perhaps geopressured aquifers, may require well stimulation by fracturing of the formation. Those techniques common to all unconventional gas projects are described below, followed by brief descriptions of resource-specific recovery methods.

\subsubsection{Drilling}

Drilling techniques are essentially the same for all four types of unconventional sources of gas. The major differences will be in the number, type, and depth of the wells (see following resource-specific sections). Drilling is by conventional rotary methods using a platform-mounted drill rig (Fig. 11). Rotary drilling is accomplished by rotating a cutting drill bit at the end of a length of drill pipe, through which is circulated a lubricating and cooling fluid, termed 


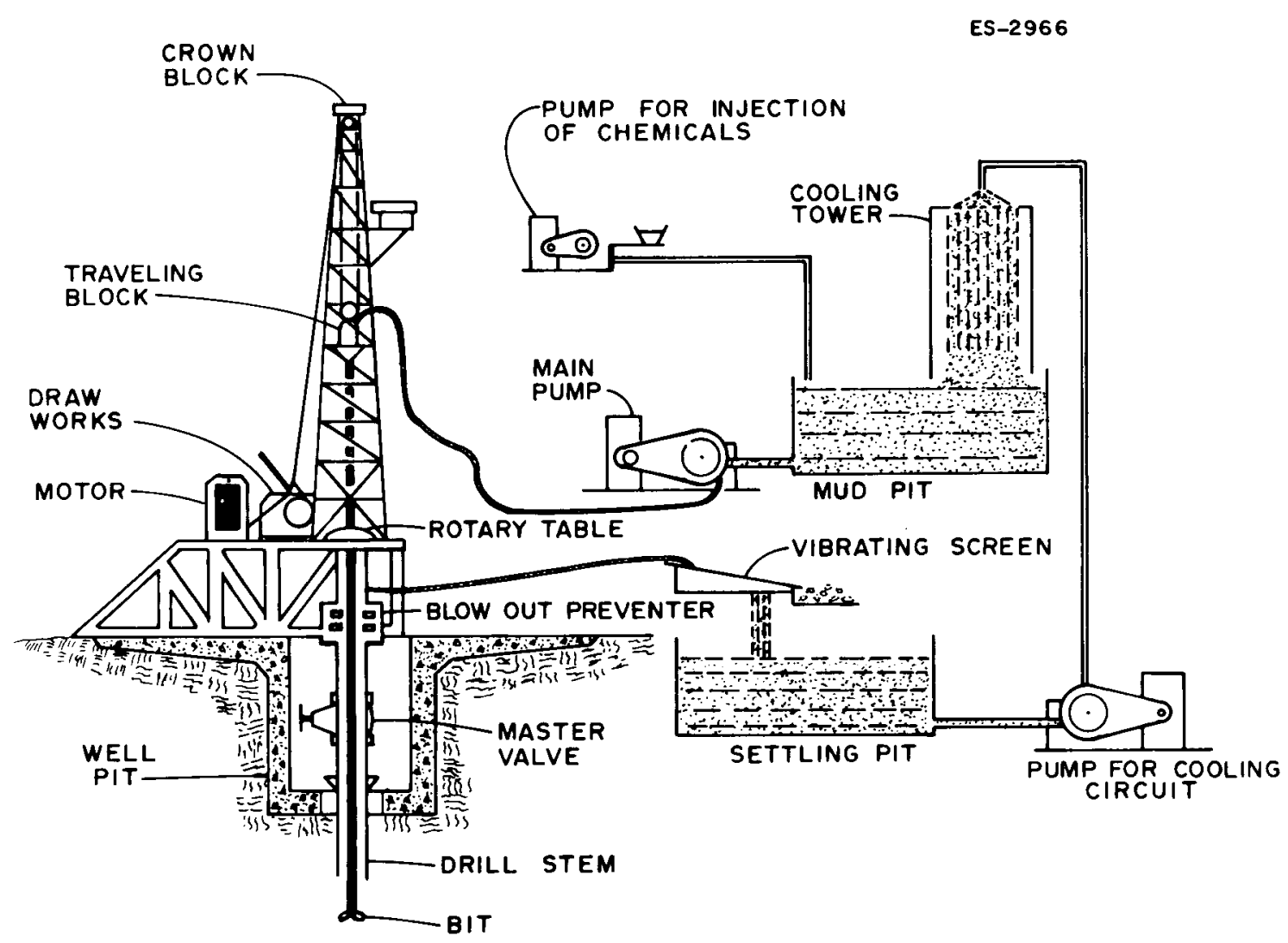

Fig. 11. Typical platform-mounted rotary drilling rig (U.S. ERDA 1977a). 
drilling mud. The mud is a water-based slurry containing clays, chemical additives to maintain viscosity and density, detergents for lubrication, and caustic soda. The mud is recirculated and cooled in mud tanks, and the formation cuttings are removed and stored in a reserve pit excavated adjacent to the rig. Blowout preventers are installed on many wells during drilling and maintained throughout the life of the well. After drilling is completed, casing is set and cemented to appropriate depths to isolate different production zones, keep the integrity of the well bore, and protect any freshwater zones.

Site preparation for drilling involves clearing and leveling a pad for the drill platform and excavating a reserve pit. The drill pad and pit may occupy between 0.5 and 2 ha ( 1 to 5 acres). Additional 1 and may be occupied by fuel and water storage tanks, holding ponds for produced fluids, and equipment storage. Access roads may be constructed for the rig and other equipment.

\subsubsection{Advanced Fracturing Methods}

Most unconventional gas resources are uneconomic because of their limited flow capacity. Fracturing the gas-bearing formation increases the well bore drainage area, thus increasing flow capacity. Advanced fracturing methods include massive hydraulic fracturing, foam fracturing, and chemical explosive fracturing.

Hydraulic fracturing, in use since the late 1940's, involves injecting a fluid under pressure into the formation, thus inducing fracturing (Riedel et a1. 1980). The fluid must be pumped out prior to gas production. A proppant, such as sand or glass beads, is entrained in the fracture fluid and remains in the formation to prop open the fractures when the fluid is withdrawn. Fracture fluids are usually water-based, but several chemicals may be added to amend the fluid (Riedel et al. 1980). Massive hydraulic fracturing is the term generally used to refer to hydraulic fracturing operations that use large volumes of fracture fluid. A typical massive hydraulic fracturing operation may inject over $1000 \mathrm{~m}^{3}(300,000$ gal $)$ of water and $500 \mathrm{Mg}\left(1 \times 10^{6} \mathrm{lb}\right)$ of sand or other proppant (Riedel et a1. 1980, 
U.S. DOE 1979a). The resulting fractures may be over $30 \mathrm{~m}$ (100ft) high and extend $300 \mathrm{~m}$ (100ft) horizontally from the well bore. Massive hydraulic fracturing requires facilities for sand and water storage, blending tanks, and pumping units.

Foam fracturing is essentially the same technique as hydraulic fracturing. Compressed gas and a surfactant, or foaming agent, are added to the fracture fluid and injected under pressure. The foam creates additional pressure for fracturing. Foam fracturing has the advantage of using less water and taking a shorter time for well cleanout than hydraulic fracturing (Riedel et al. 1980).

Chemical explosive fracturing may involve one of two approaches. Borehole "shooting," which is currently used in Devonian gas shale wells, involves detonation of nitroglycerin within the well bore to increase well bore size and induce small fractures (Kuuskraa et al. 1978, Pulle et a1. 1981). More advanced chemical explosive fracturing involves pumping a chemical slurry into existing natural fractures (or previously created hydraulic fractures) and subsequently detonating it (U.S. DOE 1979a). No proppant is injected, as the detonation generates its own proppant from formation rubble (Riedel et al. 1980).

\subsubsection{We1l Testing}

Al1 wells are generally tested for varying periods after completion of reservoir stimulation to evaluate the production capacity and success of fracturing. Usually gas produced during testing is flared on the site. Gas volumes will vary depending on the resource and well success. Testing may last a few days to a few weeks. Geopressure wells are tested for fluid flow as well as methane content. Large volumes of geopressured brines are produced during flow testing and their disposal will probably be by injection. Methane separated from the brines during testing will probably be flared. On completion of testing, any wells not used for commercial gas production are plugged and abandoned according to state-mandated procedures. 


\subsubsection{Gas Production}

Commercial production activities related to the development of unconventional gas sources will be essentially the same as those for normal commercial gas production. The produced gas may contain some fluids (probably water) and require field separation into the gas and liquid phases. The produced fluid requires disposal. Compressors may be needed to transmit the gas from the wellhead to the separators and pipeline system. The size and number of compressors required will depend on specific reservoir characteristics. If the produced gas contains large concentrations of hydrogen sulfide, desulfurization may be needed. Gas pipelines will link the production and market areas. Existing pipeline systems will be used whenever possible; however, several unconventional gas resource areas are far removed from current gas-producing regions and are not served by pipelines. Large-scale commercial production in these areas may require construction of new pipeline rights-of-way.

An alternative method for getting gas to market in areas not served by pipelines is to liquify the gas for transportation to markets. Liquefaction may be achieved by adiabatic expansion or multistage mechanical refrigeration (Bastress 1978, University of Oklahoma 1975). A portion of the produced gas is used to fuel the liquefaction plant. The energy required for liquefaction may represent up to $20 \%$ of the energy in the produced gas (University of Oklahoma 1975).

\subsubsection{Tight Gas Sands}

The depths of tight gas wells vary from basin to basin but are usually less than $3000 \mathrm{~m}(10,000 \mathrm{ft})$, except for those in the Green River Basin of Wyoming and Colorado and the cotton Valley Trend in east Texas, which may be as deep as $3800 \mathrm{~m}(12,000 \mathrm{ft}$ ) (Riedel et al. 1980). Production well spacing is at approximately $1.5-\mathrm{km}$ (1-mile) intervals (Riedel et al. 1980). Massive hydraulic and foam fracturing are the usual fracturing techniques used. In many tight gas basins, the permeable sand strata contain large volumes of connate water, which may inhibit gas production until removed. In some cases it may take 
from 3 to 6 months to sweep the water from the well (Kuuskraa et al. 1978). Disposal of the produced water is generally by surface evaporation. The stages in recovery of gas from tight western gas sands are as follows: (1) drill production well; (2) fracture formation; (3) clean fracture fluids from well and test gas production; (4) install water separators, gas clean-up equipment, and compressors as necessary; and (5) transfer product gas to collection pipelines.

\subsubsection{Devonian Gas Shales}

Well depths for shale wells are mostly less than $2200 \mathrm{~m}$ $(7000 \mathrm{ft})$ (Pulle et al. 1981). Current drilling practices make frequent use of directional drilling to intercept natural fracture systems. The most commonly used method of well stimulation is "shooting" with nitroglycerin charges (Kuuskraa et al. 1978). Several shale development projects recently used hydraulic and foam fracturing for reservoir stimulation. The stages in gas recovery from Devonian shales are the same as those for western tight sands.

\subsubsection{Coal Seam Methane}

Methane recovery from coal seams is in the developmental stage; there are currently no commercial projects. Methane may be recovered from minable or unminable coal deposits. Recovery from unminable deposits will be essentially similar to recovery from Devonian shales or western tight gas sands. Methane recovery from minable coal seams may occur by several methods before or during mining.

Recovery techniques used before mining include small-diameter vertical or directional boreholes drilled into the coal seams from the surface and horizontal boreholes drilled into the coal seams from the bottom of vertical shafts (Ethridge et al. 1980). To drain all the methane effectively, these techniques must be applied 3 to 5 years prior to mining (Ethridge et al. 1980). Gas flows from vertical wells are low. These wells may be stimulated by hydraulic or foam fracturing, but there are some concerns related to mine roof stability where fracturing is employed (Ethridge et a1. 1980). Directionally 
drilled wells that follow the coal seam produce much better gas flow rates than do vertical wells, but the thin coal seams (average thickness of 1 to $2 \mathrm{~m}$ ) present a difficult drilling target (Ethridge et a1. 1980). Horizontal holes drilled into the coal seam from shafts which are drilled from the surface to the coal seam provide favorable gas flow rates. The shafts may later be used during mining for ventilation (Ethridge et al. 1980).

Gas can be produced from working mines by drilling a series of small horizontal boreholes into the active working face of the mine. Vertical boreholes may also be drilled into the "gob" area, the strata above the coal, ahead of mining. As the area is mined, methane is released into this waste strata and drawn off by the wells.

Methane produced from the coal seams is of pipeline quality, but "gob" gas may have high concentrations of inert gases and require upgrading. Product gas may be used to produce heat or generate power for mining equipment, injected into pipelines, liquified, or used to produce ammonia or methanol (Ethridge et a1. 1980, Bastress 1978). In many cases, wells drilled into coal seams produce varying quantities of water which must be treated before disposal.

\subsubsection{Methane from Geopressured Aquifers}

Production of energy and methane from geopressured aquifers remains in the early developmental stage. Techniques for drilling and brine production are described in U.S. ERDA (1977a) and by Usibelli et al. (1980). Briefly, a production well is drilled to the geopressured zone, and hot pressurized brine is produced. The brine is "flashed" to atmospheric pressure to produce steam for electrical generation and to separate the methane gas. Recent test results indicate brine temperatures of 120 to $150^{\circ} \mathrm{C}\left(250\right.$ to $\left.300^{\circ} \mathrm{F}\right)$, salinities between 10,000 and $275,000 \mathrm{mg} / \mathrm{L}$ and methane contents below $4.5 \mathrm{~m}^{3} / \mathrm{m}^{3}$ of brine (25 scf/bbl) (Samuels 1980, McCoy et al. 1980, Dobson et al. 1980, Geoenergy Corp 1980). The brine flow from a single production well may be on the order of $2000 \mathrm{~m}^{3} / \mathrm{d}(13,000 \mathrm{bbl} / \mathrm{d})$. The most likely method for disposal of the brine is injection into saline aquifers above the 
geopressured zone. From one to four injection wells may be required to dispose of the brine from a single production well (U.S. ERDA 1977a).

\subsection{POTENTIALLY SIGNIFICANT ISSUES}

With the possible exception of recovery of methane from geopressured aquifers, unconventional gas recovery projects should not have the potential to cause major or long-term environmental impacts. The primary impacts associated with most unconventional gas recovery projects are related to land disturbance, water consumption, and short-term air quality degradation caused by site preparation, drilling, and reservoir stimulation activities. There is a potential for contamination of surface and groundwaters during drilling and formation fracturing and, where applicable, from disposal of produced formation waters. The majority of impacts associated with unconventional gas projects will occur during the initial project phases of drilling, reservoir stimulation and well testing. The time interval over which these activities will take place is generally 3 to 6 months, and is short relative to the 20- or 30-year life of a production well. Geopressure projects have a greater potential for environmental impacts than other unconventional gas projects because they will involve disposal of large quantities of low quality brines and, in many cases, may be located in wetlands. Aside from impacts directly related to unconventional gas recovery, extensive new major gas supply pipelines may be constructed to serve new resource regions and could, therefore, affect large areas of land distant from the actual project sites. The following sections discuss significant issues which are most likely to be associated with unconventional gas projects.

\subsubsection{Land Use}

Land disturbance at an unconventional gas project site is minimal compared to many other energy technologies and is limited to site preparation of drill pads, equipment lay-down areas, and access roads. The degree of disturbance connected with site preparation will depend 
on the terrain of the site; minimum disturbance may be expected in the relatively flat western tight gas basins and maximum disturbance in steep Appalachian Devonian shale and coal resource regions (Aerospace 1981). Much of the land disturbed in the early phases of the project will be restored and revegetated after drilling and fracturing are completed. The greatest potential for land-use conflicts will be associated with geopressure projects, many of which will be located in coastal wetlands, where extensive diking and dredging may be required for access, site preparation, and construction of spill containment areas. Also, several geopressure resource areas contain valuable agricultural land.

Many unconventional gas resource regions are not close to major gas supply pipelines. Development of these areas may require construction of hundreds of kilometers of large-diameter gas pipelines and many more kilometers of smaller product-gathering lines. The land-use impacts of construction of the new pipelines will far exceed the impacts related to the unconventional gas projects themselves. A recent estimate reported by Aerospace (1981) indicated that over $5000 \mathrm{~km}$ (3100 miles) of major gas pipelines may be required for extensive commercial development of unconventional gas resources. The impacts of construction of these pipelines will be common to all major pipelines. Up to 1.5 ha of land is disturbed by construction of each kilometer of major pipeline (6 acres/mile), and the 15-m (50-ft) right-of-way is kept clear of trees and shrubs after pipeline burial (Aerospace 1981). All but low intensity land uses may be prohibited within the right-of-way.

For the project site and the surrounding area, baseline information should describe:

present and planned land use;

present and projected land ownership;

national parks, national monuments, recreation areas, existing or proposed wilderness areas, and scenic, historic, or archaeologic sites or landmarks; 
Indian-owned lands and areas sacred to local Indian tribes;

- the existence of wetlands and 100-year floodplains in relation to the project; and

- location of prime or unique agricultural lands.

This baseline information should be reviewed to determine if the project may create any land-use conflicts which should be analyzed as potentially significant issues. Particularly for geopressured projects, the analysis should indicate whether any floodplains or wetlands will be affected by the project. Where appropriate, coordination with the planning agency responsible for coastal resource management should be provided. An analysis of effects on any prime or unique farmland should be provided. Visibility of the project site from any public use areas or Indian sacred areas should be analyzed. A map should be included to show surrounding land uses and potential routes for heavy equipment and other traffic associated with the project. The possibility of adverse effects from increased traffic on roads through sensitive land-use areas (e.g., Indian lands or recreation areas) should be addressed. Additionally, if the project will require construction of new gas supply pipeline rights-of-way, the analysis should state approximately how many kilometers of pipeline will be constructed, indicate the probable location of the pipelines, and discuss impacts of the pipelines on land uses along the route.

\subsubsection{Induced Seismicity and Subsidence}

Two types of geologically related impacts, induced seismicity and subsidence, may be issues for some unconventional gas projects. They are most likely to be associated with geopressured methane projects, which involve long-term withdrawal and injection of large volumes of fluid. Although seismic events have been demonstrated to result from deep injection of large volumes of fluid under high pressure in Colorado (Evans 1976, Raleigh 1971), the volumes of fluids injected during massive hydraulic fracturing are one to three orders of 
magnitude less than those that triggered the seismic events. Because costs are high, injection of geopressured brines is unlikely to occur at high pressures (Usibelli et al. 1980). Seismicity may also be induced by withdrawal of large volumes of fluids, triggering a sudden release of stress along nearby faults (Aerospace 1981). Only geopressured methane projects will involve long-term withdrawal of large fluid volumes. The Gulf coast area is aseismic (Algermissen 1968), but the possibility of induced seismicity along some of the existing growth faults in the area cannot be completely ruled out.

Subsidence has been demonstrated to be caused by withdrawal of fluids in several regions of the world, including withdrawal of geothermal fluid at Wairakei, New Zealand, groundwater in the Houston area, and hydrocarbons at Wilmington, California (Viets et al. 1979, Usibelli et al. 1980). Subsidence could occur at any unconventional gas project that withdraws large volumes of gas, but it is most likely to occur at geopressured projects where thousands of cubic meters of brine may be withdrawn each day. Both natural and man-caused subsidence is already occurring in the Gulf area and may be accelerated by project activities in areas surrounding geopressure projects.

Subsidence in the areas of low relief in the Gulf coast region could cause significant environmental damage by altering drainage patterns, reversing flow regimes in estuaries, causing intrusion of saltwater into freshwater systems, and increasing the possibility and extent of flooding during severe storms and hurricanes (Usibelli et al. 1980). Subsidence can also cause damage to man-made structures (Viets et a1. 1979). Many geopressure research projects that are currently planned or in operation include monitoring networks to detect subsidence resulting from project operations.

For all projects, but especially for geopressured projects, the analysis should include:

- an estimate of the volume of fluid expected to be withdrawn from the production well(s);

- an estimate of the volume of fluid to be injected at each injection well and the expected pressure of injection; 
- the location of major faults in the project area and an analysis of the likelihood of project operations causing induced seismicity along these faults;

- an analysis of the probability and magnitude of subsidence that might be caused by project operations, and an estimate of the impact of such subsidence on local ecosystems or man-made structures; and

- a description of existing seismic and subsidence monitoring networks of any planned seismic or subsidence monitoring planned that is part of the proposed project.

\subsubsection{Air Quality}

Impacts on air quality from most unconventional gas projects should be localized and primarily confined to the initial 3- to 6-month time interval of site preparation, drilling, reservoir stimulation, and well testing. The major atmospheric pollutants will be fugitive dust from disturbed areas, exhaust emissions from diesel engines, and emissions from flaring of produced gas that may occur during well test activities. Of the three sources, emissions from the large [7500 to $11,000 \mathrm{~W}$ (1000 to $1500 \mathrm{hp}$ )] diesel engines used to power the drill rig, the pumps, and the compressors necessary for fracturing operations will be the largest source of pollutants. The exhaust emissions will contain sulfur oxides, nitrogen oxides, particulates, hydrocarbons, carbon monoxide, and aldehydes. Operation of the several large diesel engines required for massive hydraulic fracturing may exceed ambient standards for some of these pollutants within a radius of a few kilometers of the project site for the few weeks duration of the fracturing operation (Riedel et al. 1980).

During project operations, possible sources of atmospheric pollutants would be limited to emissions from equipment such as compressors and pumps that may be required to process the gas. The characteristics and quantity of these emissions will depend on whether the equipment is powered by electricity, product gas, or diesel fuel. If $\mathrm{H}_{2} \mathrm{~S}$ removal from the product gas is required, there may also be sulfur emissions from the treatment facility. 
In addition to background information, the following information should be described and discussed:

- anticipated measures to be used for control of fugitive dust emissions;

- the number of diesel engines to be used during drilling and reservoir stimulation activities, an estimate of the emissions from the engines, and descriptions of the emission controls used on the engines;

- an analysis of the potential for the diesel emissions or fugitive dust from site preparation to cause ambient air quality standards to be exceeded, with particular reference to any Class I areas which may be affected; and

- a description of atmospheric emissions anticipated during project operations from any gas-handling and gas-cleaning equipment to be used and a description of the effect of these emissions on surrounding air quality.

\subsubsection{Water Use}

Drilling and reservoir fracturing at unconventional gas projects are water-intensive operations. Well drilling may require from 750 to $2250 \mathrm{~m}^{3}(0.5$ to 2 acre- $\mathrm{ft}$ ) of water over a $30-$ to $45-\mathrm{d}$ interval (U.S. ERDA 1977b, Aerospace 1981). Massive hydraulic fracturing can require up to $2000 \mathrm{~m}^{3}(500,000 \mathrm{gal})$ of water over a 1-week period (Riedel et a1. 1980). Availability of water for unconventional gas projects is expected to be a significant issue only in the case of western tight gas projects that will be located in arid regions of the West. A recent study reported in Riedel et al. (1980) indicated that extensive commercial development of western tight gas sands may require between $1 \times 10^{6}$ and $2 \times 10^{6} \mathrm{~m}^{3}$ (800 and 1600 acre-ft) of water per year. The water used in drilling and fracturing must be relatively low in dissolved salts to prevent adverse reactions with clays that might result in swelling and lowered production rates (Riedel et al. 1980). Groundwater in many of the western basins is too saline for use and local surface waters may have insufficient flows to provide for all water requirements at a tight gas project (Riedel et al. 1980). 
Abundant water of sufficient quality should be available in the eastern Devonian shale and coal resource areas and in the geopressured regions of the Gulf coast.

The analysis should include the following, particularly for tight gas projects:

- best estimates of quantities of water required for various project operations, and sources of water available for project development;

- for projects using groundwater resources, evaluation of the effects on and interrelationships with surrounding groundwater uses; and

- for projects using surface water resources, documentation of the availability of adequate water rights or entitlements, quantification of available yields from surface water sources, and potential adverse impacts to downstream water users.

\subsubsection{Water Quality}

Unconventional gas projects can affect water quality by release of sediments from land disturbed by site preparation, by accidental release of drilling muds or fracturing fluids into surface or ground waters, or by accidental release or routine disposal of produced formation waters. For most unconventional gas projects, sedimentation from site preparation may be the largest routine source of water quality degradation. The potential for erosion and sedimentation will be the greatest for Devonian shale and coal-bed methane projects in the steep areas of Appalachia, and the least for tight gas projects in the arid West. Site preparation at some geopressure projects may require dredging in freshwater and coastal wetlands, which will cause localized increases in suspended sediments and could mobilize toxic pesticides, herbicides, and heavy metals that have accumulated in bottom sediment.

Accidental release of drilling muds and fracturing fluids could degrade surface and groundwater quality. Constituents present in drilling muds and fracturing fluids will vary according to the requirements of each project. Simple drilling muds usually contain 
only bentonite clays and possibly caustic soda, but some potentially toxic chemicals may be added to the muds (Aerospace 1981, MITRE 1981). Likewise, simple hydraulic fracturing fluids may contain primarily potassium chloride, but complex fluids may contain metal-based foaming agents, petroleum condensates, sulfonates, electrolytes, and acids (Aerospace 1981). Chemical explosive fracturing fluids may contain nitrate-based explosives and several other chemicals. Drilling muds could enter near-surface aquifers by seepage from unlined reserve pits. Fracturing fluids, which may be injected at pressures in excess of $80 \mathrm{MPa}(12,000 \mathrm{psi})$, could potentially migrate to potable aquifers from improperly cased wells or unsuspected fractures connecting the target formation with the aquifer (Aerospace 1981). Spills of drilling muds and fracturing fluids on the order of several cubic meters could be possible from overflow of reserve pits or holding tanks or rupture of surface piping.

Many unconventional gas projects will involve production of varying amounts of water present in the gas-bearing formation. Water produced from tight gas formations may be high in dissolved salts and may possibly contain some hydrocarbon residuals. Water produced from eastern coal seams may be alkaline or acidic and may contain dissolved salts ranging in concentration from about $1,000 \mathrm{mg} / \mathrm{L}$ to $150,000 \mathrm{mg} / \mathrm{L}$ (Ethridge et al. 1980). Disposal alternatives for produced water range from surface evaporation in the western tight gas basins to treatment and disposal into surface waters in much of the eastern shale and coal resource areas.

Disposal and handling of geopressured brines will be the most significant issue associated with geopressured methane projects, not only because of the enormous quantity of brines involved, but because many of the projects are likely to be located near economically and ecologically important wetlands. One geopressure well may produce between 1600 and $6000 \mathrm{~m}^{3}(10,000$ and 50,000 bbl) of brine each day, or between $12 \times 10^{6}$ and $60 \times 10^{6} \mathrm{~m}^{3}(10,000$ and 50,000 acre-ft) of brine over a 20-year operating lifetime (Usibelli et al. 1980). Several production wells may be located at one project. Potential 
impacts to surface waters will depend on the volume of brine that may be released to surface systems and on the thermal and chemical characteristics of the brines. The temperature of geopressured brines may range between 120 and $150^{\circ} \mathrm{C}\left(250\right.$ and $\left.300^{\circ} \mathrm{F}\right)$. The brines may exhibit salinities ranging from 10,000 to $275,000 \mathrm{mg} / \mathrm{L}$ and may contain environmentally damaging concentrations of boron, ammonia, fluorides, chlorides, iron, zinc, lead, and possibly other heavy metals (Usibelli et al. 1980, U.S. DOE 1981).

At most geopressure projects, the brines will not enter surface waters during normal operations. The most likely disposal method will be injection into saline aquifers above the geopressured zone (Usibelli et a1. 1980). During emergency or upset conditions, such as those that might result from a well blowout or major pipe rupture, however, geopressured brines could enter surface waters. About $16,000 \mathrm{~m}^{3}$ $(100,000 \mathrm{bbl})$ of fluid might be released due to a pipe rupture, and over $80,000 \mathrm{~m}^{3}(500,000 \mathrm{bb} 1)$ might be released within a few days during a well blowout (Usibelli et al. 1980). Because pressures are high and significant quantities of gas are present, well blowouts at geopressured wells are more likely to occur than at other types of wells (U.S. ERDA 1977a, Rehm and Goins 1978). Mitigation of accidental release of geopressured brines is best achieved with adequate blowout control and a spill control and counter-measure program.

The analysis should contain information about ambient water quality for all ground and surface water systems which may be affected by project activities. Applicable water quality standards should also be included. To address potential effects on water quality adequately, the following information should be provided for all unconventional gas projects:

an estimate of the amount of erosion and sedimentation that may occur as a result of site preparation and pipeline construction and an analysis of effects on local water quality;

- a description of erosion and sedimentation control measures; 
- a description of any dredging anticipated and an analysis of effects on local water quality;

- a description of constituents expected to be present in drilling muds and in formation fracturing fluids; and

- descriptions of the methods that will be used to ensure that these materials will not enter surface or groundwaters, including details about construction and lining of reserve pits and holding ponds, and any diking around well pads to contain spills and runoff.

For other than geopressured projects the following information should be provided:

- an estimate of the amount and chemical composition (if known) of any formation water that may be produced along with the product gas and, if possible, an estimate of the time interval over which these waters may be produced; and

- a description of the disposal alternatives being considered for the produced water, with an analysis of potential effects on surface and groundwater systems from this disposal.

For geopressured projects specifically, the following information should be provided:

- a description of the expected chemical constituents and their concentrations in the brines, and an estimate of the surface brine temperature;

- an estimate of the amount of brine that may be produced daily during normal operations and the anticipated disposal method;

- information about the water quality of the receiving aquifer and the anticipated depth, pressure, and rate of injection wells required for each production well, if disposal will be by injection,;

- worst-case estimates of the volume of brines which may be released to surface waters during upset conditions, including a major pipe rupture, failure of a holding pond, and a well blowout; 
- an analysis of effects on water quality of the receiving system from the accidental releases described above; and

- a detailed spill control and countermeasure plan including clean-up methods in the event of an accidental release of brines.

For all projects, a list of all surface discharge or injection permits should also be provided, along with applicable water quality limitations. Information about anticipated surface and groundwater monitoring programs before and after project operations should be included.

\subsubsection{Impacts on Biota}

Unconventional gas projects will disturb some terrestrial wildilfe habitat, but the amount of habitat that will be affected will be small compared to that disturbed by other energy technologies involving mining and construction of large permanent facilities. Tight gas and geopressured methane projects are those most likely to affect valuable wildlife habitat. The western tight gas basins contain several wildlife species that are sensitive to human presence and could be adversely affected by the noise levels and increased human activity associated with gas recovery. Geopressured methane projects could directly or indirectly affect important wildiife habitat in freshwater, brackish, and saltwater marshes of the Guif Coast area.

Potential impacts on aquatic biota may result from point or non-point effluents from unconventional gas projects. Increased erosion and sedimentation may result in elevated suspended solids concentrations, thereby adversely affecting aquatic biota. Consumptive water withdrawals may alter instream habitat conditions. Dredging at geopressure projects may alter aquatic habitats, increase suspended solids, and mobilize toxic materials that have accumulated in the bottom sediments. Drilling muds, fracturing fluids, formation waters, or geopressured brines may be released into surface waters during normal operations or as a result of an accident. These materials could 
contain a variety of potentially toxic substances in currently unknown concentrations that could adversely affect aquatic biota downstream of the release.

Using general baseline information on the affected environment, onsite inventory data (the type and extent determined during early consultation), and the project description, the environmental analysis should:

- describe the terrestrial and aquatic habitats that will be disturbed by all project activities, with special attention to habitat for any endangered, threatened, rare, or otherwise protected plant and animal species;

- estimate the number of hectares of each type of habitat that will be disturbed by project activities;

- present a reclamation plan for all disturbed areas, along with an evaluation of the likely success of reclamation;

- provide information about the constituents and their concentrations in drilling muds, fracturing fluids, formation waters, and geopressured brines, and, where possible, evaluate the toxicity of these constituents to target species of aquatic biota; and

- include information from initial contacts with state and federal fish and wildife agencies and conservation personnel (formal consultation with the U.S. Fish and Wildlife Service in relation to the status of federally listed threatened and endangered species is the responsibility of the federal action agency).

In addition to effects on biota from activities directly related to the unconventional gas project, construction of new major gas supply pipelines could affect hundreds of hectares of wildlife habitat far removed from the project site. If construction of significant new pipelines will be directly associated with the project, the following information should be provided:

- a description of the terrestrial and aquatic habitats that might be affected by pipeline construction, paying particular attention to habitat for rare, endangered, threatened, or otherwise protected plant and animal species; 
an estimate of the potential effect on these habitats from pipeline construction; and

- a reclamation and management plan for the pipeline corridor, including the method and frequency of removal of trees and shrubby vegetation from the pipeline right-of-way.

\subsubsection{Noise}

During the initial 3- to 6-month period of project activities, high noise levels will be associated with drilling and operation of large diesel engines during site preparation and formation fracturing. During this time noise levels from drilling may be about 85 to $90 \mathrm{~dB}(\mathrm{~A})$ at $15 \mathrm{~m}(50 \mathrm{ft})$ from the well, attenuating to 50 to $55 \mathrm{~dB}(\mathrm{~A})$ at $800 \mathrm{~m}$, and noise levels from large diesel engines may be in excess of $100 \mathrm{~dB}(A)$ at $15 \mathrm{~m}(50 \mathrm{ft})$, attenuating to over $65 \mathrm{~dB}(A)$ at $800 \mathrm{~m}(0.5$ mile) from the project site (U.S. DOE 1979b, Riedel et al. 1980). Noise could be a worker health and safety issue (Section 6.3.9) and would become an environmental issue in cases where the project may be located near residences, public use areas, wilderness areas, or habitat for sensitive wildlife species. Estimates of the level of noise produced by project activities should be supplied. Details about noise control measures should be supplied where appropriate. Information on the level of sensitivity and the distance to nearby sensitive receptors (e.g., recreational areas, backpacking trails, or residential areas) should also be provided.

\subsubsection{Socioeconomics}

Unconventional gas projects are not expected to create significant adverse socioeconomic impacts because they will not involve in-migration of a large work force. The largest work force will be present during drilling and fracturing operations and will consist of about 25 people for each well. These workers in most cases will not be from the local areas, as they are usually supplied by the contracting companies that specialize in drilling services. Most of these workers are likely to be housed in motels or rental housing. They may create some strain on 
the availability of such housing at projects located in areas remote from larger communities, but the work force should be not so large nor the duration of their stay so long as to create any adverse "boomtown" effects. The operational work force at most unconventional gas projects will be smaller than that present during drilling and will probably be drawn from the local population.

To address socioeconomic considerations for all types of unconventional gas projects, the following information should be provided:

- the number of workers expected to be involved in each phase of project activity, and an estimate of what percentage of them are expected to be nonlocal;

- plans for providing housing for the workers; and

- a determination of the adequacy of housing supply, municipal and community services, and transportation networks in these communities to support the in-migrating workers.

\subsubsection{Health and Safety}

The health and safety issues related to most aspects of unconventional gas technology are identical to those associated with conventional gas well drilling and production. Additionally, health and safety issues related to geopressure projects will be identical to those associated with geothermal drilling and operating technology. A summary of the issues follows:

- mechanical injury from setting casing, adding and removing drill string, rig assembly, and maintenance and equipment failure;

- exposure to significant noise levels during drilling, pumping operations, and venting of gas and fluids (MITRE 1981);

- exposure to high concentrations of exhaust emissions (particularly carbon monoxide) from diesel machinery used to power dri11 rig and compressors (U.S. DOE 1979a, Riedel et a1. 1980, U.S. EPA 1979, NRC 1981); 
- exposure to potentially harmful chemicals (including potential carcinogens) present in drilling muds and fracturing fluids (U.S. DOE 1979C, MITRE 1981);

- potential hazard associated with accidental mixing or improper handling aboveground of chemical explosive slurry used in chemical explosive fracturing operations (U.S. DOE 1979a);

- exposure to radiation from gamma emitter (192Ir) added to fracturing sand (Riedel et a1. 1980; ICRP 1959);

- occurrence of well blowouts, which could result in fire or uncontrolled release of large quantities of hot fluid in geopressure wells (the combination of dissolved gas and high pressures increase the potential for blowouts in geopressure projects); and

- for geopressure projects, the hazards of handling large quantities of hot and chemically complex brines that may contain high concentrations of ammonia, boron, and trace metals (the pressures involved with geopressure operation increase the potential for spills due to pipe rupture or other equipment failure).

The issues described above should be evaluated in detail appropriate to the type and scope of the unconventional gas project under consideration. Additionally, an environmental analysis should present plans for monitoring worker environments, accomplishing regular maintenance and inspections of all equipment and facilities, and use of protective clothing and equipment as necessary. Plans should be developed for compliance with existing National Institute for Occupational Health and Safety and Occupational Safety and Health Administration regulations, as appropriate.

There are some unique safety concerns related to projects involving methane from minable coal seams. Mine operators are concerned that fracturing operations to increase gas flow may damage the overlying rock strata that comprise the roof of the mine, thereby increasing the potential for cave-ins. Mining into a degasification borehole can suddenly release large quantities of methane that may have accumulated in the borehole following gas recovery operations. This methane 
released into the mine could create a potentially explosive atmosphere (Ethridge et al. 1980). Also, there is considerable resistance from mine operators and miners to methane recovery in an active mine because of the potential for accidental release of large quantities of gas into the mine from equipment or pipeline failure (Ethridge et al. 1980). These potential hazards should be addressed for projects recovering methane from minable coal, and the methods to be used to ensure mine safety should be described in detail. 


\subsection{REFERENCES}

Aerospace. 1981. Energy Technologies and the Environment. DOE/EP0026. Prepared for Assistant Secretary for Environmental Protection, Safety and Emergency Preparedness. U.S. Department of Energy, Washington, D.C.

Algermissen, S. T. 1968. Seismic Risk Map of the United States. U.S. Government Printing Office, Washington, D.C.

Bastress, E. K. 1978. Utilization options for coalbed methane. pp. 108-119. IN Methane Gas from Coalbeds. MERC/SP-78-1. U.S. Department of Energy, Washington, D.C.

Dobson, R. J., V. A. Hartsock, R. L. McCoy, and J. A. Rodgers. 1980. Investigation and evaluation of geopressured-geothermal wells: Final report, Beulah Simon No. 2 Well, Vermilion Parish, Louisiana. DOE/ET/28460-3 (Vol. 2). U.S. Department of Energy, Washington, D.C.

Energy Information Administration (EIA). 1981. Monthly energy review September 1981. DOE/EIA-0035(81/09). U.S. Department of Energy, Washington, D.C.

Ethridge, L. J., C. E. Cowan, and E. F. Riedel. 1980. An assessment of environmental health and safety issues sssociated with the commercialization of unconventional gas recovery: Methane from coal seams. PNL-3413. Pacific Northwest Laboratory, Richland, Washington.

Evans, D. M. 1976. Man-made earthquakes in Denver. Geotimes 10:11-18.

GeoEnergy Corporation. 1980. Minutes from DOE/Industry Geopressured Geothermal Resource Development Program Working Group Meetings. Prepared for U.S. Department of Energy by GeoEnergy Corporation, Las Vegas, Nevada.

International Commission on Radiological Protection (ICRP). 1959. Recommendations of the International Commission on Radiological Protection. ICRP Publ. 1. Pergamon Press, London.

Jones, P. H. 1976. Natural gas resources of the geopressured zones in the northern Gulf of Mexico basin. pp. 17-33. IN Natural Gas from Unconventional Geologic Sources. National Academy of Sciences, Washington, D.C.

Kuuskraa, V. A. 1981. Unconventional gas -- Summary of an ORNL technical seminar. ORNL/PPA-81/5. Oak Ridge National Laboratory, Oak Ridge, Tennessee. 
Kuuskraa, V. A., J. P. Brashear, T. M. Doscher and L. E. Elkins. 1978. Enhanced recovery of unconventional gas. HCP/T2705-02. Prepared by Lewin \& Associates for the U.S. Department of Energy, Washington, D.C.

MITRE. 1981. Health and environmental effects of oil and gas technologies: Research needs. MTR-81W77. Prepared for the Federal Interagency Committee on the Health and Environmental Effects of Energy Technologies by the MITRE Corporation, McLean, Virginia.

McCoy, R. L., J. H. Hartsock, and R. J. Dobson. 1980. Preliminary results of the wells-of-opportunity geopressured-geothermal testing program. pp. 289-295. IN Proc., First Annual Symposium on Unconventional GaS Recovery. SPE/DOE-8958. American Institute of Mining Engineers, Dallas, Texas.

National Petroleum Council (NPC). 1980. Unconventional gas sources, Executive summary. DOE-TIC-11417. National Petroleum Council Committee on Unconventional Gas, Washington, D.C.

National Research Council (NRC). 1981. Health Effects of Exposure to Diesel Exhaust. National Academy Press, Washington, D.C.

Papadopulos, S. S., R. H. Wallace, Jr., J. B. Wesselman, and R. E. Taylor. 1975. Assessment of onshore geopressured-geothermal resources in the northern Gulf of Mexico basin. pp. 125-46. IN D. White and D. L. Williams (eds.), Assessment of Geothermal Resources of the United States - 1975. U.S. Geol. Surv. Circ. 726.

Pulle, C. V., A. P. Seskus and A. Komar. 1981. Economically recoverable gas from Devonian Shales in the Appalachian Basin. pp. 313-322. IN Second International Gas Research Conference. Government Institutes, Inc., Rockville, Maryland.

Raleigh, C. B. 1971. Earthquake Control at Rangely, Colorado. Trans. Am. Geophys. Union 52:344-353.

Rehm, W. A. and W. C. Goins, Jr. 1978. Geothermal and geopressured blowout contro1. ID0-1603-1. Prepared by Maurer Engineering, Inc. for the U.S. Department of Energy, Washington, D.C.

Riedel, E. F., C. E. Cowan, and T. J. MCLaughlin. 1980. An assessment of environmental, health and safety issues associated with the commercialization of unconventional gas recovery: Tight western sands. PNL-3391. Prepared for the U.S. Department of Energy by Pacific Northwest Laboratory, Richland, Washington.

Samuels, G. 1980. Evaluation of the geopressured energy resource of Louisiana and Texas. pp. 215-223. IN Proc., First Annual Symposium on Unconventional Gas Recovery. SPE/DOE-8948. American Institute of Mining Engineers, Dallas, Texas. 
U.S. Department of Energy (U.S. DOE). 1979a. Environmental development plan for unconventional gas recovery. DOE/EDP-0049. Office of the Assistant Secretary for Fossil Energy and Assistant Secretary for Environment, Washington, D.C.

1979b. Environmental assessment for the Westmorland Project, Geothermal Loan Guarantee Program, Imperial County, California. DOE/EA-0058. Washington, D.C.

1979c. Environmental issues relating to fossil energy technology options. DOE/EV-0065. U.S. Government Printing office, Washington, D.C.

1980. Fossil
D0E/FE-0006. Engy Program Summary for FY 1981.
Washington, D.C.

U.S. Energy Research and Deve 1opment Administration (U.S. ERDA). 1977a. Environmental impact assessment, geopressure subprogram. EIA/GE/77-3. Division of Geothermal Energy, Washington, D.C.

1977b. Environmental impact assessment, hydrothermal subprogram. EIA/GE/77-2. Division of Geothermal Energy, Washington, D.C.

U.S. Environmental Protection Agency (U.S. EPA). 1979. Air quality criteria for carbon monoxide. EPA-600/8-79-022. Environmental Criteria and Assessment Office, Environmental Protection Agency, Research Triangle Park, North Carolina.

University of Oklahoma, Science and Public Policy Program. 1975. The Natural Gas Resource System. Chapter 4. IN Energy Alternatives: A Comparative Analysis. U.S. Government Printing office, Washington, D.C.

Usibelli, A., P. Deibler, and J. Sathaye. 1980. The geopressured geothermal resource of the Texas and Louisiana Gulf Coast: A technology characterization and environmental assessment. LBL-11539. Prepared for the U.S. Department of Energy by Lawrence Berkeley Laboratory, Berkeley, California.

Viets, V. F., C. K. Vaughan and R. C. Harding. 1979. Environmental and economic effects of subsidence. LBL-8615, GSRMP-1. Prepared for Geothermal Subsidence Research Program, Lawrence Berkeley Laboratory, Berkeley, California. 
164

$\theta$ 


\section{FUEL ETHANOL}

R. Dickinson Roop 1

\subsection{RESOURCE DESCRIPTION}

The resources available for production of fuel alcohol are quite varied and not easily quantified. Feedstocks suitable for fermentation (Table 15) include starch crops, sugar crops, cellulosic material, and some wastes. The feedstocks most readily converted to ethanol are starch crops (especially corn) and sugar crops (e.g., sugar beets). Although the quantities of such crop feedstocks which are produced are well documented (USDA 1978), the portion that might be economically available for ethanol production is dependent on many unknown factors such as the fluctuating demands for fuel and food. Table 16 gives estimates of potential ethanol production based on availability of various crops and wastes.

While processes for fermentation of cellulosic feedstocks exist, these have generally not been proven on a commercial scale. It is not known whether lignin-containing cellulosic material (e.g. forestry residues) will be suitable for fermentation. Thus, considerable speculation is involved in attempts to quantify the potential resource base of cellulosic material. The availablity of biomass feedstocks suitable for large-scale production of ethanol is considered in detail by Braunstein et al. (1981).

Land is the most basic resource affecting the availability of feedstock for ethanol production, and almost $90 \%$ of the United States' $936 \times 10^{6}$ ha produces some sort of biomass that is commercially used. Approximately $20 \%$ of the U.S. area is devoted to growing crops (SCS 1977), with the greatest area devoted to corn, wheat, hay, soybeans, sorghum grain, and oats (in order of declining importance)

TEnergy Division, ORNL. 
Table 15. Feedstock advantages and disadvantages [modified from Table IV-1, SEIDB (1980)]

\begin{tabular}{|c|c|c|c|}
\hline $\begin{array}{l}\text { Type of } \\
\text { feedstock }\end{array}$ & $\begin{array}{l}\text { Processing } \\
\text { needed before } \\
\text { fermentation }\end{array}$ & $\begin{array}{l}\text { Principal } \\
\text { advantage(s) }\end{array}$ & $\begin{array}{l}\text { Principal } \\
\text { disadvantage(s) }\end{array}$ \\
\hline $\begin{array}{l}\text { Starch crops: } \\
\text { Grains (e.g., corn, } \\
\text { wheat, sorghum, barley } \\
\text { Tubers (e.g., potatoes, } \\
\text { sweet potatoes) }\end{array}$ & $\begin{array}{l}\text { Milling, liquefaction } \\
\text { and saccharification }\end{array}$ & $\begin{array}{l}\text { 1. Storage techniques are } \\
\text { well developed } \\
\text { 2. Cultivation practices are } \\
\text { widespread except for sorghum } \\
\text { 3. Livestock feed by-product is } \\
\text { relatively high in protein }\end{array}$ & $\begin{array}{l}\text { Preparation involves } \\
\text { additional equipment, } \\
\text { labor, and energy costs }\end{array}$ \\
\hline $\begin{array}{l}\text { Sugar crops (e.g., sugar } \\
\text { beets, sweet sorghum, } \\
\text { sugarcane, fodder beet, } \\
\text { Jerusalum artichoke) }\end{array}$ & Milling to extract sugar & $\begin{array}{l}\text { 1. Preparation is minimal } \\
\text { 2. High yields of ethanol } \\
\text { per hecatre } \\
\text { 3. Crop coproducts have } \\
\text { value as fuel, livestock } \\
\text { feed or soil amendment }\end{array}$ & $\begin{array}{l}\text { 1. Difficulty of storage may limit } \\
\text { year-round use of single feedstock } \\
\text { 2. Storage may result in loss of sugar } \\
\text { 3. Cultivation practices are not wide- } \\
\text { spread, especially with "nonconven- } \\
\text { tional" crops }\end{array}$ \\
\hline $\begin{array}{l}\text { Cellulosic: } \\
\text { Crop residues (eg., } \\
\text { corn stover, wheat } \\
\text { straw } \\
\text { Forages (e.g., alfalfa, } \\
\text { Sudan grass, forage } \\
\text { sorghum }\end{array}$ & $\begin{array}{l}\text { Milling and hydrolysis } \\
\text { of the cellulose linkages }\end{array}$ & $\begin{array}{l}\text { 1. Use involves no integration } \\
\text { with the livestock feed } \\
\text { market } \\
\text { 2. Availability is widespread }\end{array}$ & $\begin{array}{l}\text { 1. No commercially cost-effective } \\
\text { process exists for hydrolysis of } \\
\text { the linkages } \\
\text { 2. Collection of diffuse materials } \\
\text { 3. Erosion from removing residues }\end{array}$ \\
\hline $\begin{array}{l}\text { wastes }(e \cdot g \text {, distressed } \\
\text { grains, cull fruits and } \\
\text { vegetables, grain dust, } \\
\text { and whey }\end{array}$ & Variable & 1. Low cost & $\begin{array}{l}\text { 1. Limited availability } \\
\text { 2. Distillers dried grain from afla- } \\
\text { toxin-contaminated grain is not } \\
\text { suitable as animal feed }\end{array}$ \\
\hline
\end{tabular}


Table 16. Biomass availability for ethanol production [million L/year (million gal/year)]

\begin{tabular}{lrrr}
\hline Biomass feedstock & $\begin{array}{c}\text { Currently } \\
\text { availablea }\end{array}$ & $\begin{array}{c}\text { Potentially } \\
\text { availableb }\end{array}$ \\
\hline Cheese whey & $341(90)$ & 341 & $(90)$ \\
Citrus waste & $795(210)$ & 795 & $(210)$ \\
Other food wastes & $568(150)$ & $568(150)$ \\
Corn & $681(180)$ & $6,280(1,660)$ \\
Grain sorghum & $114(30)$ & $1,060 \quad(280)$ \\
Sugar cane & - & $568(150)$ \\
Wheat & - & $4,280(1,130)$ \\
Municipal solid waste & - & $4,160(1,100)$ \\
Total & $2,500(660)$ & $18,050(4,700)$
\end{tabular}

a Available biomass that can be converted to ethanol with present technologies, without changing set-aside and diversion policies.

bavailable biomass if all set-aside and diverted lands (but no new or marginal lands) are brought into production and sugar surpluses and $50 \%$ municipal solid wastes are used with current technologies to make ethanol. No agricultural or wood residues or sweet sorghum potentials are included.

SOURCE: Muller Associates, Inc. 1981. 
(USDA 1978). Crop production in the United States, although most concentrated in the Midwest, is widely distributed throughout the country. Because crop feedstocks suitable for fermentation vary and crop production is widely distributed, ethanol production facilities could be located in most parts of the United States, except possibly desert or mountain areas.

\subsection{TECHNOLOGY OVERVIEW}

The technology of alcohol production from grain and sugar crops has been well established by years of experience in the beverage industry. Production of fuel alcohol, however, allows the use of a wider variety of feedstocks, because taste and absolute purity of the product are of little importance. Cellulosic feedstocks (e.g., crop residues, forage grasses, and wood) also lend themselves to alcohol production, but a commercial process for hydrolysis to produce fermentable materials from cellulosics has not yet been proven. The discussion here will focus primarily on use of sugar or starch materials because they are the most likely to be used in the near term. A brief overview of fuel alcohol production is given below as general background for persons unfamiliar with the technology. More detailed descriptions of alcohol production terminology can be found in other documents (USDA 1980, SEIDB 1980, Elmore et al. 1982).

\subsubsection{Alcohol Production Process}

Production of fuel alcohol involves the following basic steps (Fig. 12):

- feedstock preparation (e.g., milling),

- pre-treatment (e.g., cooking and enzyme digestion),

- fermentation,

- distillation,

- dehydration, and

- by-product recovery. 
ORNL DWG $80 \quad 16954 \mathrm{R}$

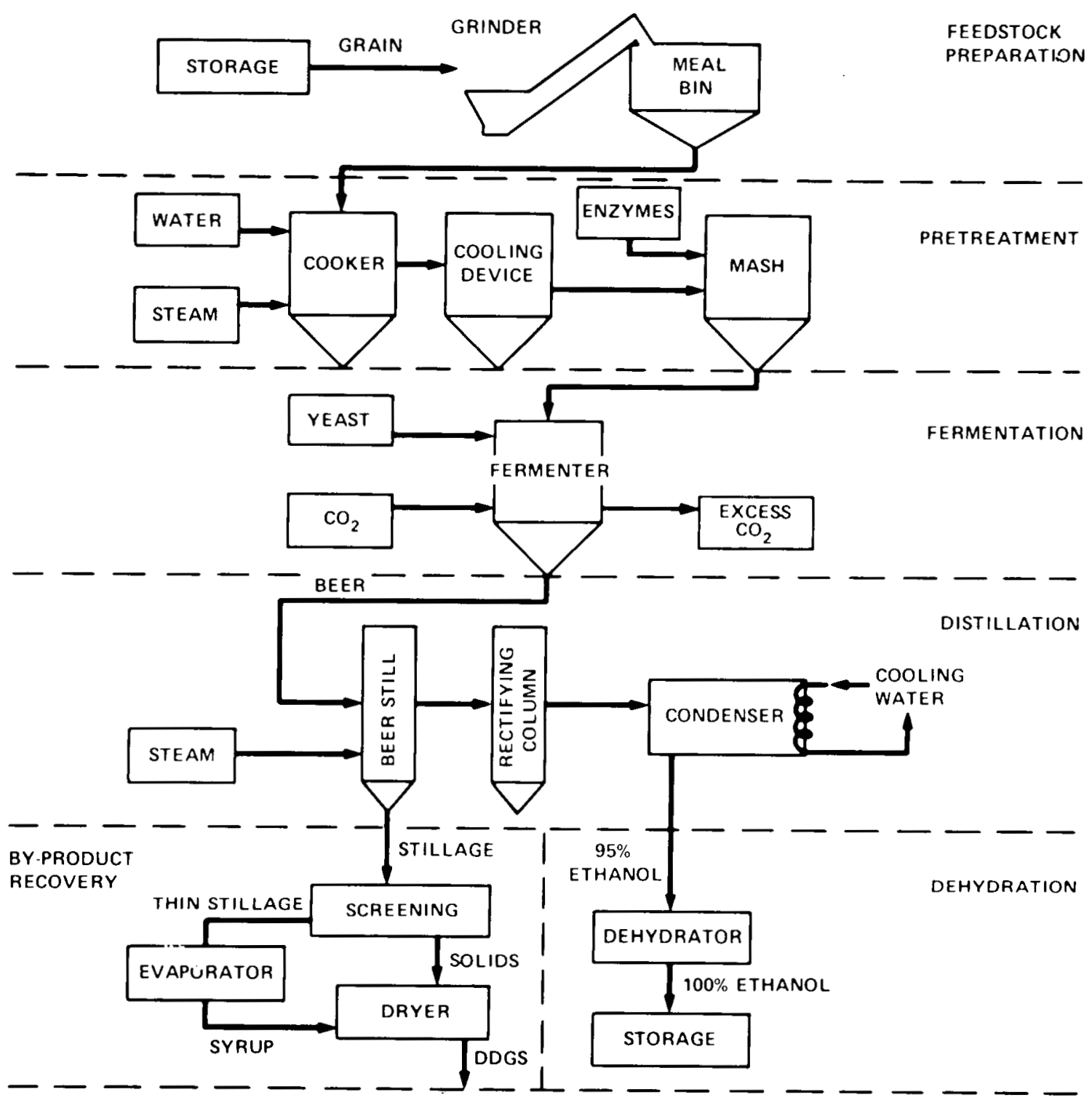

Fig. 12. Typical processing steps for conversion of grain to ethanol. 
The basic process may be modified to some extent, depending on the feedstock involved. Corn or other grains are most commonly used, although sugar crops and a variety of food processing wastes can be readily employed in existing commercial processes.

Feedstock preparation and pre-treatment produce a solution of simple sugars for fermentation. The initial steps of this process, collectively known as liquefaction, involve milling the grain, adding water to form a slurry, cooking to release starch from plant cells and to provide an optimum temperature for hydrolysis, and adding enzymes or acids that convert starch to complex sugars (dextrins). Liquefaction is followed by saccharification, the conversion of complex sugars to simple sugars such as glucose, which is accomplished by lowering the temperature, adjusting the $\mathrm{pH}$, and adding additional enzymes. The mash produced by this process is suitable for fermentation.

Fermentation, the conversion of sugars to ethanol and $\mathrm{CO}_{2}$, is carried out by yeasts of the genus Saccharomyces. To produce a maximum quantity of alcohol, the strain of yeast is carefully selected and the mash or "beer" is adjusted to optimum conditions of sugar concentration $(10$ to $22 \%), \mathrm{pH}(3.0$ to 5.0$)$, and temperature $\left(27\right.$ to $\left.32^{\circ} \mathrm{C}\right)$. The rate of fermentation varies with the sugar concentration and the initial concentration of yeast cells.

Distillation separates the ethanol from the "beer" by taking advantage of the ethanol's lower boiling temperature compared to that of water. Fermented mash is fed into a stripping column or beer still (Fig. 12) which is heated with steam. Ethanol and some water evaporate and leave the top of the column as vapor, while the remaining liquid (stillage) leaves the bottom of the column. The vapors enter a rectifying column in which counter-current flow further separates the alcohol from the water. The vapor from the rectifying column (Fig. 12) is condensed and part of the product is recycled to the top of the rectifying column. The product is an azeotropic mixture of about $95 \%$ ethanol and 5\% water. This mixture has a constant boiling temperature and cannot be separated by simple distillation. 
Dehydration of the azeotrope can be accomplished by either a tertiary distillation or use of a molecular sieve. In tertiary distillation, a third liquid (benzene, ether, gasoline, ethylene glycol, or some other solvent) is added to the azeotrope to change the boiling characteristics and allow separation of anhydrous ethanol. Molecular sieves remove the water from 190 proof alcohol by selectively adsorbing it to some material. This material then typically requires high-temperature regeneration to remove the water.

In some cases, the stillage from alcohol production can yield marketable by-products. If corn is used as the feedstock, the stillage will contain the protein originally present in the corn plus protein produced by the yeast. Unprocessed stillage (i.e., whole stillage) typically has only a 6 to $8 \%$ solids content (Anthony 1979). It can be fed directly to livestock, but it spoils very quickly and cannot be stored for more than a few days. Solids can be removed from stillage by passing it through separators or dewatering presses, yielding thin and thick stillage respectively. To recover a dried product, thin stillage is concentrated in evaporators to a syrup of $25 \%$ solids content that can then be added to the thick stillage and dried to form distillers dried grains with solubles (DDGS), having a 10 to $12 \%$ moisture content.

\subsubsection{Raw Materials}

The raw materials needed for ethanol production include feedstock, water, acids or enzymes, and yeast cultures. The feedstock for alcohol production is an important determinant of process design, facility siting, and economics. Potential conventional feedstocks include (1) sugar crops, (2) starch crops, (3) cellulosic materials, and (4) waste materials such as distressed grains, grain elevator dust, and whey from cheese manufacturing. Advantages and disadvantages of various feedstocks are summarized in Table 15.

The amount of water needed varies with the system design and may range from 50 to $240 \mathrm{~L}$ water/L ethanol (ASTM 1969). Water is used in several steps of the production process and for cooling, boiler feed 
and make-up, and washing. Relatively high quality water is required for certain steps in the production process (Mckee and Wolf 1963), including liquefaction, saccharification, and fermentation. Water that meets the drinking water standard of $500 \mathrm{mg} / \mathrm{L}$ total dissolved solids is suitable for many boilers, but in some cases water softening to remove dissolved solids may be necessary.

The enzymes and yeast cultures needed for alcohol production are typically obtained from commercial suppliers, but large or experimental ethanol production plants may include facilities for enzyme production or for culturing necessary microorganisms.

\subsubsection{Energy Sources}

In the past, natural gas and oil have been the major fuels used to fire boilers that provide process heat for cooking, fermentation, distillation, and drying of by-products. Because the major reason for developing an alcohol fuels industry is to reduce dependence on scarce and imported fuels, current developers of alcohol facilities are considering a wide range of alternative energy sources. Fuels that may be used to fire boilers include coal, wood, bagasse (processed sugarcane), crop residues, and municipal solid wastes. Another possible fuel, biogas (methane), could be produced by anaerobic digestion of manure generated in feedlot operations. Close integration of distilleries and feedlots could result in high energy efficiency. Feeding whole stillage produced in alcohol production to livestock avoids the high energy costs of drying the stillage. Also, anaerobic digestion of feedlot manure solves a disposal problem and could reduce some of the nuisance caused by feedlot odor.

Low-temperature heat is adequate for many of the process steps in ethanol production. Cooking, fermentation, and by-product drying can all be accomplished at temperatures below $100^{\circ} \mathrm{C}$. Ethanol production facilities could therefore utilize unconventional energy sources, such as geothermal energy, solar energy, or waste heat from electricity generation, petroleum refining, or other sources to meet all or part of their energy requirements. 


\subsubsection{Economic Factors}

A full discussion of the economics of ethanol production is clearly beyond the scope of this document. However, several economic issues have a direct bearing on the environment and should therefore be considered.

Two economic factors will influence the size of alcohol production facilities. Economies of scale will promote selection of larger plants. Plant sizes of $39 \times 10^{6}$ to $113 \times 10^{6}$ L/year $\left(10 \times 10^{6}\right.$ to $30 \times 10^{6}$ gal/year) are favored by many established engineering design firms in order to capture the benefits of process refinements such as continuous cooking and fermentation. In contrast, many developers will choose smaller plant sizes [e.g., $4 \times 10^{6}$ to $11 \times 10^{6}$ L/year $\left(1 \times 10^{6}\right.$ to $\left.3 \times 10^{6} \mathrm{gal} / \mathrm{year}\right)$ or smaller] to achieve integration with farm operations. Such an approach could produce cost-savings through use of locally produced feedstock and local distribution of whole stillage.

A third economic factor to be considered is the need to make the product accessible to markets. The output of smaller plants may be targeted to on-farm use, while the location of larger units will depend on location of end use, the sources of feedstock, and the availability of transportation.

The handling of stillage is vital to the economics of plant operation. For projects using corn as the feedstock, revenues from by-product sales are essential to profitable operation. Furthermore, unless stillage can be utilized in some manner, disposal costs will be incurred.

Other important economic considerations that will be of concern relate to the large volumes of water that are used and discharged and the availability of alternative energy sources for the plant (including cogeneration). Finally, market factors related to user demand and acceptance must be considered. 


\subsection{POTENTIALLY SIGNIFICANT ISSUES}

Fuel ethanol production facilities are often small in scale compared to many energy installations, and environmental impacts associated with construction and operation of such facilities are normally of limited extent. Potentially significant issues that should commonly be considered are identified and discussed in the following sections. In cases where projects include large feedstock production operations, environmental impacts associated with such production should also be addressed.

\subsubsection{Land Use}

The potential for significant land-use conflicts at a fuel ethanol production facility will depend to a large extent on the current use of the site and its immediate vicinity and on the type of operation being proposed. If the proposed facility is an expansion of an existing operation (e.g., a feedlot or a municipal waste disposal plant), there may be minimal conflict, and existing problems, such as odor, may actually be alleviated. On the other hand, an entirely new ethanol production facility proposed for location in an urban area may create numerous land-use conflicts associated with zoning restrictions, traffic congestion, odor from feedstock storage areas, etc.

In rural areas, one of the most likely land-use conflicts to arise is the siting of a proposed facility on high-quality farmland or within a 100-yr floodplain. Federal land-use policy states the goals of preserving prime and unique farmlands (CEQ 1976, CEQ 1980), and Executive Orders 11988 and 11990 (1977a,b) instruct federal agencies whenever possible to avoid taking actions that would affect floodplains and wetlands. State and local land-use policies may invoke similar restrictions. Issues such as siting a facility on prime farmlands or on a floodplain may not appear to be significant for an individual project but may become highly significant when considered in the context of other developments within the region.

Background information on the site and the region should be carefully evaluated to identify possible land-use conflicts. For any 
land-use conflict identified, the following information should be provided:

- identification of the potential land-use conflict;

- a detailed description of current land-use and zoning or other land-use restrictions relevant to the issue under consideration;

- an evaluation of unique values associated with current land-use (e.g., prime farmland, extensive wetland areas, or historic sites);

- a detailed evaluation of the impacts on land use and mitigation measures to be applied for the proposed project; and

- cumulative impacts of development on the land use in question for the entire region.

\subsubsection{Atmospheric Emissions}

Atmospheric emissions from fuel ethanol production may originate either from the production process itself (including the storage, handling, and initial processing of the feedstock) or from the power plant used to generate process heat. The largest quantities of atmospheric emissions are likely to be released during the production of process heat.

The types of emissions that are released during the production process include particulates, sulfur dioxide, hydrocarbons, carbon monoxide, carbon dioxide, drying chemicals (e.g., ethyl ether), and nitrogen oxides. Of these emissions, particulates and carbon dioxide account for the bulk of the materials emitted. Particulate emissions arise mainly from dust that is generated during the handling of grain and usually are readily controlled by the use of cyclones or baghouses. Large volumes of carbon dioxide produced during fermentation are usually vented to the atmosphere but could be captured and sold as a by-product.

Power plant operations will most likely release the largest quantities of emissions from the facility and will probably be subject 
to best available control technology (BACT) or lowest achievable emission rate (LAER) restrictions in the permitting process. Control of sulfur dioxide and particulates using flue-gas desulfurization systems and electrostatic precipitators, respectively, will be required for coal plants and for some other fuels. Nitrogen oxide emissions may be high for coal plants and for biomass fuels and may present a problem because the technology for $\mathrm{NO}_{x}$ control is not well advanced.

All the information gathered on atmospheric emissions for both the periods of construction and operations should be reviewed, and an evaluation of the types, levels, and impacts of these emissions should be presented. The following information should be presented or referenced:

- types and quantities of fuels to be used;

- anticipated types and levels of emissions (shown separately for the production process and the power plant);

- permit requirements that limit emission levels and the types of pollution control equipment that can be used;

- identification of uncertainties associated with emission levels such as sporadic episodes of high emission levels resulting from poorly controlled combustion;

- description and analysis of emissions associated with the use of novel energy sources (e.g., municipal solid wastes); and

- types of pollution control equipment (e.g., baghouses, electrostatic precipitators, or flue gas desulfurization equipment) that will be used to control specific types of emissions.

\subsubsection{Stillage Use or Disposal}

Stillage consists of unfermentable solids derived from several steps in the production process. A fuel ethanol plant will produce large quantities of stillage that must be either used as a by-product or handled as a waste disposal problem. Potential uses for stillage include (1) feeding it as is to livestock, (2) drying it to produce 
distillers' dried grains (DDG) or other by-products, which can then be used as a livestock feed, and (3) applying it as an amendment to agricultural soils. These potential uses of stillage are limited by (1) the nutritive value of the stillage (i.e., the nutritive value varies with the type of feedstock used); (2) the short storage life of unprocessed, whole stillage; (3) the requirements for and availability of energy for drying; and (4) the market demand for the by-product produced.

Wet-milling is an elaborate and sophisticated feedstock processing technique that produces a wide variety of by-products including corn sweetener, 0il, fiber, and high protein animal feed. The wet-milling of corn may be adopted by large-scale facilities to allow them to shift from production of alcohol to production of corn syrup products as the market demands. Use of this process may confer greater economic stability on the industry, but also increases capital and processing costs. By producing a greater variety of by-products, the amount of stillage produced may be reduced.

If stillage marketing should not prove to be feasible for economic or other reasons, disposal of large amounts of stillage may be required (Sect. 7.3.4). Potential issues associated with waste disposal include odor problems, soil acidification from land spreading, pollution of surface and groundwaters, and overloading of municipal wastewater systems. Although adequate technology exists to control problems that may arise in stillage handling, economic factors may preclude universal application of this technology.

The environmental analysis should include the following information:

- data on the types and quantities of stillage that will be produced;

- plans for using the stillage as a by-product (including the types of by-products being produced, requirements for processing, handling, and storing the by-products, and the market available for the by-products); 
- plans for disposing of stillage that cannot be marketed, including contingency plans for disposing of spoiled or excess stillage if normal avenues for marketing are unavailable; and

- impacts associated with the storage, handling, transport, and disposal of stillage.

\subsubsection{Waste Water Discharges}

Miscellaneous liquid wastes produced in alcohol production include domestic sewage, wash water from equipment cleaning, and occasional bad batches of mash. In addition, if it is necessary to dispose of large amounts of stillage (Sect. 7.3.3), this stillage will become a major waste stream.

While most wastewaters can be handled conventionally (i.e., discharged to sewers, septic tanks, or drain fields), a spoiled batch would contain even greater biochemical oxygen demand (BOD) loadings than an equal volume of stillage. Disposal methods such as lagooning or land spreading would then be required. Unused stillage and wastewaters may be mixed to form a single waste stream. 0ther sources of waste from a fuel ethanol operation that should be considered include runoff from storage and waste disposal areas (e.g., coal storage piles or ash disposal areas).

The wastewaters resulting from ethanol production will vary with the feedstock and the by-product recovery practices used. Raw waste streams may include whole stillage, thin stillage left after dewatering the wet distiller's grains, and condensate from evaporators. Partially treated stillage effluents will also be added to the waste stream.

Wastewaters from fermentation can have very high levels of BOD, acidity, and suspended solids (Chadwick and Schroeder 1973, Brown et a1. 1976). Wastewater streams may be generated by stillage dewatering, by-product drying, or other processes. These streams may be recycled and used for mash preparation in some operations but otherwise would require disposal. High BOD levels from dissolved organic matter such as traces of ethanol and acetic acid would occur in these streams. The condensate from evaporators may contain volatile organic matter and 
have a BOD in excess of $5000 \mathrm{mg} / \mathrm{L}$ (Winston 1980). The principal methods available for treating such waste streams include anaerobic digestion, aerobic treatment, and land spreading (Sect. 7.3.3).

\subsubsection{Anaerboic digestion}

Anaerboic digestion is feasible for wastewaters that have very large (greater than $5000 \mathrm{mg} / \mathrm{L}$ ) oxygen demands (Joyce et al. 1977). As with digestion of sewage sludge, methane can be economically generated from these wastewaters. About 25 volumes of gas are produced for every volume of wastewater treated, although large tanks are needed due to the long retention times (8-40 d) (Joyce et al. 1977). Anaerobic digestion can also be accomplished in lagoons, but this practice requires a sizable commitment of land and may involve odor problems. Although the effluent from digestion has a significantly reduced $B O D$, it is still too high for discharge to streams or municipal sewers, and land treatment or further aerobic treatment is required.

\subsubsection{Aerobic treatment}

Most wastewaters from beverage distilleries are treated aerobically using lagoons, activated sludge processes, trickling filters, and other standard procedures. Distillery wastewaters are readily degradable, although providing sufficient oxygen can be difficult for high strength wastewaters.

\subsubsection{Land spreading}

Stillage and distillery wastewaters can be disposed of by land spreading where land is available (Chadwick and Schroeder 1973). Stillage can be a valuable soil amendment since it adds high levels of organic matter and potassium. It contains little nitrogen, however, and its use may increase nitrogen fertilizer requirements. Severe odor problems can result from land spreading (Winston 1980). Use of a sludge plow that injects material $15-30 \mathrm{~cm}(6-12$ in) below the surface has been suggested to minimize odor problems. 
Stillage with a low pH can be successfully applied to soils when limestone is added to neutralize excess acidity (Winston 1980). Lack of neutralization of low pH liquid effluents may, however, inhibit the growth of crops and soil organisms. Neutralization to a pH of 6 to 8 minimizes adverse disposal effects as well as corrosiveness to process equipment (U.S. EPA 1980).

The following information should be provided:

- identification and characterization of wastewater streams;

- plans for treatment of wastewater streams, including contingency plans for disposal of spoiled batches;

- description of the existing condition of the receiving system based on an expansion of general baseline information; and

- an analysis of the impacts on the receiving system and any other affected 1 and or water body.

\subsubsection{Socioeconomics}

The type and severity of immediate socioeconomic impacts will be related directly to the size of the work force required for construction and operation and the available pool of workers. The most significant impacts should be anticipated for large facilities located in rural areas where the available labor force is small and services to support in-moving workers and their families are limited. For large-scale facilities, where significant socioeconomic impacts may occur, the following points should be addressed:

- impacts on services, such as police and fire protection, education, housing, medical care, and especially water and sewage facilities;

- the community's ability, through aid from the project's proponents, taxation, grants, or other mechanisms, to mitigate any adverse impacts; and

- in cases where the intrusion creates "boomtown" conditions, changes in the economic and political base of the area, as well as effects on such factors as lifestyle, mental health and crime. 
In addition, some note should be taken of the legal requirements for ethanol production, including the Bureau of Alcohol, Tobacco, and Firearms alcohol fuel producers (AFP) permit. Security measures to prevent illegal uses of ethanol produced should also be considered.

\subsubsection{Health and Safety}

As with any industrial or farm operation, ethanol production involves risks and hazards to health and safety. These are categorized somewhat arbitrarily as material hazards and process hazards. In general the hazards of ethanol production are relatively minor, especially when compared to large industrial operations such as producing synfuels from coals.

Materials and compounds that may be hazardous include ethanol, denaturants, dehydrating agents, chemicals for adjusting $\mathrm{pH}$, and grain dust. Many of these substances carry the risk of fire or explosion, while some are toxic or detrimental to human health.

Table 17 provides hazard data on several organic compounds that may be used. Flash point, vapor pressure, and lower flammability limit indicate fire risk. Ether is the most available volatile material, but ether, benzene, and gasoline all have high explosive potential. Ethyl and methyl alcohols involve significant risks of fire, but they are somewhat less explosive than ether, benzene, and gasoline. Ethylene glycol, which is commonly used as antifreeze, is nonflammable and less toxic than the other materials. The "threshold limit values" refer to airborne concentrations and represent levels believed to be safe for occupational exposure. Although the compounds listed in Table 17 vary in their toxicity, all except ethylene glycol can cause poisoning and death through inhalation of the vapors at high concentrations. Symptoms resulting from high exposures include drowsiness, dizziness, stupor, and unconsciousness. Chronic exposure can also be detrimental, especially with benzene, a suspected human carcinogen.

The chemicals used to adjust $\mathrm{pH}$ include sodium hydroxide and sulfuric acid. In concentrated form these substances are caustic. Contact with skin can cause burns, while inhalation of vapors or mist 
Table 17. Characteristics of chemical substances possibly handled in ethanol production

\begin{tabular}{|c|c|c|c|c|c|c|}
\hline Compound & Uses & $\begin{array}{c}\text { Flash pointa } \\
{ }^{\circ} \mathrm{C}\end{array}$ & $\begin{array}{l}\text { Vapor pressure } \\
\left(\mathrm{mm} \mathrm{Hg} \text { at } 25^{\circ} \mathrm{C}\right)\end{array}$ & $\begin{array}{c}\text { Lower } \\
\text { flammability } \\
\text { limita } \\
(\% \text { volume } \\
\text { in air) }\end{array}$ & $\begin{array}{c}\text { Threshold } \\
\text { limit valueb } \\
\text { (ppm) }\end{array}$ & $\begin{array}{l}\text { Toxicity } \\
\text { ratingc }\end{array}$ \\
\hline $\begin{array}{l}\text { Ethy } 1 \\
\text { alcohol }\end{array}$ & Motor fuel & $\begin{array}{l}18(95 \%) \\
14(100 \%)\end{array}$ & 50 & 3.28 & 1000 & $\begin{array}{l}\text { Moderately } \\
\text { toxic }\end{array}$ \\
\hline $\begin{array}{l}\text { Methyl } \\
\text { alcohol }\end{array}$ & $\begin{array}{l}\text { Denaturant, } \\
\text { motor fuel }\end{array}$ & 12 & 125 & 6.72 & 200 & $\begin{array}{l}\text { Moderately } \\
\text { toxic }\end{array}$ \\
\hline $\begin{array}{r}\text { Ethylene } \\
\text { glycol }\end{array}$ & $\begin{array}{l}\text { Dehydrating } \\
\text { agent }\end{array}$ & 116 & $\begin{array}{l}0.06 \text { at } \\
20^{\circ} \mathrm{C}\end{array}$ & - & 100 & $\begin{array}{l}\text { Slightly } \\
\text { toxic }\end{array}$ \\
\hline $\begin{array}{l}\text { Ethy } 1 \\
\text { ether }\end{array}$ & $\begin{array}{l}\text { Dehydrating } \\
\text { agent }\end{array}$ & -40 & $\begin{array}{l}439 \text { at } \\
20^{\circ} \mathrm{C}\end{array}$ & 1.9 & 400 & $\begin{array}{l}\text { Moderately } \\
\text { toxic }\end{array}$ \\
\hline Benzene & $\begin{array}{l}\text { Dehydrating } \\
\text { agent }\end{array}$ & -11 & 100 & 1.35 & 25 & $\begin{array}{l}\text { Moderately } \\
\text { toxic }\end{array}$ \\
\hline $\begin{array}{l}\text { Gasolined } \\
\text { (n-octane) }\end{array}$ & $\begin{array}{l}\text { Dehydrating } \\
\text { agent } \\
\text { denaturant }\end{array}$ & 13 & $\begin{array}{l}10.5 \mathrm{at} \\
20^{\circ} \mathrm{C}\end{array}$ & 0.96 & $500^{d}$ & $-d$ \\
\hline
\end{tabular}

Data from: Patty (1963).

Data from: Fairchild (1977).

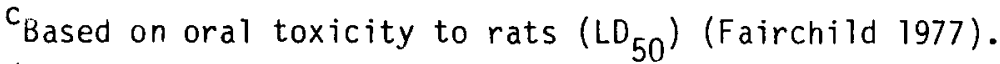

dGasoline is a complex and variable mixture of aliphatic and aromatic hydrocarbons. Data for n-octane indicate flammability, while toxicological characteristics are dependent on content of aromatics, especially benzene. 
can damage Tungs. Proper equipment and handling procedures are required for safe use. Small fermentation operations can use more dilute reagents, such as a slurry of hydrated lime, to adjust $\mathrm{pH}$.

Reports of particulate emissions from handling grain from elevator operations and from drying spent grain range from 1.5 to $2.5 \mathrm{~kg} / \mathrm{Mg}$ grain handled, respectively (U.S. EPA 1977). Assuming that $2.7 \mathrm{~kg}$ of grain are needed to produce a liter of alcohol $(2.5 \mathrm{gal} / \mathrm{bu})$, total particulate emissions could equal $10.7 \mathrm{~g} / \mathrm{L}$ of alcohol produced.

Fugitive emissions from production and handling of alcohol might equal as much as $0.25 \%$ of the volume produced. Such emissions would be greater if ethanol and gasoline are mixed at the production site.

Ethanol production will generate risks from the routine handling of potentially hazardous materials and use of steam for heat. Table 18 lists hazards and appropriate precautions. An additional hazard is the conception by workers that "it's only ethanol" because they drink ethanol. This familiarity with ethanol results in worker failure to realize that it is toxic and should be handled with care (Segnar 1981).

The environmental analysis should include the following information and analysis in the health and safety section:

- identification of material and process hazards associated with the proposed project;

- evaluation of the degree of risk; and

- plans for controlling and minimizing the risks of exposure and accidents. 
Table 18. Ethanol plant hazards (SEIDB 1980)

Hazards

Precautions

Overpressurization; explosion of boiler

Contact burns from steam lines

Ignition of ethanol leaks/fumes or grain dust
Regularly maintain and check safety boiler "pop" valves that are set to relieve pressure when it exceeds the maximum safe pressure of the boiler or delivery lines.

Strictly adher to boiler manufacturer's operating procedure.

If boiler pressure exceeds $1.4 \times 10^{5} \mathrm{~Pa}$ (20 psi), require ASME boiler operator attendance during boiler operation.

Insulate all steam delivery lines.

If electric pump motors are used, use fully enclosed explosion-proof motors.

(Option) Use hydraulic pump drives; main hydraulic pump and reservoir should be physically isolated from ethanol tanks, dehydration section, distillation columns and condenser.

Fully ground all equipment to prevent static electricity build-up.

Never smoke or strike matches around ethanol tanks, dehydration section, distillation columns, or condenser.

Never use metal grinders, cutting torches, welders, etc., around systems or equipment containing ethanol. Flush and vent all vessels prior to performing any of these operations. 
Table 18. (continued)

\begin{tabular}{|c|c|}
\hline Hazards & Precautions \\
\hline $\begin{array}{l}\text { Scalding from steam } \\
\text { gasket leaks }\end{array}$ & $\begin{array}{l}\text { Place baffles around flanges to direct } \\
\text { steam jets away from operating areas. } \\
\text { (Option) Use welded joints in all steam } \\
\text { delivery lines. }\end{array}$ \\
\hline \multirow[t]{7}{*}{ Handling acids/bases } & $\begin{array}{l}\text { Never breathe the fumes of concentrated } \\
\text { acids or bases. } \\
\text { Never store concentrated acids in carbon } \\
\text { steel containers. }\end{array}$ \\
\hline & $\begin{array}{l}\text { Mix or dilute acids and bases slowly, } \\
\text { allow heat of mixing to dissipate. }\end{array}$ \\
\hline & $\begin{array}{l}\text { Immediately flush skin exposed to acid } \\
\text { or base with copious quantities of water. }\end{array}$ \\
\hline & $\begin{array}{l}\text { Wear goggles whenever handling concen- } \\
\text { trated acids or bases; flush eyes with } \\
\text { water and immediately call physician if } \\
\text { any gets in eyes. }\end{array}$ \\
\hline & $\begin{array}{l}\text { Do not store acids or bases over work } \\
\text { areas or equipment. }\end{array}$ \\
\hline & $\begin{array}{l}\text { Do not carry acids or bases in open } \\
\text { buckets. }\end{array}$ \\
\hline & $\begin{array}{l}\text { Select proper materials of construction } \\
\text { for all acid or base storage containers, } \\
\text { delivery aids, valves, etc. }\end{array}$ \\
\hline Suffocation & $\begin{array}{l}\text { Never enter the grain bins, fermenters, } \\
\text { beer well, or stillage tanks unless they } \\
\text { are properly vented. }\end{array}$ \\
\hline
\end{tabular}




\subsection{REFERENCES}

American Society for Testing and Materials (ASTM). 1969. Manual on Water, 3rd edition. ASTM Special Pub1. No. 422. Committee D-19 on Water, American Society for Testing and Materials, Philadelphia, Pennsylvania.

Anthony, W. B. 1979. Agricultural considerations of distillery feedstocks and the use of distillers grain for animal feed. pp. 57-72. IN B. J. Schroer and R. L. King (eds.), Production and Use of Fermentation Alcohol in the Southeast. Conference Proceedings, University of Alabama, Huntsville, Alabama.

Braunstein, H. M., P. Kanciruk, R. D. Roop, F. E. Sharples, J. S. Tatum, and K. M. Oakes. 1981. Biomass Energy Systems and the Environment. Pergamon Press, New York.

Brown, D., R. Mckay, and W. Weir. 1976. Some problems associated with the treatment of effluents from malt whiskey distilleries. Prog. Water Technol. 8(2/3):291-294.

Chadwick, T. H., and E. D. Schroeder. 1973. Characterization and treat-ability of pomace stillage. J. Water Pollut. Control Fed. $45(9): 1978-1984$.

Council on Environmental Quality (CEQ). 1977. Memorandum for heads of agencies: Analysis of impacts on prime and unique farmland in environmental impact statements. Appendix $F$. IN Council on Environmental Quality, Environmental Quality: the Eighth Annual Report of the Council on Environmental Quality. Washington, D.C.

Council on Environmental Quality (CEQ). 1980. Analysis of impacts on prime or unique agricultural lands in implementing the National Environmental Policy Act. Fed. Regist. 45:59189.

Elmore, J. L., E. D. Waits, F. E. Sharples, S. Carnes, M. Schweitzer, and J. F. McBrayer. 1982. Generic environmental assessment report for conventional fuel alcohol plants. ORNL/TM-7993. Oak Ridge National Laboratory, Oak Ridge, Tennessee. $126 \mathrm{pp}$.

Executive Order No. 11988. 1977a. Floodplain management. Fed. Regist. $42: 26951$.

Executive Order No. 11990. 1977b. Protection of wetlands. Fed. Regist. 42:26961.

Fairchild, E. J. (ed.). 1977. Registry of Toxic Effects of Chemical Substances. National Institute for 0ccupational Health, U.S. Department of Health, Education and Welfare, Washington, D.C. 
Gleason, M. N., R. E. Gosselin, H. C. Hodge, and R. P. Smith. 1969. Clinical Toxicology of Commercial Products, 3rd ed. Williams and Wilkins Co., Baltimore, Maryland.

Joyce, M. E., J. F. Schiaef, M. W. Cochrane, and K. A. Dostal. 1977. State of the art: Wastewater management in the beverage industry. EPA-600/2-77-048. U.S. Environmental Protection Agency, Industrial Environmental Research Laboratory, Cincinnati, Ohio.

McKee, J. E., and H. W. Wolf (eds.). 1963. Water quality criteria. Publ. No. 3-A. California Water Quality Control Board, Sacramento, California.

Muller Associates, Inc. 1981. Alcohol from biomass: State-ofknowledge survey of environmental, health, and safety aspects. Office of Environmental Programs, U.S. Department of Energy, Washington, D.C.

Patty, F. A. (ed.). 1963. Industrial Hygiene and Toxicology, 2nd ed. John Wiley and Sons, New York.

Segnar, A. M. 1981. Operations experience at solvent ethanol facilities. pp. 279-285. IN M. S. Salk, F. E. Sharples, and J. F. McBrayer (eds.), Proc., Moonshine to Motor Fuel. Conf-810303. Oak Ridge National Laboratory, Oak Ridge, Tennessee.

Soil Conservation Service (SCS). 1977. USDA Potential Cropland Study. SCS Statistical Bulletin 578. U.S. Department of Agriculture, Washington, D.C.

Solar Energy Information Data Bank (SEIDB). 1980. Fuel from farms - a guide to small-scale ethanol production. SERI/SP-451-519. Solar Energy Research Institute, Golden, Colarodo.

U.S. Department of Agriculture (USDA). 1978. Agricultural Statistics. U.S. Government Printing Office, Washington, D.C.

Washington, D.C.

1980. Small-scale fuel alcohols production.

U.S. Environmental Protection Agency (U.S. EPA). 1977. Compilation of Air Emission Factors, 3rd edition. AP-42. Research Triangle Park, North Carolina.

1980. Testing and evaluation of on-farm alcohol production facilities. Industrial Environmental Research Laboratories, Cincinnati, Ohio. 
Winston, S. J. 1980. Stillage treatment technologies. Appendix B. IN Gasohol Task Group. Environmental Impacts of Accelerated Gasohol Production: Preliminary Analysis. Energy Environmental Systems Division, Argonne National Laboratory, Argonne, Illinois. 
APPENDIX A

DESCRIPTION OF THE AFFECTED ENVIRONMENT

The assessment of project-related environmental impacts must be based in part on baseline data that describe site conditions before any project activities are initiated. Baseline information for the site and its immediate vicinity is often readily available from land owners and government agencies involved with resource management (e.g., U.S. Fish and Wildlife Service, Soil Conservation Service, and the Environmental Protection Agency). Often a general description of a site can be developed on the basis of such existing information plus a visit to the site to confirm that the available information is relevant to the site under consideration.

A major concern of government agencies in assembling a baseline description is to avoid the needless collection of detailed site data which will not affect the final decision on whether or not to approve the project. To determine what information is necessary, the general categories of environmental concerns summarized in Table A.l should be reviewed for each project. The amount of detail needed for each category will vary with the type of project, the characteristics of the site, the anticipated environmental impacts, and the type of decision that is being considered. For example, if the agency decision is on final project approval and the information will be used as a basis for an environmental impact statement, more specific information may be needed than if the decision is to determine whether significant impacts are likely to occur and the information will be used as a basis for an environmental assessment.

At the minimum, the affected environment section should present a general description of the major environmental features of the site and a more detailed description of those features that are likely to be affected by project activities. A well-prepared section on the affected environment will provide the necessary background for the section on potentially significant issues and will assist in focusing the latter section on the evaluation of impacts. 
Table A.1. Information needed for describing the existing environment of the site and its surroundings

Category

1. Land use and zoning

2. Floodplains and wet lands

3. Prime and unique farmlands

4. Cultural and aesthetic resources

5. Geology

6. Terrestrial and logy

7. Endangered and threatened species

Type of information

Possible sources of information

Maps and tables showing present land use on the site and surrounding area; land ownership; regional, state, and local land-use plans and controls pertinent to the sit and surrounding area.

Maps showing the locations of the 100- and 500-year floodplains and onsite wet lands; table showing onsite area (hectares) for each floodplain or wet land; descripand abundance of each wet land type.

Soils map of the site; description of onsite soil type; area (hectares) of soil on the site that is classified as prime or unique farmland.

Location and description of cultural and aesthetic resources on or in the vicinity of the site, including historic and archaeological sites, Indian tribal resources, scenic, and other desthetic resources.

Geological bedrock, and surface formations; topography; location and description of potential geologic hazards, including consideration of slope stability, mass movement, faults, subsidence, settlement, liquefaction, and volcanic activity; economically recoverable energy and mineral resources.

Map and description of vegetation types on the site; wildife species and habitats; presence of rare, unique, or important ecological comunities or habitats; descripin water bodies.

Lists and descriptions of federal and state endangered, threatened, rare, and protected species and their critical habitat present in the region of the site; observations and reports of such species and habitats on the site or on other areas to be affected by the project. Formal consultation with the U.S. Fish and Wildlife Service is the responsibility of the federal action agency; an applicant, however, should provide any information obtained from initial contacts, including copies of any correspondence concerning the project.
State, regional, and local planning comissions; state agencies, such as Departments of Conservation, Fish and Game, and Parks; federal agencies, such as U.S. Geological survey, Soil Conservation Service, Bureau of Land Management, Forest Service; onsite servations.

FEMA Flood Insurance Rate Maps and Flood Hazard Boundary Maps;

life Service National wetlands Inventory; ons. S. Fish and Wild

U.S. Soil Conservation Service - contact state soil conservationist and local soil conservation of $f$ ice; state agricultural colleges.

State historic preservation office; National Register of Historic Piaces; National Register of Natural Landmarks; U.S. Bureau of Indian Affairs; local tribal headquarters; onsite observations.

U.S. Geological Survey national distribution center, Reston, Virginia; USGS depositories of publications at state land grant universities; state geologist; USGS topographic and land-use maps; onsite observations.

Ecologists and other biologists at local and state colleges and universities; private environmental and conservation organizaobservations, US. Fish and Wild ife service habitat; onsite procedures.

Federal list of endangered and threatened species, published annually and updated as needed in the Federal Register; state by state departments of fish and game or conservation; local chapters of organizations concerned with enviroment and conservation (e.g., the National Audubon Society or the National Wildlife Federation). 
Table A.1. Continued

Table A.l. Continued

Category

Type of information

Possible sources of information

U.S. Geological Survey; U.S. Environmental Protection Agency; delegated state agencies for administering EPA permit programs; state geological survey; geologists and hydrologists at local and state colleges and universities; National Waterwell Association.

affected by the project, including aquifer characteris tics, flow system characteristics, competing water use sole-source aquifer.

9. Surface water

Description of surface water features that will be affected by the project; a map showing the drainage pat tern of the site and its surroundings and ons ite water bodies; data on water availability and water quality of affected water bodies.

10. Climate and air quality

11. Noise

12. Soc ioeconomics
Climatic parameters, such as, average temperatures, relative humidity, precipitation, wind direction and speed, wind stability classes, mixing heights, fog occurricane frequency), identification of air quality control regions in which the site is located and those affected by emissions from the facility: description of the att ainment or nonattainment status for the criteria pollutants; description of present ambient air quality; State Implementation Plan (SIP) restrictions; location of any Class area (nondegradation areas, e.g., wilderness areas or national parks) affected by project emissions; discuss ion of trends in pollutant levels over time where data on air quality is readily available.

Existing ambient background noise levels on the site and in the vicinity; major existing or planned noise sources and sensitive receptors.

Definition of socioeconomic impact region; current and projected population and relevant demographic characteristics; local governent revenues, expenditures, and revenue-sharing arrangements; current and projected housing capacity; current and planned public service capacity (water, sewer, transportation, police, fire, health, education, and welfare); economic structure and labor force characteristics; local government characteristics; loca organizations and interest groups; social structure and life styles; local support or opposition to the proposed project.
USGS topographic maps; aerial photographs; comprehensive data bases such as water Resources Abstracts, WATSTORE, NAWDEX, and STORET, state and federal agencies responsibie for permitting, including U.S. Enviromiental Protection Agency, U.S. Army Corps of Engineers, and delegated state agencies; onsite observations.

National Weather Service or Federal Aviation Administration stations; National Climatic Center, Asheville, North Carolina; local airports, E.S. Environinental Protection Agency or state industrial or research facilities that collect climatic or air quality data.

Onsite measurements; contacts with local and state agencies examination of area maps.

U.S. Bureau of Census publications; pertinent government and private reports; academic reports - especially by local institutions, local newspapers, interviews with government officials, researchers, and interested parties; inspection of the site and region. 
192 


\section{APPENDIX B}

OUTLINE FOR AN ENVIRONMENTAL ANALYSIS

This appendix describes one way of organizing an environmental analysis being prepared for submission to a government agency. Many agencies have specific format and information requirements. The organization presented here is generally compatible with these types of requirements. The amount of information that should be included in each section described below will depend on the type and size of the project and the significance of the anticipated environmental impacts.

\section{B. 1 SUMMARY}

A summary of the information contained in the environmental analysis should include a brief description of:

- the type of project,

- the processes to be used,

- principal emissions and discharges,

- major features of the site and other affected areas,

- the impacts that have been identified, and

- plans for mitigation and monitoring.

\section{B.2 DESCRIPTION OF THE PROPOSED PROJECT}

This section should provide sufficient information on the physical plant, the process, and the waste streams (atmospheric emissions, liquid effluents, and solid wastes) to evaluate the environmental, health, safety, and socioeconomic impacts of the proposed project. Both onsite and offsite facilities and activities should be described.

\section{B.2.1 Purpose and Need}

The environmental analysis should discuss the purpose of the project, the types of products and by-products produced, and the 
intended market for the product. The type of government involvement should be clearly stated, and, in cases where an applicant is seeking financial support or approval, alternatives available if no support were to be provided should be discussed.

\section{B.2.2 Site Description and Location}

The location of the site and its geographic context should be described. A general map at the state and/or regional level showing the location of the site and other affected areas should be provided. Also, United States Geological Survey (USGS) topographic quadrangle maps (preferably $7.5 \mathrm{~min}$. scale) should be included showing the boundaries of the site and other affected areas.

\section{B.2.3 Plant Description and Site Plan}

The environmental analysis should describe the facilities that are planned for the proposed project. In addition to the proposed facilities, existing facilities on the site, offsite ancillary facilities that will be required by the proposed project, and facilities that are included in any plans for future expansion should be described. For example, the following types of facilities should be described for a project that includes surface mining, separation, and upgrading operations:

- well field or surface mine;

- separation facilities;

- fluid coker;

- nitrogen generator;

- amine plant;

- hydrogen plant;

- hydrotreaters;

- Claus plant; 
- $\quad$ steam and power generation plant;

- relief and blowdown system;

- tankage and interconnecting piping;

- raw and cooling water distribution systems;

- cooling towers and recycle water facilities;

- transmission lines, pipelines, access roads, and rail spurs;

- ash handling and disposal facilities;

- $\quad$ settling ponds and other waste disposal facilities;

- sewage treatment facilities; and

- fire protection facilities.

A site plan should be provided showing the layout of proposed facilities associated with construction and operation.

\section{B.2.4 Construction}

Resources needed for constructing the proposed project should be described, including requirements for land, materials, water, labor supply, and community services (e.g., water treatment facilities, sanitary landfills, and roads). A diagram of the site showing the location of all construction activities (e.g., lay-down areas or construction waste disposal sites) and a proposed schedule showing the major phases of construction should be provided.

\section{B.2.5 Operation}

A description should be included of materials, energy, and manpower required by the proposed project; the process flow; and the products, by-products, and waste streams produced by facility operations. 


\section{B.2.5.1 Resources}

Resources needed for plant operation should be described, including:

- sources, amounts, and transportation of feedstocks;

- energy sources, water, and other materials (e.g., catalysts or injection fluids);

- labor requirements disaggregated by craft;

- labor availability and use; and

- availability of community services.

\section{B.2.5.2 Plant design and process flow}

The basic plant design and process flow should be described, giving an overview of the entire operation and emphasizing those steps in the process where inputs are required and effluents generated. Options available for such process steps as pollution abatement or well injection should be described briefly. Process flow diagrams should be included.

\section{B.2.5.3 Wastes and effluents}

Solid, liquid, and gaseous effluents and wastes should be characterized in terms of their composition and the quantities produced. Special emphasis should be given to toxic and hazardous substances. Plans for treatment and/or disposal should be described.

\section{B.2.5.4 Schedule of operations}

A schedule of operations that includes both the initial shakedown period and normal operations should be provided. Any future plans for expanding or reducing operations should be discussed.

\section{B.2.5.5 Planned mitigation and monitoring}

Mitigation measures (including reclamation plans) and monitoring programs that are part of the proposed project should be described. 
This section should collate and summarize specific mitigation measures and monitoring programs that have been developed for each potentially significant issue and should also include a list of standard good management practices that will be implemented. Planned mitigation measures that will be implemented to minimize or avoid adverse impacts during construction, operation, and decommissioning should be described. In addition, a monitoring program should be presented showing the location of monitoring stations and the types and frequencies of data to be collected for each phase of project activity (i.e., preconstruction, construction, operation, and decommissioning). The environmental analysis should indicate how the monitoring programs during construction and operation are related and how they differ. A discussion should also be included of how the monitoring data will be evaluated and used and how permit monitoring requirements will be integrated into the overall program.

\section{B.2.6 Permits and Approvals}

An environmental analysis should list, describe, and discuss the status of permits, licenses, and approvals required by federal, state, regional, and local agencies and Indian tribes. A list of agencies and persons contacted should also be provided.

\section{B.3. ALTERNATIVES}

Comparison of the environmental impacts associated with project alternatives, including the proposed project, is usually an important part of an environmental analysis. The range of alternatives to be considered and the extent of the analyses required depend to some extent on previously conducted studies that may include generic or programmatic alternatives such as the use of alternative energy resources. If such studies are available, they may be incorporated by reference into the environmental analysis.

The analysis of alternatives should discuss those alternatives considered during project planning (including the no-action alternative), the environmental impacts associated with each 
alternative, and the selection process used to choose the proposed site and process design.

\section{B.4. THE AFFECTED ENVIRONMENT}

This section of an environmental analysis should describe the environment of the site and the region in sufficient detail to provide an overview of the environment that will be affected by the proposed project and general background information for evaluating potentially significant environmental impacts (Appendix A). The information prepared for this section should also be used to ensure that all potential environmental impacts have been identified and adequately evaluated.

\section{B.5. POTENTIALLY SIGNIFICANT ISSUES}

Each potentially significant issue that has been determined to be relevant to a particular project should be discussed in detail in this section. Baseline information should be presented in sufficient detail to permit an independent evaluation of the significance of project-related impacts by the agency to which the environmental analysis is submitted. An analysis of impacts should be presented, including an evaluation of their significance and a discussion of mitigation measures planned for minimizing adverse effects. Methods used in collecting and analyzing the data should be described. Lengthy discussions of methodology should be relegated to an appendix. Data summaries are generally appropriate for this section, but the actual data should be either incorporated into an appendix or assembled in a separate document that $c a n$ be made available on request for agency review. 